\title{
The
}

University

of Chicago

Law Review

\section{Alternatives to Zoning: Covenants, Nuisance Rules, and Fines as Land Use Controls*}

\author{
Robert C. Ellickson†
}

I. EXTERNALITIES AND SYSTEMS FOR THEIR INTERNALIZATION $\ldots \ldots \ldots \ldots \ldots \ldots \ldots \ldots$

II. Criteria for Evaluating Land Use Control Systems $\ldots \ldots \ldots \ldots \ldots \ldots \ldots \ldots \ldots .687$

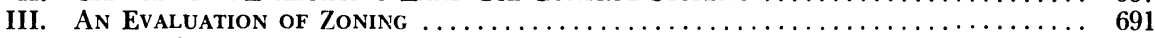

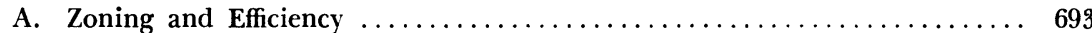

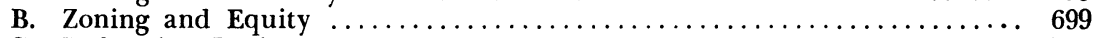

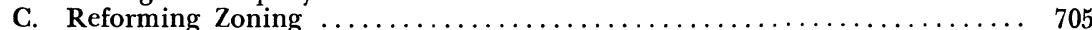

IV. Covenants, Merger, and Other Consensual Systems of Land Use Regulation 711

V. Assigning Rights Among Landowners: A Reformulation of Nuisance Law . . 719

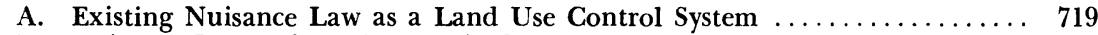

B. Nuisance Law: The Prima Facie Case ......................... 722

1. Assigning Rights to Promote Efficiency: A Preliminary General Rule .. 724

2. Toward a Tripartite System of Internalization: The Unneighborliness

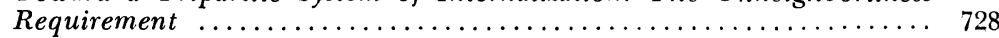

3. Compensable Damage: The Problem of Aesthetics ............. 733

4. Measuring Damage: Bonuses for Consumer Surplus .............. 735

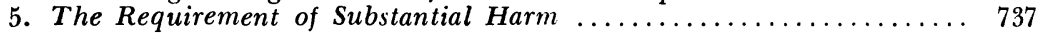

6. Remedies: The Plaintiff's Choice between Damages and Purchasing an

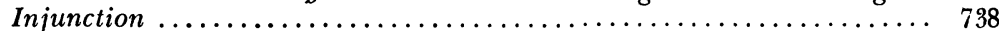

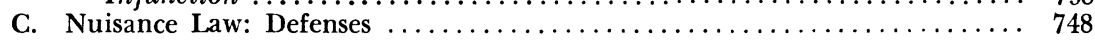

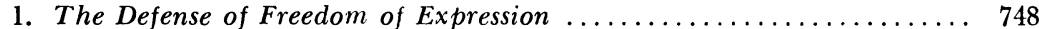

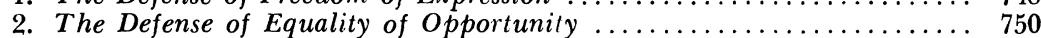

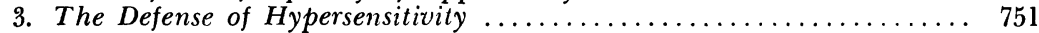

4. The Defense of Failure to Mitigate Damages ................... 758

vi. A Tentative Sketch of a More Privatized System of Land Use Regllation 761

A. The Superiority of Nuisance Law for Localized Harm ............. 762

B. The Necessity of More Collective Internalization Systems for Pervasive

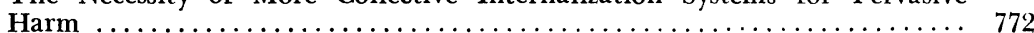

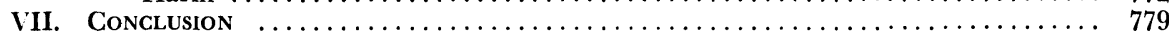

* I am indebted to Bruce L. Ackerman, Alan Axelrod, Scott Bice, Richard Epstein, George Lefcoe, Michael Levine, Richard Posner, and Michael Shapiro for helpful comments on early drafts of this article.

+ Associate Professor of Law, University of Southern California. 
With increasing frequency commentators have been urging greater reliance on the market mechanism to allocate resources in a variety of fields. ${ }^{1}$ There has been relatively little examination, however, of the extent to which decentralized mechanisms can be used to handle the controversial social problem of conflicts among neighboring landowners. ${ }^{2}$ Land development in urban areas is one of the most regulated human activities in the United States. In recent decades, public regulation of urban land has increased sharply in incidence ${ }^{3}$ and severity, ${ }^{4}$ but dissatisfaction with the physical appearance and living arrangements in American cities continues to grow. Despite the evident shortcomings of present public regulatory schemes, even those commentators who propose reliance on the market mechanism in other areas tend to concur with the prevailing view that increased public planning is the most promising guide for the growth of cities. ${ }^{5}$ This article advances a different thesis: that conflicts among neighboring landowners are generally better resolved by systems less centralized than master planning and zoning. ${ }^{6}$

1 The trend is international. See Lindblom, The Rediscovery of the Market, PuBlic INTEREST, Summer, 1966, at 89. Perhaps surprisingly, Ralph Nader is in principle sympathetic: "Hence, our general industrial policy should encourage competition in our economy by minimizing regulation, except when clearly necessary." Green \& Nader, Economic Regulation vs. Competition: Uncle Sam the Monopoly Man, 82 Yale L.J. 871, 883 (1973).

2 The leading articles advocating market-oriented solutions to land use problems include: Coase, The Problem of Social Cost, 3 J. LAw \& Econ. 1 (1960) [hereinafter cited as Coase, Social Cost]; Siegan, Non-Zoning in Houston, 13 J. LAw \& EcoN. 71 (1970) Thereinafter cited as Siegan, Non-Zoning]; Baxter \& Altree, Legal Aspects of Airport Noise, 15 J. LAw \& ECon. 1 (1972); Note, Land Use Control in Metropolitan Areas: The Failure of Zoning and a Proposed Alternative, 45 S. CAL. L. Rev. 335 (1972); Note, An Economic Analysis of Land Use Conflicts, 21 Stan. L. REv. 293 (1969). Siegan has recently expanded his landmark article into a book: B. Siegan, LAND Use Without Zoning (1972). There are a number of leading articles by the economist Otto A. Davis, often with joint authors: Davis \& Whinston, The Economics of Urban Renewal, 26 LAw \& CoNTEMP. ProB. 105 (1961); Davis, Economic Elements in Municipal Zoning Decisions, 39 LAND Econ. 375 (1963); Davis \& Whinston, Economics of Complex Systems: The Case of Municipal Zoning, 17 Kyklos 419 (1964); Davis \& Whinston, On Externalities, Information and the Government-Assisted Invisible Hand, 33 Economica 303 (1966); Crecine, Davis \& Jackson, Urban Property Markets: Some Empirical Results and Their Implications for Municipal Zoning, 10 J. LAw \& Econ. 79 (1967).

3 For statistics on the proliferation of zoning ordinances, see text at notes 34-38 infra.

4 See National Commission on Urban Problems, Building the American City 205-06 (1969) [hereinafter cited as Building the American City].

5 See, e.g., Model Land Development Code (Tent. Drafts No. 2, 1970 and No. 3, 1971); Building the American City, supra note 4; R. Fellmeth, Politics of Land 401-05 (1973); Reps, The Future of American Planning: Requiem or Renaissance?, LAND Use Controls, No. 2, 1967, at 1 .

6 Others, of course, have raised doubts about the wisdom of greater governmental intervention in land markets. See generally sources cited note 2 supra. Among the 
First, the article offers goals for a land use control system. Three major means of control are then evaluated in terms of these goals: (1) mandatory public regulations (zoning), ${ }^{7}$ (2) consensual private agreements (covenants), ${ }^{8}$ and (3) the redefinition of property rights and their private enforcement (nuisance law) ${ }^{9}$ Finally, the article explores how these methods, and others, might be interrelated to produce a more efficient and equitable system for guiding urban growth. ${ }^{10}$ The analytical approach, and the substance of the conclusions, have been heavily influenced by Professor Guido Calabresi's groundbreaking work in analyzing accident law. ${ }^{11}$

\section{EXTERNALities AND SYSTEMS FOR THEIR INTERNALIZATION}

Economists assert that if the market remains free of imperfections, market transactions will optimally allocate scarce resources. They do not maintain that the distribution of these optimally-allocated resources among specific individuals will necessarily be just. If injustices in distribution arise, most economists urge that they be corrected by direct cash transfer payments, rather than through more indirect attempts at redistribution. According to this economic model, optimally efficient patterns of city development would evolve naturally if urban land development markets were to operate free of imperfections; city planning or public land use controls would only make matters worse from an efficiency standpoint. Since market forces would generate the most efficient land use, the basic decision for policy makers would be the distribution of urban pleasures among residents, with adjustments preferably made through cash transfer payments.

most distinguished and persistent of these skeptics are Professors Allison Dunham, e.g., Property, City Planning, and Liberty, in LAw AND LAND 28 (C. Haar ed. 1964) and Friedrich Hayek, e.g., The Constitution OF LiBerTy 340-57 (1960).

7 See text at notes 31-117 infra.

8 See text at notes 118-42 infra.

9 See text at notes 143-268 infra.

10 See text at notes 269-318 infra.

11 The most complete exposition of Professor Calabresi's analytical scheme is THE Cost of Accidents (Student ed., 1970) [hereinafter cited as G. Calabresi, Cost of AcciDENTs]. That work incorporated much of his earlier articles on accident law: Some Thoughts on Risk Distribution and the Law of Torts, 70 YALE L.J. 499 (1961); The Decisions for Accidents: An Approach to Nonfault Allocation of Costs, 78 Harv. L. Rev. 713 (1965); Fault, Accidents and the Wonderful World of Blum and Kalven, 75 YALE L.J. 216 (1965); Transaction Costs, Resource Allocation and Liability Rules-A Comment, $11 \mathrm{~J}$. LAw \& ECoN. 67 (1968). For an artful commentary on the Calabresi approach, see Michelman, Book Review, 80 YALE L.J. 647 (1971) [hereinafter cited as Michelman, Book Review]. The latest from the master are Calabresi \& Melamed, Property Rules, Liability Rules, and Inalienability: One View of the Cathedral, 85 HARv. L. Rev. 1089 (1972) and Calabresi \& Hirschoff, Toward a Test for Strict Liability in Torts, 81 YAle L.J. 1055 (1972). 
Land development markets, however, are not perfect and in reality city development is far from optimal. Economists regularly use land markets to illustrate that where transactions or activities entail "externalities" or "spillovers"- that is, impacts on nonconsenting outsiders -suboptimal resource allocation will often result. Although beneficial externalities can also impair efficient allocation, this article deals primarily with externalities harmful to nonconsenting outsiders. ${ }^{12}$ Welfare economists have urged that harmful externalities be "internalized" to eliminate excessive amounts of nuisance activity. Internalization is said to be accomplished through devices that force a nuisance-maker to bear the true costs of his activity. ${ }^{13}$ Internalization of harmful spillovers in land development often requires some departure from what this article calls a laissez faire distribution of property rights, an imaginary legal world where each landowner can choose to pursue any activity within the boundaries of his parcel without fear of liability to his neighbors or governmental sanction. These departures range from those that are compatible with the continuance of private markets to those that seek to supplant the market mechanism altogether; thus, systems for internalizing harmful spillovers range from relatively decentralized ones that emphasize private ordering to others that are highly collectivized and rely on mandatory decrees. ${ }^{14}$

This article will examine a spectrum of internalization systems as they might apply to a specific land use problem, the location of grocery stores in the Santa Monica Mountains. These mountains, actually a low range of hills never exceeding 2,000 feet in height, divide the City of Los Angeles into roughly two halves, the San Fernando Valley on the north and the Los Angeles Basin on the south. The attractive physical features of the mountains and the views they offer have made them a popular residential area for the wealthy, as indicated by the communities in their foothills (Beverly Hills, Belair, and Pacific Pali-

12 This narrowing of focus should not be construed as a downgrading of the importance of dealing with activities having beneficial spillovers. Devices for increasing the optimality of resource allocation by providing compensation for beneficial spilloversbounties, modifications of the law of unjust enrichment, bonus zoning, and the likedeserve far more attention from scholars and policy makers than they have yet received.

13 The following text is a brief introduction to a spectrum of internalization devices. For a discussion of the extremely difficult issues of identifying and measuring harmful externalities, see text at notes 143-268 infra.

14 This system of categorization follows Michelman's suggestion that regulatory systems be judged by their degree of collectivization of decision making. Michelman questioned Calabresi's dichotomy of "general" and "specific" deterrence systems, corresponding roughly to market systems and public regulatory systems, since that bisection tends to obscure the actual range of gradations of collective action. See Michelman, Book Review, supra note 11 , at $661-66$. 
sades). Virtually all of the buildings in the mountains today are singlefamily detached houses. Most of the people living near the top must drive as long as ten minutes down the mountains to reach the nearest grocery store. Children who live in the mountains obviously cannot walk or bicycle to a store to buy a soft drink, baseball cards, or crayons. In light of the rather high density of houses at the top of the mountains and the severe isolation from other commercial facilities, there is probably sufficient market demand to support a small mom-and-pop or convenience-type grocery store at one of the key intersections of the road that runs along the crest. If such a store were built, however, both the resulting traffic and noise and the unattractiveness of the store might cause some diminution in the value of nearby residences, an apparent example of a harmful externality from a land use activity. This harmful spillover is not internalized to the grocer under existing law since the drop in neighboring property values is borne by the homeowners if the grocery is normally operated..$^{15}$

One option for handling externalities from unneighborly land uses is to adopt a laissez faire distribution of property rights, and rely entirely upon informal social forces rather than governmental action to control land use decisions. This policy has more to commend it than first appears; legal sanctions are among the least civilized ways of handling conflicts between neighbors. Socially harmful behavior generally has been most effectively controlled by socialization of the young, not the coercive force of law. If manners cannot deter certain antisocial behavior, like littering or poor maintenance of front yards, that behavior may not be efficiently controllable at all. ${ }^{16}$

The best-mannered societies tend to be small, long-lived, and stable in population. The historic beauty of Italian villages, or cities in the Netherlands and Switzerland, is undoubtedly attributable in large part to the smallness, antiquity, and stability of the societies that contain them. These characteristics foster more uniform acceptance of moral and aesthetic codes and allow stronger social sanctions against violations. The United States, a young, large country with a highly diverse and

15 Taverns and drive-in restaurants have been held to be public or private nuisances and consequently enjoined from further operation. See, e.g., State v. Rapauno, 153 So. 2d 353 (Fla. Ct. App. 1963); Annot., 5 A.L.R.3d 989 (1966); Annot., 91 A.L.R.2d 572 (1963). There are no reported American cases, however, holding that normally operated small groceries are nuisances. Cf. Annot., 146 A.L.R. 1407 (1943).

16 "Manners are of more importance than laws. Upon them, in a great measure, the laws depend. The law touches $u$ s but here and there, and now and then. Manners are what vex or soothe, corrupt or purify, exalt or debase, barbarize or refine us, by a constant, steady uniform insensible operation, like that of the air we breathe in." E. BurkE, Letters on a Regicide Peace, I (1797). 
mobile population is less able to produce good neighbors through social sanctions, and American cities suffer for it. ${ }^{17}$ In the Santa Monica Mountains case, it is unlikely that the good manners of Southern California entrepreneurs will optimally constrain the location and design of groceries; that degree of socialization may never occur in a society as mobile as that of Southern California.

If manners are not enough, it may suffice for government to aid the laissez faire system by providing enforcement mechanisms for contracts negotiated between a grocer and nearby homeowners bothered by his operation. ${ }^{18}$ This approach remains highly decentralized, since the grocer and his neighbors negotiate the price and terms of a transfer of control over land use from the grocer to the homeowners. A further modification occurs when government alters the laissez faire distribution of property rights by granting homeowners the right to reimbursement for certain types of harm caused by the land uses of grocers. When the parties then determine land use allocation through bargaining and litigation, the homeowners are able to force the grocer to bear more of the costs of his actions than he bears under the pure laissez faire system. In the Anglo-American legal system, this modified system is encompassed by the law of nuisance.

If greater intervention is necessary, the policy maker still has a range of options. Regulatory taxation is a mild form of public intervention. In the Santa Monica Mountains case, this system would involve a publicly assessed and collected tax on the grocery for its harmful qualities. A properly calculated tax would force the grocery to take into account the full social costs of its activities. ${ }^{19} \mathrm{~A}$ variation of regulatory taxation is a system of fines assessed without careful regard to the actual external costs of the penalized activity.

Regulatory taxation and fines are more centralized approaches than nuisance law and private agreements. The amounts of monetary transfers are established by unilateral public assessment rather than private negotiation, and enforcement is the responsibility of government offi-

17 The beautiful small towns of Vermont, with their historic color combinations of red barns and white houses with green trim, are evidence that manners can be an effective land use control under the right conditions even in the United States. These towns were not produced and maintained by legislative controls; they are the result of informal social pressures on anyone who would violate prevailing aesthetic norms. For a thoughtful analysis of the role of good manners and the conditions likely to foster them, see R. Mundell, Man and Economics 188 (1968).

18 These mechanisms would include rules on defenses, computation of damages, and the like, in addition to procedures and institutions for enforcement.

19 A concept of fairness may suggest that the injured homeowners should be the beneficiaries of the tax revenues. $C f$. text and note at note 301 infra. 
cials, not aggrieved private parties. These more centralized mechanisms retain some of the advantages of the market since the grocer, although forced to bear at least some of the external damage to his neighbors through the tax or fine, is free to choose whether or not to operate the grocery.

That free choice disappears as the internalization systems become more centralized. Mandatory minimum standards of conduct for permitted activities are the next device on the continuum. Such standards might be contained in ordinances that control the hours a grocery may be open, prohibit selected types of signs or roofing materials, or place a minimum on the amount of available parking space. Mandatory minimum standards prevent the grocer from undertaking a prohibited activity, even if he is willing to pay for its external costs. Standards are generally limited to undesirable subactivities incidental to a larger permitted activity, but the imposition of standards differs only in degree, not in kind, from mandatory prohibitions on activities. Prohibitions are more centralized than standards merely because the collective judgment being rendered is on a more momentous scale. ${ }^{20}$

The most centralized, nonmarket devices are collective directives to landowners, ordering them to carry out affirmative activities they would not otherwise undertake. An example of a directive is a mandatory order to a grocer to paint his store. A directive of this sort might issue under a housing code enforcement program or be contained in a court decree in a nuisance case. The line between standards and prohibitions on the one hand and directives on the other is not, however, a sharp one. As more activities and subactivities are prohibited through other devices, landowners are in effect directed into a specific course of action in developing their property.

A cataloguing of methods of internalizing harmful externalities gives but an outline of possible systems. All of the devices on the continuum of interventions, from informal sanctions to public directives, can be combined with infinite variety.

\section{Criteria for Evaluating land Use Control Systems}

How are intelligent choices to be made from this array of alternative actions? Problems of resource allocation have been attacked with the

20 Prohibitions and standards may be selective or blanket in scope. There are no grocery stores on the crest of the Santa Monica Mountains because the City of Los Angeles prohibits them in that location. This prohibition is selective, however, as the location of grocery stores elsewhere in Los Angeles is permitted. In mid-1971, the few commercially zoned tracts in the mountains within the city were either isolated from the largest residential areas or located far down from the crest in some of the larger canyons. For shopping, most residents must drive to stores at the foot of the mountains. 
greatest conceptual rigor by economists. They generally judge the impact of social policies by two basic standards: efficiency and equity. ${ }^{21}$ A measure is inefficient if it is likely to waste resources, that is, allocate scarce goods and services in a suboptimal manner. Equity, however, is a function of the distribution of resources, or who ends up with what share of the wealth. For example, uninternalized harmful spillovers from land use activities may not only result in inefficiencies, but may also cause redistributions of wealth that are perceived as unjust. Following other legal scholars who have applied welfare economics to problems of external cost, this article employs efficiency and equity as the two basic criteria for evaluating land use control systems. ${ }^{22}$

The notion of efficiency requires some dissection. When a conflict among neighboring land uses arises, three reasonably distinct types of resource diminutions may occur, singly or in combination. First, harmful externalities decrease the utility and thus the value of neighboring property. To keep the terminology as simple as possible, this factor will be called nuisance costs. Under a laissez faire distribution of property rights, these costs would probably be very high. A second possible source of resource diminutions will be termed prevention cosls. This category includes nonadministrative expenditures made, or opportunity costs incurred, by either a nuisance maker or his injured neighbor to reduce the level of nuisance costs. Prevention costs will tend to be higher when either or both of the parties are compelled to undertake specific steps than when they are permitted to select voluntarily among

21 The production and distribution of wealth, however, are not the sole societal concerns. Land use control policies, particularly highly centralized ones, can severely threaten individual liberty, a value not sufficiently recognized in economic theory. This analysis devotes little space to liberty issues, not because of unimportance, but because the deprivations of liberty caused by land use regulations, or uninternalized nuisances, are rarely perceived as severe. See also text at notes 208-11 and 231-38 infra. For observations on liberty issues that arise from efforts to control land development, see Dunham, supra note 6, at 38-43; Michelman, Property, Utility, and Fairness: Comments on the Ethical Formulation of "Just Compensation" Law, 80 H.ARV. L. REv. 1165, 1201-02 n.77 (1967) [hereinafter cited as Michelman, Property]. See also Calabresi \& Melamed, supra note 11, at 1093, 1101-05.

22 In his examination of accident law, Calabresi states his goals as the "reduction of accident costs" within the constraint of "justice." G. Calabresi, Cost of Accidents, supra note 11, at 24-33. Except for the ambiguities in his scheme discussed in note 29 infra, these goals seem functionally comparable to efficiency and equity. Michelman's heroic investigation of the issue of when government must compensate for losses occasioned by public action revolves primarily around the goals of "utility" and "fairness." Michelman, Property, supra note 21. Those goals correspond to the same economic notions. See id. at 1181-83. The terms efficiency and equity are used here because they have greater currency outside legal literature. For more on the Calabresi and Michelman classification systems, see notes 25 and 29 infra. 
available preventive measures..$^{23}$ Finally, administrative costs may also diminish resources. This term will be used to encompass both public and private costs of getting information, negotiating, writing agreements and laws, policing agreements and rules, and arranging for the execution of preventive measures.

If administrative costs are zero, optimal resource allocation is achieved when the sum of nuisance costs and prevention costs is minimized. ${ }^{24}$ It will rarely be efficient to eliminate all nuisance costs, since that action will ordinarily require unacceptable levels of prevention costs. A major city could easily extinguish all nuisance costs from gas stations by banning them within city limits. Such a measure, however, would involve high prevention costs as all motorists would have to take long, annoying trips to the suburbs to service their cars. Prevention costs in this instance would probably far exceed the eliminated nuisance costs, and overall efficiency would not be enhanced..$^{25}$

23 When a preventive step has utility to its sponsor other than its reduction of nuisance costs, the value of that utility is not a part of the prevention cost. For example, if a homeowner buys an air conditioner to combat air pollution, the prevention cost is the sales price of the air conditioner less the price the purchaser would have agreed to pay for the appliance if there were no air pollution.

Given the possibility of minimizing prevention costs by maximizing the independent utility of preventive action, the parties will seek the device or action that, in their particular situation, provides the maximum independent utility. Permitting the parties to select voluntarily among available preventive measures is clearly more conducive to optimal resource allocation than the imposition of a uniform preventive measure in all situations.

24 Coase, Social Cost, supra note 2, at 3-8; cf. G. CALABresi, Cost of Accidents, supra note 11, at 26-31. For a fuller treatment of the Coase analysis, see text at notes 159-63 infra.

25 Some components of nuisance costs and prevention costs may be quite subtle. Assume that a major manufacturing facility is closed down, either because an incompatible neighboring use makes its continued operation unprofitable, or because it has been abated as a nuisance or a nonconforming use under a zoning law. The shutdown may cause widespread unemployment in the short run and have other disruptive effects on the economy. The land use policy that caused the demise of such a conspicuous employer may demoralize firms and workers, causing reduced output, and generally discourage entrepreneurs and investors because of the uncertainties created. Calabresi and Michelman have both enriched, and complicated, their analyses by separately classifying such costs. As they certainly recognize, however, these costs are different only in subtlety, not in kind, from the other classifications of costs they use. Thus, Michelman could have simplified his approach by regarding "demoralization costs" as a subcategory, to be considered negatively in computing a measure's "efficiency gains." Michelman, Property, supra note 21, at 1214-15. The subtle efficiency losses Calabresi denominates "secondary costs," see note 29 infra, are perhaps less immediate than what he calls the "primary costs" of accidents, but they could easily have been included under that heading. The Michelman and Calabresi classifications of costs may be appropriate to the "taking" and "accident" contexts for which they were developed, but they seem unnecessarily complex for application to land use problems. "Nuisance costs" and "prevention costs," as used here, include all subtle, indirect, long-term losses from either harmful externalities or prevention systems. 
The weighing of nuisance costs and prevention costs is further complicated by the fact that in reality administrative costs are not zero. All land use control systems involve some form of administrative costs. These costs may be collectivized through government, as in the case of salaries for zoning officials, or borne directly by private persons, as in the case of the costs of inculcating good manners, arranging for the installation of preventive devices, litigating nuisance suits, or deciphering zoning codes. The overall goal from an efficiency standpoint is the minimization of the sum of nuisance costs, prevention costs, and administrative costs.

The goal of equity, however, complicates matters considerably; an efficient policy may be an unfair one, particularly when the gains of the policy are not distributed to those injured by its imposition. ${ }^{26}$ Because they have found no theoretically sound basis for making interpersonal comparisons of utility, many economists believe that they can at best only describe the wealth transfer effects of a policy, but that they cannot assess the fairness of those transfers. Thus, they either ignore the issue of equity ${ }^{27}$ or defer to courts and legislatures.. ${ }^{28}$ The legal profession can certainly provide guidance to those institutions, and most legal scholars writing on welfare economics have been careful to consider equity criteria in their analysis. ${ }^{29}$ The degree of unfairness

26 If a policy is efficient, its total gains by definition exceed the harm it imposes.

27 Coase deliberately avoids consideration of equitable issues in his landmark article: "The economic problem in all cases of harmful effects is how to maximize the value of production." Coase, Social Cost, supra note 2, at 15; "When an economist is comparing alternative social arrangements, the proper procedure is to compare the total social product yielded by these different arrangements." Id. at 34 .

28 See, e.g., Dolbear, On the Theory of Optimum Externality, 57 AMER. Econ. Rev. 90-9l n.3 (1967). An impressive exception is Thurow, Toward a Definition of Economic Justice, Pub. InTEREst, Spring, 1973, at 56.

29 See note 22 supra. Calabresi treats undesirable changes in income distribution not primarily as issues of "justice," but as "secondary costs," which his formulas require to be added to what are here termed administrative costs, prevention costs, and accident costs. G. Calabresi, Cost of Accidents, supra note 11, at 24 n.1, 27 n.4, 28 n.6. He is aware that economists would be troubled by this classification, since they assert no such summation is possible. Although Calabresi at times suggests the contrary, see id. at 24 n.1, presumably the "justice" constraint would also take into account harsh fluctuations in wealth brought about by an accident law system. His "secondary costs" also apparently include subtle efficiency losses; at least Michelman thinks that was Calabresi's intention. See Michelman, Book Review, supra note 11, at 650, 682. Michelman himself is perhaps not consistent in his interpretation of "secondary costs." Compare id. at 650 n.10, with id. at 682. From a standpoint of sound economic theory and to avoid the resulting confusion, Calabresi perhaps should have considered all distributional issues under the "justice" goal, not the "accident cost reduction" goal. Cf. Posner, Book Review, 37 U. CHI. L. REv. 636, 644 n.17 (1970). 
of a system obviously cannot be quantified and persuasive arguments about fairness issues are hard to construct; nevertheless legal scholars must confront an issue so central to the law. ${ }^{30}$

\section{An Evaluation of Zoning}

The analytical framework constructed above will first be applied to zoning. ${ }^{31}$ Zoning relies primarily on selective prohibitions and the imposition of mandatory standards on permitted activities, and thus lies toward the collective end of the spectrum of alternatives. Generalizing about a local governmental practice like zoning, however, is dangerous business. There is no consistent practice as to what will be included in a zoning ordinance; further, many local governmental prohibitions, mandatory standards, and directives affecting land use may be contained in regulations falling under other labels-subdivision regulations, building codes, housing codes, fire codes, health codes, and the like. From an economic standpoint, however, local zoning regulations are the most significant land use controls; in most areas they have a far greater effect on land values than other kinds of regulatory ordinances. Thus zoning constitutes an ideal model for highlighting the economic consequences of all types of mandatory regulations.

The regulatory framework of zoning ordinances in the United States is surprisingly uniform. The typical structure is based on the landmark New York City zoning law of $1916^{32}$ and the Standard State Zoning

30 Professor Michelman has proposed as a standard of fairness that requiring a person to bear a loss is not unfair if he should be able to perecive that refusing compensation to people in his situation is likely to promote the welfare of people like him in the long run. Michelman, Property, supra note 21, at 1223. This article invokes Michelman's standard of fairness, despite its operational difficulties, more often than any other one. His fairness test is obviously linked to efficiency considerations. See text and note at note 69 infra. Michelman's standard for fairness is analogous in many respects to John Rawls's second basic principle of a just society: "social and economic inequalities, for example, inequalities of wealth and authority, are just only if they result in compensating benefits for everyone, and in particular for the least advantaged members of society." J. RAwLS, A TheORY OF Justice 14-15 (1971). Both the Michelman and Rawls approaches show a kinship in many respects to the classical economic notion of Pareto optimality.

31 Zoning literature has mushroomed in the last decade. Some of the better general sources on the subject include: Model LANd Development Code (Tent. Draft No. 2, 1970); J. Delaflons, Land-Use Controls in the United States (1962); D. Mandelker, The Zoning Dilemma (1971); Building the American City, supra note 4, at 199-253; L. SAgAlyn \& G. STERnlieb, Zoning ANd Housing Costs (1973). For an economic analysis of zoning, see sources cited note 2 supra and Alonso, Location AND LAND USE 117-25 (1964).

32 The evolution of this ordinance is detailed in two recent historical treatments of zoning. S. Makielski, The Politics of Zoning: The New York Experience (1966); S. Toll, Zoned American (1969). See also Note, Development Rights Transfer in New York City, 82 YALE L.J. 338, 339-44 (1972). 
Enabling Act issued by Secretary of Commerce Herbert Hoover in 1922. ${ }^{33}$ Although a few major cities had earlier made modest attempts to control land uses, the precedent of the New York City ordinance triggered the rapid spread of zoning, apparently because of its political appeal as a device to protect the value of single-family homes. By 1925 , 368 municipalities had zoning ordinances; in 1926 the United States Supreme Court upheld zoning against constitutional challenge, ${ }^{34}$ and by 1930 the number exceeded $1,000 .^{35}$ By 1967 , over 9,000 governments exercised zoning powers, nearly 50 percent of the municipalities first adopting their ordinances after $1950 .{ }^{36}$ Today, zoning is virtually universal in the metropolitan areas of the United States, where more than 97 percent of cities having a population over 5,000 employ it. ${ }^{37}$ Of cities with over 250,000 population only Houston, Texas, has not enacted a zoning ordinance..$^{38}$

Zoning typically involves at least two types of controls. First, the authorities define classes of activities, termed uses, that are permitted in each geographic area. The specificity of use zones is increasing; while the original New York ordinance had only three types of use districts, ${ }^{39}$ the current ordinance contains sixty-six. ${ }^{40}$ In addition, the zoning officials set structural restrictions. The early controls of this type were primarily concerned with building and lot dimensions, but recent ordinances impose broader regulations dealing with matters like minimum parking space and the use of signs. Both types of restrictions are mandatory in application; violators receive orders of compliance, not fines or regulatory taxes. Further, zoning is primarily prospective in nature due to the harshness of retroactive application. Nonconforming uses and, to a greater degree, nonconforming structures that preexist zoning restrictions are generally allowed to continue.

Zoning regulations are enforced in large part through review by local building officials of plans for proposed developments. Permits for new construction, or the rehabilitation of existing structures, are granted only if the proposals conform to zoning restrictions. Most municipalities have a board of zoning appeals to review the decisions

33 Reprinted in Model Land Development Code 210-21 (Tent. Draft No. 1, 1968).

34 Village of Euclid v. Ambler Realty Co., 272 U.S. 365 (1926).

35 Building the American City, supra note 4, at 200.

36 A. Manvel, Local Land and Building Regulations 23, 31 (National Commission on Urban Problems Research Report No. 6, 1968).

37 Id. at 24.

38 Id. at 17.

39 The city was divided only into "residence," "business," and "unrestricted" zones. Lincoln Trust Co. v. Williams Bldg. Corp., 229 N.Y. 313, 316, 128 N.E. 209, 210 (1920). 40 Mandel, Zoning Laws: The Case for Repeal, 135 Archrtectural Forum 58 (1971). 
of local officials on permit applications and to grant variances from the ordinances to relieve "unnecessary hardship." The modern trend, however, is to have prohibitions on use relieved not by the zoning appeals board but by "special exception" or a map amendment approved by the local legislature. Actions of both the board of zoning appeals and the local governing body are subject to judicial review to assure compliance with applicable procedural and substantive law.

\section{A. Zoning and Efficiency}

Despite the difficulty of discussing the uncoordinated practices of over 9,000 local governments, the basic structure of zoning and present knowledge about its effectiveness will support some general observations about its likely efficiency as a land use control system.

1. Reduction in Nuisance Costs. Since zoning inevitably results in considerable prevention and administrative costs, large reductions in nuisance costs would have to be forthcoming for zoning to be deemed efficient. At present, zoning administrators either ban or greatly restrict the location of highly undesirable uses. Where a noxious use is permitted, planning officials generally try to place it adjacent to activities not particularly vulnerable to the type of harm caused by that use. For example, most zoning ordinances cluster industrial uses,. often placing the cluster adjacent to railroad tracks. Similarly, apartment zones are commonly placed next to highways, perhaps on the assumption that if apartment dwellers must tolerate the noise coming through the party walls of their building, they should not be especially sensitive to the hum of nearby automobiles. Most ordinances also set aside large areas exclusively for single-family homes, a land use perceived as particularly vulnerable to external harm.

These locational decisions unquestionably reduce the nuisance costs that would occur if land uses were randomly distributed. Nonzoning allocations, however, may also be better than random. Urban land markets automatically reduce nuisance costs far below the level that would be found with random land use distribution. Industrial plants are not attracted to prime residential areas; instead they naturally congregate along railroad tracks, just where zoning is likely to put them. By such clustering, they are likely to achieve the benefits of convenient access to major shipping lines and supporting service industries, less vandalism, and lower risk of injury to neighborhood children. Similarly, Bernard Siegan found that automobile dealerships in Houston tended to locate benignly. ${ }^{41}$ All twenty-four of the "Big Three" dealerships he

41 Siegan, Non-Zoning, supra note 2, at 104-05. 
examined were located on major thoroughfares, and in twenty-one cases he could find no loss in the value of neighboring properties. It is difficult to disagree with Siegan's conclusion that a nonzoning system seems to have allocated these uses as efficiently as any zoning scheme could have. Thus, even if a zoning system is more efficient than random land use, it does not necessarily follow that it reduces nuisance costs more than the market mechanism.

In addition, zoning does not guarantee either elimination or internalization of nuisance costs. Assume that a small parcel on the crest road of the Santa Monica Mountains is rezoned for commercial uses, and subsequently a convenience grocery store is built. If the zoning change is legally sound, the neighboring homeowners who suffer losses in property values are without a remedy, and the store is allowed to operate without bearing its full social costs. The frequency with which zoning changes occur ${ }^{42}$ prompts fear that such failures are not uncommon. Between 1964 and 1967, 30 percent of cities in the United States with populations over 50,000 either enacted or comprehensively revised their zoning ordinances. ${ }^{43}$ Nationally, about three-quarters of all rezoning applications are approved by governing bodies, and a slightly greater fraction of variance requests are approved by the boards of zoning appeals. ${ }^{44} \mathrm{~A}$ landowner where zoning is in flux could potentially receive more certain protection from both covenants and nuisance law than he receives from zoning. ${ }^{45}$

2. Prevention Costs. The great danger, however, is not that the drafters of zoning ordinances will fail to eliminate nuisance costs, but that they will try to eliminate them all. The pertinent goal is minimization of the sum of nuisance, prevention, and administrative costs. If zoning is directed solely toward eliminating nuisance costs, planners will impose land use controls so restrictive as to create inefficiently high prevention costs. For example, the zoning authorities in Los Angeles have focused on the slight damage that might be inflicted on a few homeowners if a small grocery store were built in the Santa Monica

42 Amendments tend to be less easy to secure, however, in expensive residential areas like the Santa Monica Mountains.

43 A. MANVEL, supra note 36 , at 31 .

44 Id. at 32-33. Manvel's national data corroborate the findings of local surveys on the variance process. See, e.g., C. HaAR, LANd-Use Planning 296-97 (1959). The percentage of applications granted may overstate the ease of obtaining a desired modification, since hopeless requests for changes may never be brought or be discouraged before the formal application stage.

45 The effectiveness of covenants and nuisance law in protecting property values, of course, depends on the substantive rules governing those systems. See text and notes at notes 118-268 infra. 
Mountains and banned such land uses. ${ }^{46}$ As a result, many mountain residents incur the prevention cost of a twenty-minute round trip to buy groceries, a total burden to them far more costly than the nuisance cost of a neighboring grocery to a few homeowners. Elsewhere in Los Angeles about one-half the land surrounding the UCLA campus is presently zoned for single-family housing. Since over 50,000 people work or study at UCLA every day, the demand for apartment accommodations in this area is tremendous. By seeking to protect a few hundred homeowners from the harms caused by apartments, ${ }^{47}$ the Los Angeles planners have imposed substantially higher commuting costs on a large segment of the population, and aggravated their city's traffic, noise, and air pollution problems. Another example is found in the common prohibition against the use of single-family homes as business offices; this policy prevents professionals and small businessmen from economizing on rental expenditures and travel costs, and deprives residential areas of conveniently located professional and business services. ${ }^{48}$ Even where a prohibition is desirable, the abatement of a preexisting nonconforming use often inflicts losses that appear large in comparison to the reduction in nuisance costs achieved. ${ }^{49}$

Structural restrictions may also be a major source of prevention costs. For example, fixing minimum lot sizes larger than consumers demand increases the amount of urban land that must be consumed in order to accommodate a given population increase; thus metropolitan areas tend to spread farther than they would under a free market, ${ }^{50}$ increasing transportation and utility costs throughout the urban network. Imposition of maximum building sizes may also involve prevention costs. In Manhattan, architects designing highrise apartments have frequently been instructed by developers to make maximum use of the zoning envelope allowed. Prior to the early 1960 's, this policy produced structures in the form of wedding cakes and more recently sheer towers with tiny, useless plazas in front of them. ${ }^{51}$ Without doubt, building

\footnotetext{
46 See note 20 supra.

47 These homeowners might be better off from a financial standpoint if the area were rezoned for apartments. Such a change would greatly increase the value of their land and, after selling out, they could move into a nicer home in nearly as convenient a neighborhood.

48 See, e.g., Skrysak v. Village of Mount Prospect, 13 Ill. 2d 329, 148 N.E.2d 721 (1958) (upholding a prohibition against opening a dental office in a single-family home).

49 This can occur even where constitutionally mandated amortization periods are applied. See, e.g., Los Angeles v. Gage, 127 Cal. App. 2d 442, 274 P.2d 34 (1954) (affirming termination of wholesale and retail plumbing supply business within five years).

50 In cases where the demand for land is highly elastic, however, lot size minima could actually reduce the consumption of urban land.

51 See Mandel, supra note 40 , at 59.
} 
bulk controls caused major inefficiencies in the interior layouts of these buildings and adversely affected architectural variety in the city, in return for at best insignificant improvements in the protection of the city's light and air. ${ }^{52}$ Side yard requirements in residential areas are perhaps a more common example of controls with high prevention costs. If the width of each side yard must be 10 percent of the width of the lot,,$^{53}$ the inventory of buildable urban land is thereby reduced by one-fifth. This is a high price for the elimination of all risk that a building will block a neighbor's light and air. If neighbors negotiated the uses of the respective sides of their parcels, it is unlikely that many would make agreements that so depleted their supply of buildable land.

Other prevention costs resulting from zoning are more subtle. In most communities, for example, zoning ordinances are designed to promote the interests of single-family homeowners, often a majority of the voting population. This constituency generally prefers strict zoning controls, a policy that eventually causes a buildup of market demand for some development not permitted by existing zoning regulations. When this demand becomes large enough, the prodevelopment forces are usually able to finance a winning campaign for a relaxation of control, and an outbreak of new land development follows. This pattern of long pauses in development, followed by bursts of activity, can create substantial inefficiency in the land development industry. For example, a prospective tightening of zoning restrictions on highrise apartment buildings in New York City caused construction of an artificially high number of apartments in the early 1960's. This overbuilding was a major cause of the 75 percent drop in private apartment construction in Manhattan from the first half of the 1960's to the second. ${ }^{54}$ The economic effects of this artificial boom-and-bust cycle were probably great enough to impede the efficient functioning of local construction firms and cause suboptimal employment of labor in the building trades. Similarly, the pendulum cycle of zoning may require architects and civil engineers to incur the expense of revising

52 Some architecture critics have asserted that the proliferation of plazas in New York City since the 1961 zoning amendments has created, notably on Sixth Avenue, an undesirable "broken teeth effect" of random open space. See Space Rates, NEw York, Feb. 19,1973 , at 9 .

53 A common requirement in the City of Los Angeles ordinance.

54 During 1961, the last year the old ordinance was in effect, developers filed plans for 150,000 multiple dwelling units in all of New York City. Under the new ordinance, applications for permits fell to 6,700 units in 1962 and 42,000 in 1963. Completion of units lags behind the granting of permits by several years. See Kristof, Housing: Economic Facets of New York City's Problems, in Agenda for A City: Issues Confronting New York 328 (L. Fitch \& A. Walsh eds. 1970). 
plans already on their drawing boards in order to accommodate the latest shift in political winds.

Delay is another subtle but major prevention cost inflicted by legislated land use regulations. ${ }^{55}$ Particularly when elections are approaching, uncertainties about the timing and substance of public decisions force developers to gamble on when to mobilize men and equipment. Conservative developers thus extend lead times in construction schedules, sometimes by years, to minimize the risks of having their resources idled by political developments.

3. Administrative Costs. The most conspicuous administrative cost of zoning is the direct cost of operating a public planning agency. Local governments, however, are tightfisted in budgeting for their planning staffs, and direct public costs are actually quite low. The Manvel survey found that, in 1967, total spending by municipalities for planning, zoning, and subdivision regulation was $\$ 70$ million, only $61 \phi$ per capita for the cities involved. ${ }^{56}$ That amount is less than half of the spending on building code administration. ${ }^{57}$

Planning and zoning operations also impose more indirect expenses on local governments. For example, Manvel did not include the stipends paid, or the good will exhausted, through the use of voluntary labor to staff zoning appeals boards and planning commissions. Since land use regulation is one of the major activities of local government, a significant fraction of general governmental costs should be attributed to it. ${ }^{58}$ Conflicts over land use regulation that are judicially resolved may impose another sort of public cost. Local governments seek to shift many of these public costs to private parties by imposing fees for efforts to change existing regulations, or for securing permits to proceed under them.

The private administrative costs necessitated by zoning systems far exceed the public costs. Developers of urban land, and traders of urban property, must investigate any public land use restrictions governing development. The existence of zoning means that builders, land speculators, civil engineers, architects, financial institutions, lawyers, and

55 There have been relatively few attempts to quantify the costs of delay. One multiple regression analysis of variables affecting the sales prices of new single-family houses in New Jersey indicates that each month of administrative delay in subdivision approval adds an additional ninety-one dollars to the selling price in urbanized subdivisions. $L$. Sagalyn \& G. Sternlieb, supra note 31 , at 62 . See also id. at 59.

56 A. MANvel, supra note 36 , at 29.

57 Some of the code administrative cost should be included as a zoning cost, however, since building officials help enforce zoning ordinances through the permit system.

58 E.g., salaries of local officials, fees paid legal counsel, and overhead items like clerical services and building maintenance. 
others involved in land development must maintain libraries of local land use regulations and spend time studying them. These information costs are greatly increased by the rapid changes in the regulations. ${ }^{59}$

Substantial costs are also incurred when a landowner attempts to amend the regulations related to his property through one of the many avenues provided by the zoning system. In the case of major zoning changes, large developers often wine and dine local officials, hire expensive consultants to make presentations at public hearings, initiate large public relations campaigns, ${ }^{60}$ and make judicious campaign contributions to key local officials. Another form of private cost is incurred if neighboring homeowners organize to lobby in opposition to the developer. In major metropolitan areas zoning generates enough legal conflicts to support several law firms specializing in zoning law. By crude measurement zoning now produces almost four times as many appellate opinions as nuisance and covenant law disputes combined. ${ }^{61}$ In many cities the total legal fees paid to zoning attorneys probably significantly greater than the direct costs of running the public zoning agency.

There are yet more subtle administrative costs that deserve mention. The structure of local government in the United States is largely shaped by the primary power that these governments have over land use regulation. Many municipal boundary changes may in reality be enacted mainly to manipulate regulations governing land use. For example, landowners in Maryland suburbs of Washington, D.C., have frequently attempted to annex their properties to incorporated cities, like Bowie or Gaithersburg, to avoid the stricter county zoning .ordinances. The nationally publicized incorporation of Black Jack, Missouri, was inspired solely by a desire to exercise zoning power. ${ }^{62}$ Many cities in Southern California contract with their counties for virtually all local services, retaining land use regulations as their sole active con-

59 See text at notes $42-44$ supra.

60 In a zoning battle over its proposed new corporate headquarters in Greenwich, Connecticut, the Xerox Corporation commissioned a $\$ 250,000$ study by an eminent planning firm and delivered copies of the study to most of the town's residents. NEWSWEEK, June 5,1972 , at 80,82 .

61 This estimate is based on the number of pages of case headnotes found under the "Nuisance," "Covenants," and "Zoning" headings in Volumes 12-15 of West's GeneraL Digest (4th Series), covering all appellate cases reported by the West system in the year 1970. Those four volumes include seventy-six pages on zoning, but only ten pages each on nuisance and covenants. The reliability of this system of measurement is diminished to the extent that the number and length of the headnotes generated by typical cases in each category are substantially different.

62 For background on the Black Jack controversy, see National Observer, Feb. 8, 1971 , at $1,14$. 
cern. ${ }^{63}$ One doubts whether these cities would even exist but for the opportunity to exercise zoning power.

The total public and private administrative costs of zoning are far from insubstantial. These costs, when added to the high prevention costs zoning is likely to involve, may be so great that an entire zoning ordinance is inefficient; that is, the reduction in nuisance costs is less than the concomitant prevention and administrative costs. This occurrence is probably extremely common in the United States. Thus, other internalization devices are likely to be better equipped to deal with many problems now handled by zoning. Nevertheless, the efficiency of zoning as an internalization device varies with the specific type of externality at issue. This article will suggest later ${ }^{64}$ that mandatory regulations may indeed be the most efficient device for dealing with a few pervasive land use problems.

\section{B. Zoning and Equity}

Zoning can promote equity by prohibiting unneighborly acts, thereby protecting some landowners from privately inflicted losses. As it is usually operated, however, zoning is an inequitable system; the Achilles' heel of zoning is that it does not correct the changes in wealth distribution it causes. When a zoning decision increases the value of a parcel, the owner is generally not obligated to disgorge the increased value. Conversely, when a zoning action reduces property values, an owner is not compensated for any losses unless he can obtain a judicial decision that the ordinance constitutes an unconstitutional "taking." 65

The effect of these policies is significant since zoning often affects land values by multiples, not fractions. If a well-located parcel in the Santa Monica Mountains were rezoned to permit grocery stores, the value of the property would probably increase several times. In some cases suburban land values have been multiplied by fifty following rezoning that allowed construction of gas stations. ${ }^{66}$ Risks of loss can be equally dramatic, as illustrated by the famous case of Village of Euclid v. Ambler Realty Co. ${ }^{67}$ In Euclid, zoning restrictions reduced

63 Bradbury, Hidden Hills, and Rolling Hills in Los Angeles County are examples.

64 See text at notes 313-18 infra.

65 The fifth amendment cautions the federal government: "nor shall property be taken without just compensation." The due process clause of the fourteenth amendment has been interpreted similarly to constrain the states. See, e.g., Chicago, B. \& Q. R.R. v. Chicago, 166 U.S. 226 (1897). Most state constitutions have comparable provisions; many also prohibit the "damaging" of private property without compensation. Nichols, EMINENT Domain § 6.1 [3] (3d ed. 1970).

66 Building the American City, supra note 4, at 226, citing a study by Grace Milgrim in Philadelphia.

67272 U.S. 365 (1926). 
the value of part of the plaintiff's property by 75 percent. The plaintiff introduced evidence, accepted as uncontroverted by the United States Supreme Court, demonstrating that the zoning enactment had reduced its property values by over $\$ 300,000$, or more than one-third. ${ }^{68}$ The Supreme Court held that the village's zoning ordinance was constitutional, and the realty company was not compensated for any part of the loss. Of course, the loss may achieve higher proportions. Suburban building companies commonly fear that land bought for subdivisions will be rezoned into agricultural estates, a use restriction that could wipe out most of their investment.

How can one judge whether changes in individual levels of wealth caused by zoning are fair? The legal issue is usually stated to be whether a "taking" of property has occurred for which just compensation must be paid. Michelman asserts in his "fairness" test that it is not unfair for an individual to bear a loss caused by a government regulation if he should be able to see that, in the long run, failure to compensate people in his position will be in the best interest of people in his situation. ${ }^{69}$ Under this test the paradigm case for noncompensability is where: (1) the efficiency of the government program that caused the

68 The plaintiff's tract in Euclid consisted of 68 acres with an 1,800-foot front on Euclid Avenue, its southern boundary. 297 F. 307, 309 (N.D. Ohio 1924). In deciding the case, the Supreme Court accepted the Realty Company's allegation that the strip abutting Euclid Avenue, roughly eight acres about 1,800 feet long and 200 feet wide, had been diminished in value from $\$ 150$ per front foot to $\$ 50$ per front foot. 272 U.S. at 384 . The next area back from Euclid Avenue, about twenty acres extending as much as 1,800 feet in length and 550 feet in depth, was alleged to have diminished in value by the restriction to residential use from $\$ 10,000$ an acre to $\$ 2,500$ an acre. $I d$. The northern part of the parcel, constituting the remaining forty acres, was zoned for industrial purposes, the highest and best use. The height and bulk restrictions on that area will be ignored and its value considered undiminished. The total loss suffered by the Realty Company can then be charted as follows:

\begin{tabular}{lcrr}
\hline & $\begin{array}{c}\text { Prezoning } \\
\text { Value }\end{array}$ & $\begin{array}{c}\text { Postzoning } \\
\text { Value }\end{array}$ & Diminution \\
\hline $\begin{array}{l}\text { Euclid Ave. } \\
\text { Frontage }\end{array}$ & $\$ 270,000$ & $\$ 90,000$ & $\$ 180,000$ \\
Next 550 feet & 200,000 & 50,000 & 150,000 \\
Remaining & 400,000 & 400,000 & $-0-$ \\
acreage & $\$ 870,000$ & $\$ 540,000$ & $\$ 330,000$ \\
\hline
\end{tabular}

69 See text and note at note 30 supra. This standard is not a "pure" fairness test since it turns on the claimant's calculation of the efficiency of compensation policies and his likelihood of sharing in the gains of an efficient policy. Since all distributional policies, other than random policies, affect the efficiency of resource allocation, determinations of fairness are inevitably influenced by efficiency considerations. 
loss is transparently obvious, (2) the administrative costs of compensation are high, and (3) the losses suffered are small and widespread. In such a situation, the injured individual will want the public program to continue and can see that his interests as a taxpayer may be best served in the long run if the government does not spend large sums in arranging to make trivial payments.

Losses from zoning have only one characteristic in common with the paradigm case; the administrative costs of making compensatory payments would be high indeed. The earlier efficiency analysis indicated, however, that zoning normally will not be so obviously efficient that the injured party would be disturbed by compensation rules that made continuation of the zoning program difficult. More significantly, the sorts of losses inflicted by zoning are often too great in magnitude, too haphazard in incidence, and too infrequent over an individual's life span to lead him to believe that in the long run the losses from the program, even if random, would be fairly spread among landowners.

The situation is aggravated, from a fairness standpoint, by the aggrieved landowner's knowledge that zoning decisions are not random. Zoning is not a perfectly balanced roulette wheel, randomly bestowing its wins and losses. In most communities the wheel is warped; friends of the house come out winners while others are losers. Given the huge amounts at stake, it is not surprising that special influence problems have plagued zoning from its inception. The Fifth Avenue Association, a strong force behind the passage of New York City's 1916 zoning law, shaped that ordinance to serve its narrow interests, ${ }^{70}$ and "practically drafted its own use district" 71 when the New York ordinance was revamped in 1960. Special influence can be used by businessmen to remove restrictions on their own land, and also to maintain or tighten restrictions on competitors' property in order to bar competing enterprises. ${ }^{72}$ Reliable statistics on graft in the zoning process are lacking, but a national commission that recently investigated zoning found that "outright corruption is far from rare" and pointed to the "increasingly frequent newspaper exposes of corruption."'73

70 S. Toll, supra note 32 , at $173-80$.

71 S. MAKIELSKI, supra note 32, at 102.

72 See, e.g., Forte v. Borough of Tenafly, 106 N.J. Super. 346, 255 A.2d 804 (1969), where a would-be supermarket developer, who suffered a rezoning that barred his project, alleged that the rezoning was for the "sole benefit of the merchants in the central business core." $I d$. at 351,255 A.2d at 806.

73 Building the American City, supra note 4, at 226. As evidence of this phenomenon, consider the following casual compilation of recent newspaper stories. In New York City, a builder was indicted for perjury for denying attempting to bribe a city planning commissioner to vote against the granting of a special permit to a competitor. N.Y. Times, 
The pervasiveness of special influence is inherent in the zoning system. Judicial insistence on uniform standards for decision, a basic way of preventing favoritism in government, is not possible in the case of zoning; the name itself suggests a system of nonuniform regulation. Since the courts cannot easily distinguish good planning from bad, judicial checks on unfair variations in land use restrictions have been minimal. Studies have documented the lawlessness of zoning variance decisions in most communities. ${ }^{74}$ Many courts have stopped trying to police local zoning and consistently sustain the local government's action under the "presumption of validity" given to zoning provisions. ${ }^{75}$

Local governing bodies have also manipulated zoning to benefit their treasuries at the expense of arbitrarily designated landowners. One practice, rarely withstanding judicial scrutiny when detected, is to zone restrictively a parcel destined to be condemned for a public project, thus reducing its fair market value and the amount of compensation the government will owe the landowner. ${ }^{76}$ A more common, and legal, technique is to restrict most of the undeveloped land within the municipality, and then require developers to buy development rights through some form of public contribution. The most common currency for repurchase of development rights is dedication of part of the developer's land for school sites, parks, roads, or utilities. Increased levels of exac-

Jan. 1, 1970, at 14. A former commissioner of Prince George's County, Maryland (a suburb of Washington, D.C.), was convicted of taking a bribe from a land developer in return for favorable consideration of rezoning applications. Washington Post, Oct. 28, 1971, at A-1, A-14. Two Chicago aldermen were indicted for extorting bribes for zoning changes. Washington Post, Mar. 29, 1973, at A-4. A surge of zoning bribery convictions has recently swept southern California. These involved several officials of the City of Carson, L.A. Times, Jan. 8, 1972, at Part II, 3; a Los Angeles City Councilman, L.A. Times, Sept. 9, 1972, at Part II, 1; and an influence peddler in Santa Barbara County, L.A. Times, Mar. 24, 1973, at Part I, 1. For more California dirt, see R. Fellmeth, supra note 5, at 482-86. The abuses discovered by investigators are assuredly only the tip of the iceberg.

74 C. HAAR, supra note 44, at 296-97; Babcock, The Unhappy State of Zoning Administration in Illinois, 27 U. CHI. L. REv. 509 (1959); Dukeminier \& Stapleton, The Zoning Board of Adjustment: A Case Study in Misrule, 50 KENT L.J. 273 (1962); Shapiro, The Zoning Variance Power-Constructive in Theory, Destructive in Practice, 29 MD. L. REv. 2 (1969); Yokley, The Place of the Planning Commission and Board of Zoning Appeals in Community Life, 8 VAND. L. REv. 794 (1955); Comment, Zoning: Variance Administration in Alameda County, 50 CALIF. L. Rev. 101 (1962); Note, Zoning Variances and Exceptions: The Philadelphia Experience, 103 U. PA. L. REv. 516 (1955).

75 Although local governments win a vast majority of the cases, some courts are willing to invoke the prohibition against "spot zoning" and similar doctrines to overturn rezonings that appear suspiciously arbitrary. Some courts have also struck down flexibility de vices in zoning that fail to contain standards adequately limiting the discretion of the governing body. See, e.g., Eves v. Zoning Bd. of Adjustment, 401 Pa. 211, 164 A.2d 7 (1960).

76 See, e.g., Kissinger v. Los Angeles, 161 Cal. App. 2d 454, 327 P.2d 10 (1958); Annot., 36 A.L.R.3d 751 (1971). 
tions ultimately work a redistribution of wealth to existing residents from owners of undeveloped land in the jurisdiction when the exaction policy is announced. In most situations a local government cannot justly single out that group as a target for taxation while exempting owners of developed land from the tax. Under Michelman's standard ${ }^{77}$ this practice would be inequitable since the administrative burden of compensating the developer would be slight.

Zoning as a system of local government finance has recently taken an imaginative leap in that pioneer of land use regulation, New York City. The city has begun to lease the free space over city-owned structures to owners of adjacent lots who use that space to increase the zoning envelope applicable to their lots. ${ }^{78}$ In short, the city is selling development rights it had earlier zoned away. If administered uniformly, the sale of extraordinary development rights could approximate a system of fines, an attractively flexible system of land use regulation. ${ }^{79}$ In New York, however, it has appeared to be a series of ad hoc deals, ${ }^{80}$ a pattern certain to involve serious inequities and corruption. ${ }^{81}$ "Bonus zoning," a recently developed technique now in effect in San Francisco, New York City, and elsewhere, promises more uniform results in the government-developer bargaining process. In bonus zoning a developer is automatically relieved from certain zoning restrictions if he includes in his development specific features desired by the locality. ${ }^{82}$ To the extent that the terms of the bargain are identified in the ordinance, the threat of corruption and unequal treatment of prospective developers is diminished.

The inequities of zoning are not limited to its effect on landowners. Recent legal commentary about zoning has emphasized its potential as a vehicle for segregation of racial minorities and low income groups. ${ }^{83}$

77 See note 30 supra.

78 The initial application of this system involved the leasing of unused development rights over the city-owned Appellate Division Court House at Madison Avenue and 25th Street to an adjacent landowner for seventy-five years at an annual rent of $\$ 35,000$ to $\$ 50,000$. The lessee was thus able to increase the size of his planned office building by 100,000 sq. ft., or nearly one-fourth. See New York, N.Y., Zoning Resolution art. I, ch. 2, § 12-10 (1971); Costonis, The Chicago Plan: Incentive Zoning and the Preservation of Urban Landmarks, 85 HARv. L. REv. 574, 586-87 n.44 (1972).

79 See text at notes 297-312 infra.

80 See Note, supra note 32 , at $358-61$.

81 The largest New York City apartment developer, Samuel Lefrak, has asserted, "There is no zoning anymore. It's all deals." N.Y. Times, Jan. 25, 1970, § 8, at 1.

82 For a fuller exposition of this technique, see Comment, "Bonus or Incentive Zoning”-Legal Implications, 21 SYRAcuse L. REV. 895 (1970) and a number of the readings in The New Zoning (N. Marcus \& M. Groves eds. 1970).

83 See, e.g., L. Sagalyn \& G. Sternlieb, supra note 31; Lefcoe, The Public Housing Referendum Case, Zoning, and the Supreme Court, 59 CALIF. L. REv. 1384 (1971); Sager, Tight 
In highly balkanized metropolitan areas, exclusionary policies, if widespread enough, may cause substantial inefficiencies by widely separating housing for working-class families from industrial job opportunities and may be unfair to the excluded groups. Not surprisingly, small governments do seek to keep social and fiscal undesirables out of their communities entirely. ${ }^{84}$ Employing land use regulations to segregate racial groups predates the pioneering New York ordinance. Some of the earliest reported cases involving controls having the effect of zoning dealt with devices designed to set apart the Chinese in California ${ }^{85}$ and Blacks elsewhere; ${ }^{86}$ these overt racial classifications have not survived constitutional scrutiny. ${ }^{87}$

The separation of families by income, however, is still abetted by many zoning ordinances, primarily through minimum lot size, lot frontage, and floor area requirements for residences, and the total exclusion of apartments and mobile homes. ${ }^{88}$ Needless to say, income discriminations often have racial ramifications. Lawsuits attacking these practices have primarily alleged violation of equal protection and use of the police power for invalid purposes, ${ }^{89}$ with relatively little success except in Pennsylvania ${ }^{90}$ and New Jersey. ${ }^{91}$ Legislative action

Little Islands: Exclusionary Zoning, Equal Protection, and the Indigent, 21 STAN. L. Rev. 767 (1969); Note, Exclusionary Zoning and Equal Protection, 84 HARv. L. Rev. 1645 (1971); Note, Large Lot Zoning, 78 YALE L.J. 1418 (1969); Note, The Constitutionality of Local Zoning, 79 Yale L.J. 896 (1970); Note, The Equal Protection Clause and Exclusionary Zoning after Valtierra and Dandridge, 81 YALE L.J. 61 (1971).

84 Two recent Presidential commissions have sharply attacked this exclusionary use of zoning. Building the American City, supra note 4, at 7, 19-20, 211-17; President's Committee on Urban Housing, A Decent Home 4, 25, 140, 142-44 (1968).

85 Yick Wo v. Hopkins, 118 U.S. 356 (1886); Soon Hing v. Crowley, 113 U.S. 703 (1885);

Barbier v. Connolly, 113 U.S. 27 (1885); In re Lee Sing, 43 F. 359 (C.C.N.D. Cal. 1890).

86 See, e.g., Buchanan v. Warley, 245 U.S. 60 (1917); State v. Gurry, 121 Md. 534, 88 A. 546 (1913); Harden v. City of Atlanta, 147 Ga. 248, 93 S.E. 401 (1917).

87 Buchanan v. Warley, 245 U.S. 60 (1917). Buchanan held that a Louisville, Ky., ordinance barring property sales to Blacks on blocks where a majority of existing residents were White, deprived potential White transferors of due process. Today, the same result would probably be grounded on the equal protection clause.

88 For a review of the cases on these generally lawful techniques, see sources cited in note 83 supra. A. MANvEL, supra note 36 , is the best source on the incidence of these practices. His data disclose, for example, that 45 percent of all zoning governments impose some sort of minimum floor area requirements and 13 percent wholly bar apartments. Id. at 10-11.

89 For a provocative attempt to develop a different attack, see Comment, Right to Travel: Another Constitutional Standard for Local Land Use Regulations?, 39 U. CHI. L. Rev. 612 (1972).

90 The leading Pennsylvania cases hold that exclusionary objectives are not permissible under the police power. Appeal of Kit-Mar Builders, 439 Pa. 466, 268 A.2d 765 (1970) (two- and three-acre minimum lot sizes invalid); Appeal of Girsh, $437 \mathrm{~Pa} .237,263 \mathrm{~A} .2 \mathrm{~d}$ 395 (1970) (total exclusion of apartments invalid); National Land \& Inv. Co. v. Kohn, 419 Pa. 504, 215 A.2d 597 (1965) (four acre minimum lot size invalid).

91 The New Jersey cases, however, are not grounded on the misuse of the police 
to deal with exclusionary zoning has been taken only in Massachusetts ${ }^{92}$ and California. ${ }^{93}$

In the United States zoning generally works to the detriment of the poor and near-poor, racial minorities, and renters; ${ }^{94}$ it operates for the benefit of the well-to-do, particularly homeowners, by artificially increasing the supply of sites on the market usable only for expensive homes and thus reducing their cost. ${ }^{95}$ The City of Los Angeles in effect prohibits its citizens of average income or less, and all would-be apartment dwellers, from living in the Santa Monica Mountains by restricting land use there to single-family homes on large lots. Market forces might have caused the Mountains to be inhabited primarily by the well-to-do, but not as exclusively so.

\section{Reforming Zoning}

The problems just illustrated have not won zoning many friends other than the 9,000 governments that employ it. Most critics of zoning focus their attack on specific flaws. Jane Jacobs primarily attacked

power. See Oakwood at Madison, Inc. v. Township of Madison, 117 N.J. Super. 11, 283 A.2d 353 (1971) (exclusionary zoning pattern invalid under state enabling act for failing to promote a balanced community in accordance with the general welfare); Molino v. Mayor and Council, 116 N.J. Super. 193, 281 A.2d 401 (1971) (garden apartment ordinance designed in part to exclude school children violates larger families' rights to equal protection).

92 The Zoning Appeals Act authorizes developers who are denied local approval to build subsidized housing to appeal that decision to a state agency. The decision is then reviewed under three statutory criteria: (1) regional housing needs, (2) traditional local planning standards for residential development, and (3) whether the locality has already accepted its annual, or total, quota of subsidized housing. Mass. Gen. Laws ANN. ch. 408, $\S \S 20-23$ (Supp. 1971). The Act survived constitutional challenge in Board of Appeals v. Housing Appeals Comm'n., 294 N.E.2d 393 (Mass. 1973).

93 The California statute prohibits consideration of ethnic or religious factors, or the presence of housing subsidies, in zoning decisions. CaL. Gov'T CodE $§ 65008$ (West Supp. 1972).

94 Siegan concluded that tenants are better off in Houston than they would be in zoned communities. Siegan, Non-Zoning, supra note 2, at 121. Zoning can also be used to harass persons with unpopular political ideas or living styles. See, e.g., J. Didron, Slouching Towards Bethlehem 42-60 (1968) (describing Joan Baez's problems in opening an Institute for the Study of Nonviolence in Monterey County California); Note, Excluding the Commune from Suburbia: The Use of Zoning for Social Control, 23 Hastings L.J. 1459 (1972).

95 See President's Committee on Urban Housing, supra note 84, at 143: "In some instances so-called snob zoning may in fact so increase the supply of such high-quality sites that land prices for rich house-buyers are reduced." One econometric study of land markets in the Boston area, generally finding that zoning had little impact on market allocation of residential occupancy, found its most systematic effect was the advantages it brought high income households. L. Orr, Municipal Government Policy and the Location of Population and Industry in a Metropolitan Area: An Econometric Study, 112 16 (1967) (unpublished Ph.D. thesis on file in M.I.T. library). Orr's use of the "smallest permitted residential lot-size" as the indicator to measure the exclusivity of a town's zon- 
zoning's lack of flexibility while ignoring, for example, the compensation problem. ${ }^{96}$ Civil rights groups are disturbed by the exclusionary use of zoning, but rarely condemn the resulting efficiency losses. Without an overall framework for evaluating land use control systems, critics may propose reforms that sensibly ameliorate their particular concerns, but exacerbate other problems. For example, a suggestion to upgrade the staff and procedures of the land planning structure ${ }^{97}$ is sound only if the benefit from these changes will exceed the required increase in administrative costs. Similarly, more frequent compensation for losses inflicted by zoning decisions ${ }^{98}$ will solve equity problems and tend to make planners more concerned about efficiency, but again at the expense of increased administrative costs. Shifting land use planning power to state or regional units ${ }^{99}$ would reduce the present evils of parochialism and balkanization, but larger units are less responsive and less locally knowledgeable than smaller ones and may draft cruder ordinances. A tiered system, with the state handling statewide issues and localities handling local issues, is possible, ${ }^{100}$ but increased costs of defining and policing jurisdictional limits would result. Whether any of these narrow reforms is sound depends ultimately on the relative size of the efficiency gains and losses and the effect of the reform on the fairness of the system.

Most of the zoning reforms that have been proposed do not address the three fundamental weaknesses of the institution: (1) exclusive reliance on mandatory public standards, (2) concentration on prospective development with little attention to existing land use problems, and (3) sharp and frequent variability of regulations among zones.

1. The Inefficiency of Mandatory Public Standards. Compliance with zoning laws is mandatory. Potential violators are denied permits; existing violators, unless specially protected, may be forced to comply with zoning standards through mandatory injunctions. Zoning is thus an

ing seems crude, however, and may cast doubt on his findings. See also Branfman, Cohen \& Trubeck, Measuring the Invisible Wall: Land Use Controls and the Residential Patterns of the Poor, 82 YALE L.J. 483 (1973).

96 J. Jacobs, Death and Life of Great American Cities (Vintage ed. 1961); cf. Mixon, Jane Jacobs and the Law-Zoning for Diversity Examined, 62 Nw. U.L. Rev. 314 (1967).

97 See, e.g., Wexler, "A Zoning Ordinance is No Better than Its Administration"-A Platitude Proved, 1 John Marshall J. of Practice and Proc. 74 (1967).

98 R. Babcock, The Zoning Game 169-70 (1966); Dunham, supra note 6, at 36-37; cf. Kansas City v. Kindle, 446 S.W.2d 807 (Mo. 1969) (upholding the legality of such compensation plans).

99 The National Commission on Urban Problems has recommended that the states transfer to counties the zoning power of cities under 25,000 in population. BuiLding THE AMERICAN City, supra note 4, at 236.

100 A system of this type is proposed in articles 7 and 8 of the Model Land DevelopMent Code (Tent. Draft No. 3, 1971). 
example of what Calabresi terms a system of specific deterrence. ${ }^{101}$ Specific deterrence systems impair the efficiency of resource allocation to the extent that they require compliance with a standard even when the prevention costs involved in compliance exceed the resulting reduction in nuisance costs. The inadequacies of the information ${ }^{102}$ and staff ${ }^{103}$ available to existing governmental planning agencies create doubts about their ability to evaluate and weigh prevention and nuisance costs correctly. This element of inefficiency would be lessened if the sanction for a zoning violation were limited to a fine or an award of damages keyed to the amount of nuisance costs resulting from lack of compliance. An enterprise could then choose to violate an inefficient standard, pay the monetary penalty, and escape a higher level of prevention costs. Enforcement through carefully calculated monetary penalties is more like what Calabresi calls a system of general deterrence, where all activities are permitted if they pay for their external costs. ${ }^{104}$

101 G. Calabresi, Cost of Accidents, supra note 11, at 95-106. Another example of specific deterrence is injunctive relief in a nuisance action.

102 The urban critic's suburban nightmare of boxlike houses in the middle of identical cookie-cutter lots is not only a product of unimaginative builders, but also of regulations drafted by persons unable to predict the effects of their acts and with classifications so crude that they deprived landowners of most of their flexibility. The inherent threat of zoning to diversity has been powerfully portrayed by Jane Jacobs. J. JAcoBs, supra note 96 at 222-38; cf. Mixon, supra note 96 . The difficulty of obtaining adequate information for sophisticated collective planning has become painfully apparent in the last few decades. In the past, professional city planners believed that efficient land development could be promoted through a long-term comprehensive plan. The master planners soon found, however, that they could not learn enough at reasonable cost to prepare, and keep up-to-date, long-term plans of any detail. Thus, long-range comprehensive planning is currently in disrepute with large segments of the planning profession. This skepticism has given birth to an important school of planning thought that asserts that government can at best "muddle through" its problems, defusing crises as they arise, but doing little else. For a short review of the literature debating the merits of long-term and short-term planning efforts, see Model Land Development Code 87-94 (Tent. Draft No. 2, 1970).

103 Public land regulation is difficult enough when attempted by the most expert. In the United States, land planning is largely in the hands of low-level professionals and rank amateurs. Planning commissions and Boards of Zoning Appeals are usually manned with untrained political appointees; the performance of these bodies is heavily criticized in the literature. Building the American City, supra note 4, at 238-39; Shapiro, supra note 74, at 18; Note, Administrative Discretion in Zoning, 82 Harv. L. Rev. 668, 674-75 (1969).

Pay scales for employees who administer public land use regulations are low relative to the power they exercise. At the end of 1967, every metropolitan municipal government with a population under 10,000 paid its top professional planner no more than $\$ 15,000$ annually, and 60 percent of these municipalities had no full-time planning employees. A. Manvel, supra note 36 , at 26 . The average annual salary for full-time professional and technical employees of planning and zoning agencies of municipalities over 5,000 population was about $\$ 9,000$ in 1967 . Id. at 30 .

104 G. Calabresi, Cost of Accidents, supra note 11, at 68-77. 
Many land use problems now governed by specific deterrence systems probably would be better handled with general deterrence systems. In Euclid, ${ }^{105}$ the village's decision to plan its community cost the Ambler Realty Company over $\$ 300,000$. Undoubtedly, that amount is far more than that required to install the finest landscaping along Euclid Avenue or compensate nearby property owners for the losses caused by an industrial use. Allowing Ambler Realty to landscape or compensate would probably have been a more efficient solution to the external cost problem, but that course was precluded by Euclid's mandatory standards.

Reliance on mandatory standards instead of more decentralized systems tends to magnify the costs arising from the inherent crudeness of government. Local legislatures often enact inefficient ordinances, mainly because of the failure of electoral systems to weigh the intensity of voter preference, ${ }^{106}$ the prohibition of voting by nonresidents affected by a jurisdiction's legislation, and differences in organization costs faced by interest groups that might lobby on legislative issues. ${ }^{107}$ Greater reliance on general deterrence systems is one means of dealing with these difficulties since mistakes in penalty systems are apt to be less costly than mistakes in mandatory systems. ${ }^{108}$ The inefficiencies of mandatory controls would be considerably reduced if zoning prohibitions could be lifted by damage payments. The economic and political pressures unleashed by inefficient regulations have already caused some movement in that direction. Flexibility devices prominent in the zoning field in the last decade, like conditional use permits, contract zoning, and planned unit development (PUD), are actually vehicles by which local governments agree to waive inefficient standards when offered a sufficiently attractive package of donations and preventive measures. ${ }^{109}$

PUD, now employed by a majority of zoning municipalities, ${ }^{110}$ is the most important of these flexibility devices. Since local governments using PUD retain the right of ultimate approval of a subdivider's comprehensive development map, they are able to consider individual cases

\footnotetext{
105 Village of Euclid v. Ambler Realty Co., 272 U.S. 365 (1926).

106 For discussion of the logrolling behavior of legislatures that introduces elements of intensity of preference in majority rule voting systems, see J. Buchanan \& G. Tullock, The Calculus of Consent 125-26, 131-45 (1962).

107 Judicial decrees may be even more unreliable. See note 215 infra.

108 See text at notes 297-312 and note 306 infra.

109 For a sampling of techniques used to loosen Euclidean zoning, see G. LEFCOE, LAND DeVelopment 1292-1345 (1966). Cf. Note, supra note 103.

11045 percent of the zoning governments responding to the Manvel survey claimed their ordinances permitted PUD developments. A. MANvel, supra note 36 , at 10 . The percentage has undoubtedly increased since that survey was taken in 1967.
} 
and, where appropriate, to lift rigid restrictions. This welcome loosening of the strait jacket of zoning, however, is not without drawbacks. Case-by-case decision making substantially increases administrative costs by requiring ad hoc public hearings to consider the proposed development. In addition, the case law of zoning indicates that most courts will decline to police PUD administration carefully, apparently because they have decided their judicial energies are better spent elsewhere. ${ }^{111}$ As a result, the use of flexibility devices inevitably enhances the probability of arbitrariness and special dealing.

The possibility of arbitrariness could be reduced by shifting the power to waive mandatory land use standards from local government to the neighbors who would be damaged by the prohibited use. To the credit of the institution, many zoning decisions today are largely shaped by private bargaining between a potential developer and his neighbors. A landowner seeking a variance, conditional use permit, or zoning amendment is more likely to be successful if the affected neighbors are not opposed. Although it may appear corrupt on the surface, an excellent way to handle conflicts is to encourage the landowner to distribute monetary payments to his neighbors to enlist their support for his project. Such payments internalize the landowner's future externalities.

Formalized neighborhood voting on zoning changes has been attempted; ${ }^{112}$ in Detroit, a recent ordinance subjects the location of gasoline stations to such a vote. ${ }^{113}$ Under this ordinance, no station can be built within 400 feet of any residentially zoned property without the written consent of 60 percent of the residential property owners within 500 feet of the proposed station. If the would-be station owner bought the votes of affected neighbors with cash payments, the system could alleviate the equity problems raised by traditional zoning; further, the sum of nuisance and prevention costs would tend to be minimized since entrepreneurs would design their stations to reduce

111 But see note 75 supra.

112 Neighborhood voting has long played a role in the zoning process. Section 5 of the Standard State Zoning Enabling Act provided that if 20 percent of the landowners in a defined "neighborhood" near a proposed zoning change protested the amendment, a three-fourths majority was needed to carry the amendment in the local governing body. Reprinted at Model Land Development Code 210-21 (Tent. Draft No. 1, 1968). See, e.g., Appeal of Perrin, 305 Pa. 42, 156 A. 305 (1931), where a neighborhood voting scheme affected the location of gasoline stations. The legality of the delegation of governmental power to informal groups has been muddied by some United States Supreme Court decisions early in this century. See F. Michflman \& T. Sandalow, Government in Urban AREAS 111-55 (1970).

113 Detroit, Mich., Ordinance 572-G, Feb. 23, 1971, and Ordinance 599-6, June 29, 1971. 
the losses suffered by neighbors. The effectiveness of the Detroit ordinance is limited to the extent that the oil company may avoid full internalization by obtaining the requisite 60 percent from the property owners living farthest from the station because their harm is least and their vote is therefore cheapest.

Perhaps because of this shortcoming, most voting systems do not fully delegate the power to waive preexisting land use standards to neighboring landowners. In Detroit, for example, construction of a gas station also requires permissive zoning. If the voting system were modified, however, so that its dynamics would necessarily internalize the external costs to the most seriously affected neighbors, the requirement of legislative approval would be superfluous. ${ }^{114}$ If it is possible to define the class of people primarily concerned with whether the gas station is built, efficiency can be achieved without government interference with the neighborhood decision.

Whether neighborhood voting schemes improve the zoning process ultimately depends primarily upon the administrative costs of holding special elections. Again, the primary advantages of such systems are reduced likelihood of favoritism and probable compensation for harm through the purchase of votes. Despite these attractive features, voting systems may involve prohibitively high administrative costs for all but the most local externality problems; ${ }^{115}$ the costs of private bargaining and election supervision increase greatly as the electorate grows in size. In general, major zoning liberalizations are probably more efficiently, if not more fairly, sold by established governmental units.

Like neighborhood sales, governmental sales of waivers of land use regulations involve high administrative costs if every case is dealt with on an ad hoc basis. These costs could be diminished, however, by setting uniform sales prices for waivers, preferably equal to the average damage resulting from violation of the standards to be waived. When irrevocable offers are made at these sales prices, the mandatory regulations approach evolves into a general deterrence system; standards are enforced only through payments having the effect of fines. Fines, mandatory standards, and other systems for handling pervasive external cost problems will be further analyzed later. ${ }^{116}$

114 Otto Davis, who has proposed increased use of voting systems in zoning, would solve this problem by requiring unanimous consent of adjoining property owners. Davis, supra note 2 , at 386 .

115 In these localized situations, nuisance law is apt to be a better remedy than a voting system since it eliminates problems caused by holdouts and hypersensitive neighbors. Cf. text at notes 269-96 infra.

116 See text at notes 297-318 infra. 
2. The Problem of Scant Retrospective Application. Since the application of zoning regulations to preenactment land uses is politically unpopular, the first zoning map drawn in a jurisdiction will closely mirror existing land uses. The main thrust of the regulations thus focuses on the prospective development of vacant land. ${ }^{117}$ Zoning is forced into a "hands off" attitude toward most existing nuisances because it is mandatory and extinction is usually both politically undesirable and an inefficient remedy. Zoning's incapacity to deal with existing land use problems severely limits its effectiveness.

3. The Inequity of Multiple Zones. The variability of restrictions on topographically identical parcels of land is the third fundamental weakness of zoning systems. The growing number of zones in most cities reflects an attempt to refine an increasingly precise hierarchy of land uses ranked according to their levels of nuisance costs. The efficiency of this additional complexity is a close question, but largely irrelevant. The main point is that nonuniform regulation by local government is almost inevitably unfair regulation. The amounts of money at stake in switching parcels of land from one zone to another assure that zoning will continue to be an arbitrary and largely corrupt system. In addition, as long as multiple residential zones are tolerated, zoning will tend to be used to segregate the residences of different income classes and thus restrict equality of opportunity.

With the inherent shortcomings of zoning as a backdrop, this analysis now turns to the fundamental issues that underlie land use conflictsthe proper distribution of rights among landowners and optimal systems for their enforcement. That investigation will lead to the construction of an alternative model to zoning that alleviates the impact of the three problems just discussed without causing greater ones.

\section{Covenants, Merger, and Other Consensual Systems of Land Use Regulation}

The construction of a more privatized land use control system begins with an examination of the implications of a laissez faire distribution of property rights. In that imaginary legal world, landowners would be free to use their land in any manner without fear of legal consequence. The government in such a society would provide a collective system for enforcement of privately negotiated agreements, but would itself

117 This limitation is not total; certain localities do make an effort to phase out nonconforming uses. Nonconforming lots or bulks, however, are rarely touched. The construction of the Cairo Hotel in Washington, D.C., prompted the passage of height limits, yet the building still stands after over sixty years of violating them. 
impose no standards on land use. How would a landowner be expected to act under these conditions? If good manners were not a characteristic of this society, the landowner would realize that externalities were preventing him from maximizing his welfare. He would notice that his neighbors rarely generated external benefits through activities like fine architecture or landscaping. Further, he would observe that some of his neighbors were often causing him substantial harm that could be sharply reduced by relatively minor modifications, a shade on a neighbor's bright light, a filter on his smokestack, or a fence around his junkyard.

Following the realization that some internalization device would tend to enhance their welfare, landowners can be expected to try two types of voluntary transactions, merger and the partial exchange of rights. A merger is effected when a landowner is prompted to buy his neighbor's land in fee simple absolute. If there are no financing problems, this outcome is likely where the administrative costs of acquisition and unilateral rule making are less than the costs of bargaining for and enforcing a more limited exchange of rights. Merger is often the device used by a landowner to internalize his own beneficial externalities, ${ }^{118}$ perhaps because the present legal system fails to provide any reliable alternative method of internalizing such spillovers. ${ }^{119}$ Good examples of internalization through merger are the "new town" developments recently undertaken by private land developers. ${ }^{120}$ The entrepreneur places improvements such as golf courses, lakes, and community centers near the center of his holding; ownership of the surrounding land allows the developer to internalize the increases in adjacent land values that result from the improvements. ${ }^{121}$

118 Merger also internalizes harmful externalities. See, e.g., Crocker, Externalities, Property Rights, and Transactions Costs: An Empirical Study, 14 J. LAw \& EcoN. 451 (1971). Crocker relates that phosphate mines in Florida bought neighboring lands to avoid threats by the state to impose emission controls.

119 Freeloading is likely when numerous parties would be benefited by another's unsolicited activity, and it arises because of restrictions on recovery for unjust enrichment. The voluntary formation of merchants' associations to provide parking facilities for a shopping area or decorations during holiday seasons indicates that freeloader problems may occasionally be overcome.

120 In practice, large land assembly efforts are unlikely to be completely successful. Even where the land assembler has disguised his efforts through the use of nominees, most "new towns" contain some parcels owned by persons who refused to convey. For a description of the methods used by a commercial developer in Houston in a largely successful attempt to buy out hundreds of nearby homeowners, see B. SiEgan, LAND UsE Without ZoNiNG 127-28 (1972). Merger of fractionated land holdings through granting a narrowly limited power to large developers to condemn out-parcels at a substantial bonus over fair market value might be desirable in light of possible efficiency gains. This policy would lower the administrative costs of land assembly, but might also violate the public use restriction on the eminent domain power as now interpreted in many jurisdictions.

121 The Disney organization became aware of the benefits of merger through painful 
The neighboring owners may decide not to merge but rather negotiate a lesser exchange of rights, enforcing the exchange through mechanisms provided by the government. For some consideration, a landowner might submit to restrictions on the use of his land or agree to be bound by affirmative obligations to carry out specific activities like mowing grass or maintaining a fence. ${ }^{122}$ Existing property law provides for enforcement of many agreements of this type, including covenants, leases, easements, and defeasible fees. Covenants serve as a representative example of these consensual transactions between landowners; this category encompasses affirmative and negative obligations and is perhaps the most prevalent type of private agreement between neighbors.

Covenants negotiated between landowners will tend to optimize resource allocation among them. ${ }^{123}$ In other words, the reduction in future nuisance costs to each party will exceed the sum of the prevention and administrative costs each agrees to bear, with all costs discounted to present value. For example, when a developer drafts covenants that will bind people who move into his subdivision, market forces prompt him to draft efficient ones. Covenants will enhance the developer's profit only if they increase his land values by more than the cost of imposing them. His land values will rise only if his home buyers perceive that the covenants will reduce the future nuisance costs they might suffer by an amount greater than the sum of their loss of flexibility in use and future administrative costs. The developer will suggest, therefore, only those covenants that provide each purchaser with a reduction of nuisance costs greater than the purchaser's loss in flexibility plus his

experience. The original Disneyland in Anaheim, California, was constructed on a relatively small land holding and was immediately surrounded by commercial uses that took advantage of the trade Disneyland created. In 1968, the businesses surrounding Disneyland had gross sales five times the sales of Disneyland. For the Walt Disney World in Florida, the corporation thus assembled a land holding more than 100 times the size of the California park; the benefits of this Florida tourist attraction were then systematically internalized. Walt Disney Productions, Annual Report for Fiscal Year Ending September 28, 1968, at 6 .

122 The great bulk of covenants, however, are negative, promising restraint from specified behavior. This pattern indicates that landowners feel that affirmative obligations are likely to be inefficient, perhaps because these agreements are expensive to enforce or because landowners fear a substantial drop in the value of their property from such encumbrances. In addition, property law has been hostile to the running of affirmative duties to succeeding owners. Finally, where affirmative covenants are enforceable, they are often not enforced in practice. The largest merchant homebuilder in the United States, Levitt \& Sons, Inc., requires homeowners to covenant to mow and weed their lawns weekly during the summer months. The author's field experience as a Levitt employee indicates that these covenants are not enforced by Levitt or its homebuyers.

123 This analysis assumes that landowners are capable of rational economic decisions. For a critique of this assumption, see Heymann, The Problem of Coordination: Bargaining and Rules, 86 HARv. L. REv. 797, 805-13 (1973). 
enforcement cost plus a pro rata share of the developer's administrative costs. Not all conflicts between neighbors can be solved by covenants, but covenants generated by market forces will tend to promote efficiency.

In addition to promoting efficiency, covenants will not usually cause unfair wealth transfers among landowners. Absent fraud, duress, and the like, a party will not agree to a contract that he perceives as unfair. Thus, assuming equal bargaining power and information, consensual covenants will not involve inequitable gains or losses to any party.

Covenants cause problems, however, when they impose external costs on third parties, creating suboptimal resource allocation and unfairness. The classic American example of this nature was the widespread use of covenants to prevent the sale of residential property to Blacks. Restrictive racial covenants, particularly when widespread, impose opportunity costs on Black home buyers by restricting their market. More difficult to measure, but unquestionably present, are the costs of segregation to society in general. Anti-Black covenants are unfair because they single out a small population group for permanent exclusion; the inequity is compounded because Blacks have suffered from other artificially imposed disadvantages. The courts understandably struck down such agreements on constitutional or public policy grounds. ${ }^{124}$

Today, restrictive covenants are widely used as a device to exclude lower income groups. ${ }^{125}$ For example, most subdivisions use private covenants to provide assurance of style, tone, and nonentry of the less fortunate. Even the Pennsylvania Supreme Court, noted for its hostility to all forms of exclusionary zoning, has tolerated a wide range of nonracial exclusionary covenants. ${ }^{126}$

Two factors indicate that such covenants deserve greater judicial tolerance than racial covenants or mandatory regulations that promote

124 See Hurd v. Hodge, 334 U.S. 24 (1948); Shelley v. Kraemer, 334 U.S. 1 (1948). Whether narrowly drawn covenants to protect ethnic neighborhoods should also be illegal is a more difficult question.

125 This is generally accomplished indirectly through lot size requirements, house size requirements, and similar provisions.

126 What basically appears to bother intervenors is that a small number of lovely old homes will have to start keeping company with a growing number of smaller, less expensive, more densely located houses. It is clear, however, that the general welfare is not fostered or promoted by a zoning ordinance designed to be exclusive and exclusionary. But this does not mean that individual action is foreclosed. "An owner of land may constitutionally make his property as large and as private or secluded or exclusive as he desires and his purse can afford. He may, for example, singly or with his neighbors, purchase sufficient neighboring land to protect and preserve by restrictions in deeds or by covenants inter se, the privacy, a minimum acreage, the quiet, peaceful atmosphere and the tone and character of the community which existed when he or they moved there."

National Land \& Inv. Co. v. Kohn, 419 Pa. 504, 533, 215 A.2d 597, 612 (1965), quoting in part Bilbar Const. Co. v. Easttown Twp. Bd. of Adjustment, 393 Pa. 62, 94, 141 A.2d 851, 867 (1958) (dissenting opinion). 
segregation by income class. First, racial covenants define the excluded class in a way that permits no escape. By contrast, to the extent that any member of an excluded economic class can potentially increase his income, an economic exclusion is not permanent. ${ }^{127}$ In addition, a cost-benefit evaluation of noncollective efforts to exclude by income class is likely to be more favorable than a similar evaluation of legislatively mandated income exclusion. The external costs most economic covenants impose on lower income groups are minor because the covenants tie up only a small amount of land for a few decades. If those who are excluded recognize both the low cost of such exclusion and the possibility of a change in their own status, they may then perceive that the efficiencies made possible by allowing income-restrictive covenants are so great that upholding such covenants is in their long-term selfinterest.

Economic restrictions become less fair as interference with immediate residential opportunities becomes substantial. If land developers imposing economic covenants have considerable monopoly power in their regional markets, a decision to exclude low income families will impose serious opportunity costs on those families. In such cases, income-restrictive covenants should be denied enforcement on the grounds of the inequity of inflicting these losses on low income families and the inefficiency of the high prevention costs created. In this country, however, such monopoly power is probably quite rare given the wide distribution of urban land ownership. For example, if a proposed uniform set of restrictions to single-family use were circulated for signature among landowners in the Santa Monica Mountains, many would refuse to sign, opting instead for freedom to devote their holdings to more dense residential development in the future. Zoning is clearly more effective than restrictive covenants in achieving class exclusions.

Whatever their purpose, the use of covenants as an internalization device in land markets has been limited by unfathomable judicial restrictions rooted in the Middle Ages. ${ }^{128}$ The process of urban development in California will illustrate the effect of this judicial hostility. Early California decisions consistently expressed reluctance to enforce covenants against succeeding owners, even when the party

127 But see text at notes 238-40 infra.

128 For much fuller treatment of covenant law, see C. CLARK, Covenants and InTEREsts Running with Land (2d ed. 1947); Berger, A Policy Analysis of Promises Respecting the Use of Land, 55 Minn. L. Rev. 167 (1970); Dunham, Promises Respecting the Use of Land, 8 J. LAw \& Econ. 133 (1965). For a multinational perspective, see McCarthy, The Enforcement of Restrictive Covenants in France and Belgium: Judicial Discretion and Urban Planning, 73 Colum. L. REv. 1 (1973). 
acquiring the burdened parcel had record notice of the restrictions. ${ }^{129}$ Subsequently, California statutes governing validity of covenants were narrowly construed to restrict the running of burdens; ${ }^{130}$ California courts have also readily terminated covenants on the grounds of changes in neighborhood conditions. ${ }^{131}$ Judicial hostility toward covenants in the early part of this century undoubtedly aggravated problems of external costs in urban land markets, thus providing fuel for proponents of zoning. By seeking to protect landowners from entangling covenants, the courts unintentionally encouraged the development of public regulations imposing much greater restraints on the free use of land. The present judicial attitude fortunately seems to favor elimination of these unnecessary barriers to bargaining among neighbors. ${ }^{132}$

One less artificial limitation on the greater use of covenants is high administrative costs. Standard forms ${ }^{133}$ could reduce drafting costs to parties and information costs to participants in land markets, who now must decipher private land use restrictions. ${ }^{134}$ Information costs could also be reduced by simplifying, through modernization of the indexing of land records, the process of finding the covenants applicable to a specific parcel. More definite exposition of termination doctrines might also reduce administrative costs. When a common covenant scheme governs many parcels, high administrative costs may prevent landowners from organizing to terminate the scheme even though the prevention costs of the scheme exceed its reduction in nuisance costs. Courts have attempted to solve this problem by terminating these covenants where

129 Werner v. Graham, 181 Cal. 174, 183 P. 945 (1919); Berryman v. Hotel Savoy Co., 160 Cal. 559, 117 P. 677 (1911); Los Angeles Terminal Land Co. v. Muir, 136 Cal. 36, 68 P. 308 (1902).

130 See, e.g., Marra v. Aetna Const. Co., 15 Cal. 2d 375, 101 P.2d 490 (1940) (construing Cal. Civil Code $\S \S 1461-70$ ). Section 1468 was substantially amended by Cal. Stats. 1968, ch. $680 \S 1$, and Cal. Stats. 1969, ch. $245, \S 1$ to liberalize the running of burdens. CaL. Civil Code § 1468 (Supp. 1973). See Comment, Covenants: California's New Legislative Approach to Covenants Running with the Land, 9 SANTA CLARA LAWYER 285 (1969).

131 See, e.g., Key v. McCabe, 54 Cal. 2d 736, 8 Cal. Rptr. 425, 356 P.2d 169 (1960); Wolff v. Fallon, 44 Cal. 2d 695, 284 P.2d 802 (1955); Downs v. Kroeger 200 Cal. 743, 254 P. 1101 (1927).

132 See, e.g., Nicholson v. 300 Broadway Realty Corp., 7 N.Y.2d 240, 164 N.E.2d 832 (1959). Academicians have generally urged greater judicial tolerance of covenants through relaxation of the privity of estate requirement. See Berger, supra note 128, at 194-95; Dunham, supra note 128 , at 163-64.

133 Considerable standardization already exists. The Federal Housing Administration has a standard set of covenants that subdividers proceeding under the FHA single-family programs must use or replace with an acceptable alternative. The Veterans Administration, lenders, publishers of legal formbooks, and such nonprofit organizations as the Urban Land Institute have also contributed to the standardization of covenants.

134 The administrative advantages of standard forms must be weighed against their inflexibility. 
neighborhood conditions have changed. Liberal application of this doctrine results, however, in excessive litigation. ${ }^{135}$ State legislatures could help solve the problem by establishing standard termination procedures and maximum life spans for covenants; legislative rules would also permit courts to depart from perverse requirements such as "privity of estate" and "touch and concern" for the running of covenants. These judicially created rules are designed to prevent the accumulation of legal cobwebs on land parcels; the invocation of these rules, however, often ignores the intent of the parties. Procedures to remove stale covenants systematically after several decades would interfere less seriously with freedom of contract and tend to reduce administrative costs.

Present methods of enforcing private covenants can also be improved. If one landowner in a common covenant scheme commits a violation, each of his neighbors will be reluctant to assume enforcement costs since nothing prevents the other neighbors from freeloading on that effort. In Houston, this problem is alleviated by municipal enforcement of private covenants. ${ }^{136}$ To prevent the transfer of enforcement costs to government, a preferable solution in large subdivisions might be compulsory membership in a homeowners' association that polices the covenants and is financed by assessments on its members. ${ }^{137}$

Systems of covenants are an ideal system of land use regulation in major developments undertaken by single owners. The administrative costs involved are minimal since the developer drafts the covenants unilaterally and buyers must accept them. In such cases, public intervention is necessary only at the margins of the parcel since most nuisance problems are internalized. ${ }^{138}$ The usefulness of private order-

135 There are more reported cases on this aspect of covenant law than any other. Despite its doctrinal complications, however, the current number of cases on covenant law appears to be less than 15 percent of the cases on zoning. See note 61 supra.

136 The city can seek injunctive relief against breach of a covenant and can deny permits for commercial construction projects that would violate covenant provisions. The two programs are authorized by Tex. Rev. Civ. Stat. Ans., Art. 974 a-1 and a-2 (Supp. 1970), respectively. Houston has used these powers, over a three year period, to abate 2,300 violations and file 38 lawsuits. Siegan, Non-Zoning, supra note 2, at 77. See generally B. Siegan, Land Use Without Zoning 30-33 (1972); Comment, Houston's Invention of Necessity-An Unconstitutional Substitute for Zoning?, 21 BAYLOR L. REV. 307 (1969); Comment, The Municipal Enforcement of Deed Restrictions: An Alternative to Zoning, 9 Houston L. Rev. 816 (1972); Comment, Municipal Enforcement of Private Restrictive Covenants: An Innovation in Land-Use Control, 44 Texas L. REv. 741 (1966).

137 Although many such associations are active in Houston, they apparently police only a small minority of that city's covenant schemes. Compare B. Siegan, Land UsE Without ZoNing 33 (1972), with id. at 35.

138 When all problems are internalized by merger, government should also not interfere with the distribution of rights among those who use the single owner's land. A common 
ing in these situations is recognized, to some extent, by PUD zoning provisions. Since the land development industry is becoming increasingly dominated by larger firms, ${ }^{139}$ covenants should play a more important role in the future.

Even if covenant law were sensibly modernized, however, covenants could play only a limited role in older, established neighborhoods where land ownership is highly fractionated. ${ }^{140}$ Except for the simplest problems involving a few neighbors, land owners rarely meet as a group to draft agreements governing land use. Aside from privity of estate requirements that currently discourage such neighborhood mobilization, ${ }^{141}$ the costs of organizing many people are apparently too high, and the risk of freeloaders too great, for private bargaining to take place. ${ }^{142}$ Thus, although covenants are an attractive device, they are not feasible in many neighborhoods. To deal with harmful externalities in these areas, the original assumption of a laissez faire distribution of

landlord, for example, is in the best position, and has the incentive, to resolve any conflicts arising between his tenants. Yet, courts have at times applied the principles of nuisance law to establish tenants' rights inter se, apparently without considering their express or implied rights under their leases. A good example is the famous case of Sturges v. Bridgman, $11 \mathrm{Ch}$. D. 852 (1879), where a doctor sought to enjoin a neighboring confectioner from using noisy mortars that prevented him from examining patients in his consulting room. Both parties were lessees of the Duke of Portland; nevertheless, the court applied nuisance doctrine without regard to substance of the leases. The court in Sturges may not have enforced the rights of the tenants in the way the Duke had distributed them. If the leases did not define rights in cases of intertenant annoyance, the invocation of nuisance principles might be proper. In that case, however, it is doubtful that the doctor should recover his entire damages since his activity appears to be hypersensitive to injury, and, in addition, he came to the nuisance. See text at notes 241-68 infra. Another intertenant nuisance case ignoring lease provisions is Associated Metals and Mining Corp. v. Dixon Chem. \& Res., 82 N.J. Super. 281, 197 A.2d 569 (1963).

139 President's Committee on Urban Housing, supra note 84, at 151-52. Periodic surveys by Professional Builder magazine also confirm the trend toward greater concentration in housing production. Although solid statistics are lacking, land development, the manufacture of improved lots, is probably more concentrated than building construction. Large land developers commonly sell off improved lots to smaller companies for house construction. Both the land developer and the builder could draft covenants in such situations, but the land developer is likely to be the principal author.

140 For a more optimistic view of the potential usefulness of covenants in existing neighborhoods, see Note, Land Use Control in Metropolitan Areas: The Failure of Zoning and a Proposed Alternative, 45 S. CAL. L. REv. 335, 359-60 (1972).

141 The harshness of these requirements has been somewhat reduced by the evolution of the concept of equitable servitudes.

142 Spontaneous neighborhood mobilization is not unknown. In Houston, homeowners in subdivisions have renewed covenants that had expired through passage of time. Siegan, Non-Zoning, supra note 2, at 90-91. See also Lewis v. Gollner, 129 N.Y. 227,29 N.E. 81 (1891), where residents of a fashionable neighborhood combined to buy the land of a builder who threatened to construct a seven-story tenement. The Houston experience suggests that unanimous neighborhood action becomes less probable as the number of landowners involved increases. See B. Siegan, LANd Use Without Zoning 239-45 (1972). 
property rights must be reconsidered. Even if the initial placement of rights is altered to a different distribution, landowners can still gain by trading rights. Consensual systems like covenants are valuable tools for private adjustment of any initial rights distribution.

\section{Assigning Rights Among Landowners:}

\section{A Reformulation of Nuisance law}

More efficient and more equitable resource allocation will sometimes be achieved by altering the laissez faire distribution of property rights so as to place the risk of loss from external harms on the landowner carrying out the damaging activity. This possibility of redefining property rights is often overlooked ${ }^{143}$ because liability of landowners for external harms is thought to be inconsistent with fee simple land tenure. Common law doctrines, however, have long assigned property rights to deter unneighborly acts. At common law, landowners were held to an absolute duty to provide lateral support for their neighbors' land. ${ }^{144}$ Invasions by persons, animals, or solid matter capable of inflicting injury through the force of physical impact are actionable under trespass doctrines. The famous case of Rylands $v$. Fletcher ${ }^{145}$ imposed absolute liability for damage caused by the overflow of unnaturally gathered substances onto neighboring land. Less tangible interferences such as noise, fumes, aesthetic blight, or vibration may be handled under the law of nuisance. ${ }^{146}$ Since most potential conflicts in modern urban environments involve these less tangible interferences, nuisance law provides the most important source of common law rules for shifting the risk of loss for external harms.

\section{A. Existing Nuisance Law as a Land Use Control System}

Nuisance law is today suffering from neglect. Its doctrines receive little attention in modern casebooks on torts and property. Scholarly

143 The National Commission on Urban Problems ignored this possibility when it asserted that, in the 1920's:

[t]he buyers and sellers of lots needed some device to prevent a drop in property values, keep out unwanted intrusions, encourage investment in land and construction-in sum, to assure character. The fee simple land tenure, which gives owners a freedom of use that modern homeowners are frightened to have their neighbors possess, did not provide the needed protection. Zoning did.

Building the American City, supra note 4, at 18-19.

144 J. Cribbet, Principles of the Law of Property 292-95 (1962).

145 L.R. 3 H.L. 330 (1868).

146 One category of nuisance law deals with "public nuisances," criminal interferences with common public rights subject to abatement upon prosecution by the state. As a system of mandatory prohibitions enforced by government officials, public nuisance law was the ancestor of zoning and is a more centralized approach to external cost problems than private nuisance doctrines. 
analysis of nuisance problems has been minimal, perhaps because nuisance law is widely viewed as an archaic means of handling land use problems. As a result, the confusions and inefficiencies in the law of nuisance are considerably more serious than in most other areas of the law. ${ }^{147}$

Many of the doctrinal difficulties in nuisance law have arisen when courts have tried to avoid granting injunctive relief, the traditional remedy in nuisance cases. An injunction often imposes prevention costs that exceed the reduction in nuisance costs it achieves; the closing of a factory may be more costly to the economy than the losses caused to neighbors by its operation. As courts became sensitive to this danger they responded by limiting the circumstances in which they were willing to find a nuisance, rather than denying injunctive relief while still allowing damages. ${ }^{148}$ Nuisance law thus came to provide no relief in many cases where the risk of loss could appropriately have been shifted to the landowner carrying out the damaging activity. ${ }^{149}$

In many instances courts avoided finding actionable nuisances by applying a type of balancing test; the social utility of the actor's conduct was compared to the total amount of harm caused. This test is proper for deciding whether to grant injunctive relief. Unfortunately most courts applied the test to the initial question of whether a nuisance existed at all, ${ }^{150}$ incorrectly limiting the availability of damage awards

147 "There is perhaps no more impenetrable jungle in the entire law than that which surrounds the word 'nuisance.'” W. Prosser, Handbook on TorTs, § 86, at 571 (4th ed. 1971) [hereinafter cited as W. Prosser, Torts].

148 A good example is the case of Bove v. Donner-Hanna Coke Corp., 236 App. Div. 37, 258 N.Y.S. 229 (1932). The defendant's coke oven emitted air pollutants that gave plaintiff headaches and caused her to keep some of her windows closed to reduce the soot level in her home. Proof of substantial damage from a nuisance gave rise to an absolute right to injunctive relief under New York law. See, e.g., Whalen v. Union Bag \& Paper Co., 208 N.Y. 1, 101 N.E. 805 (1913). Although the nuisance was apparent, recognizing it would have resulted in shutting down a major manufacturing facility during the depths of the depression. The court was able to refuse injunctive relief only by an analysis that also kept it from awarding damages. It avoided finding a nuisance on the grounds that the plaintiff had "come to the nuisance" and the defendant was shielded by permissive zoning; neither defense was justified by the facts of the case. Bove thus shows the doctrinal confusion caused by the liberal availability of injunctive relief. A recent New York case has eliminated the court's dilemma in Bove by holding that injunctive relief would henceforth be discretionary in nuisance cases. Boomer v. Atlantic Cement Co., 26 N.Y.2d 219, 257 N.E.2d 870 (1970).

149 For example, most courts denied all relief in cases of aesthetic blight. Injunctive relief against aesthetic harm is generally mistaken because the damage is usually slight. It is not clear, however, why damages should not be allowed. See text at notes 181-90 infra.

150 W. Prosser, Torts, supra note $147, \S 89$ at 596-602. See also Restatement of Torts $\S \S 822$ (d) \& (i), 826 (1939); Restatement (Second) of Torts §§ 822(a), 826 (Tent. Draft No. $16,1970)$. The Restatement sections state that the defendant should not be liable under a nuisance theory if the utility of the defendant's conduct outweighs the gravity of the harm. 
that would internalize the harmful externalities. That a grocery in the Santa Monica Mountains is shown to have high utility is a good reason to refuse to enjoin its construction, but it is not good grounds for allowing it to avoid paying for its external costs. Illogical doctrines of this type have greatly reduced the value of nuisance law as a land use control system.

The use of nuisance law reached a height in the United States during the 1920's and 1930's as landowners invoked it to relieve actual or threatened noxious uses in their neighborhoods, ${ }^{151}$ with gas stations ${ }^{152}$ and funeral parlors ${ }^{153}$ generating the greatest volume of cases. In virtually all of these cases the plaintiff asked for only injunctive relief; damages were sought only from a government, charity, public utility, or other defendant against whom courts would not be likely to issue an injunction. ${ }^{154}$ The courts were thus forced to make difficult all-ornothing decisions about whether a particular use should be allowed to continue. ${ }^{155}$

Because courts had so limited their remedy options, one party was

These sections apply to damage actions as well as to suits for injunctive relief. At the suggestion of Professor Fleming James, however, new comments were added implying that the balancing test should not deprive a plaintiff of compensation when he suffers serious harm. See the newly added comments at $i d$. \$ 826-27 (Tent. Draft No. 17, 1971).

151 See Annot., 33 A.L.R. 725 (1924) (amusement park); Annot., 50 A.L.R. 107 (1927) (garage); Annot., 48 A.L.R. 518 (1927) (pesthouse); Annot., 86 A.L.R. 998 (1933) (bakery); Annot., 90 A.L.R. 1207 (1934) (industrial plant); Annot., 110 A.L.R. 1461 (1937) (automobile wrecker); Annot., 153 A.L.R. 972 (1944) (medical clinic); Annot., 22 A.L.R.2d 774, 801-02 (1952) (trailer camp); Annot., 27 A.L.R.2d 1249 (1953) (private school); Annot., 44 A.L.R.2d 1381 (1955) (dance hall); Annot., 50 A.L.R.2d 1324 (1956) (cemetery); Annot., 68 A.L.R.2d 1331 (1959) (golf course or driving range); Annot., 86 A.L.R.2d 1322 (1962) (oil refinery); Annot., 92 A.L.R.2d 974 (1963) (dairy); Annot., 91 A.L.R.2d 572 (1963) (drive-in-restaurant); Annot., 93 A.L.R.2d 1171 (1964) (drive-in theater); Annot., 5 A.L.R.3d 989 (1966) (tavern); Annot., 21 A.L.R.3d 1058 (1968) (rehabilitation institutions).

152 See Annot., 7 A.L.R. 749, 771-73 (1920); Annot., 26 A.L.R. 937, 944-49 (1923); Annot., 35 A.L.R. 95 (1925); Annot., 51 A.L.R. 1224 (1927); Annot., 124 A.L.R. 383 (1940).

153 See Annot., 7 A.L.R. 749, 782 (1920); Annot., 23 A.L.R. 745 (1923); Annot., 26 A.L.R. 937, 953-54 (1923); Annot., 43 A.L.R. 1171 (1926); Annot., 87 A.L.R. 1061 (1933); Annot., 39 A.L.R.2d 1000 (1955).

154 For example, among the many appellate cases involving funeral parlors, I found only one where the plaintiff sought damages: Haan v. Heath, 161 Wash. 128, 296 P. 816 (1931) (affirming judgment of $\$ 500$ for plaintiff). This pattern was also pointed out in Beuscher \& Morrison, Judicial Zoning through Recent Nuisance Cases, 1955 WISc. L. Rev. 440,442 . On the other hand, damage actions are probably less likely to be appealed, and thus reported, than suits involving injunctive relief.

155 Particularly in the earlier cases, the plaintiffs generally sought total abatement rather than a more narrowly limited equitable decree. In the gas station cases, for example, the courts dealt with this problem by granting an injunction where the station would be located in an exclusively residential area, and denying it if the area was mixed or largely devoted to business. Compare Huddleston v. Burnett, 172 Ark. 216, 287 S.W. 1013 (1926) with Julian v. Golden Rule Oil Co., 112 Kan. 671, 212 P. 884 (1923). 
likely to be highly aggrieved whatever the trial court's decision, and appeals were common. ${ }^{156}$ Nuisance litigation thus became an expensive process. In addition, courts were hardly an expert institution for making difficult resource allocation decisions.

These administrative flaws of nuisance law combined with its doctrinal weaknesses to fuel the belief that public regulation systems such as zoning would be superior. As zoning began to flourish, nuisance law became less important. ${ }^{157}$ The decline of nuisance law is perhaps not surprising in light of its doctrinal and administrative shortcomings. If these underlying weaknesses were remedied, however, for example by curtailing availability of injunctive relief and transferring nuisance adjudications to specialized bodies, nuisance law might return to prominence as a system for internalizing external costs.

The following sections of this article contain a proposed set of rules for assigning rights among neighboring landowners. These rules try to define the subset of externalities for which the risk of loss should be shifted to the party whose activities create the externality; in some cases the proposed rules sharply diverge from current nuisance law, especially where the availability of injunctive relief has warped existing doctrine. Finally, the article suggests an administrative structure for protecting this rights distribution and analyzes the optimal employment of that structure and other devices for dealing with harmful externalities. ${ }^{158}$

\section{B. Nuisance Law: The Prima Facie Case}

In an important economic analysis of the problem of external cost, ${ }^{159}$ Professor R. H. Coase showed that if administrative costs are zero, the

156 The annotations cited in note 152 supra record that gas stations alone prompted four reported appellate cases annually during the 1920's and 1930's.

157 The number of nuisance cases has apparently declined in recent years. For example, the pages devoted to public and private nuisance cases in West's DecenNial Digest declined from 102 in 1946-56 to 78 in 1956-66; the most recent case of a landowner trying to enjoin construction of a gas station on a pure nuisance theory occurred in 1958. Phillips v. Adams, 228 Ark. 592, 309 S.W.2d 205 (1958) (injunction granted against a gas station in a residential neighborhood).

158 See text at notes 269-318 infra. The interrelationship of rights and remedies makes separate discussion rather hazardous. For example, a specific rights assignment might optimally resolve private nuisance suits for damages, but create inefficiency if applied as a constraint on legislated regulations. Nevertheless, although couched in terms of nuisance law, the ensuing discussion of the efficiency and equity issues at stake in the assignment of rights will usually assist in the assessment of more centralized internalization systems.

159 Coase, Social Cost, supra note 2. What this article calls "administrative costs" Coase defined in more limited terms and called "transaction costs." The Coase theorem has been challenged as ignoring the fact that "rational" action by those in conflict may lead to suboptimal results. Regan, The Problem of Social Cost Revisited, 15 J. LAw \& Econ. 427 (1972). The game theoretic tactics that might lead to those results, however, all depend on uncertainty, a condition foreign to Coase's world of perfect information. 
same resource allocation will result regardless of the initial distribution of rights. Assume, for example, that there is a grocery in the Santa Monica Mountains, the only external harm to the neighbors is added noise, and administrative costs are zero. The Coase theorem states that if the cost to the grocer of going out of business is less than his neighbors' gains from the reduction in noise resulting from the termination of his enterprise, the grocer will shut down regardless of the initial distribution of rights. If homeowners have the right to recover for injury caused by the noise, the grocer will choose to absorb the smaller loss of going out of business rather than pay for the damage he causes by staying open. If the law does not require the grocer to compensate the homeowners for noise, the homeowners will combine to pay the grocer to close. The grocer will agree if the bounty is larger than his losses from closing, and the homeowners will be willing to offer more than the amount of his loss if their total damage exceeds that amount.

On the other hand, when the cost to the grocer of closing exceeds the resulting benefit to the homeowners, the grocer will continue to operate. If the homeowners have the right to recover, the grocer will pay damages rather than absorb the larger costs of terminating his business. If the grocer need not pay damages, the homeowners will not pay him to adopt a more neighborly course of action, because the minimum payment he would insist on to shut down exceeds the value of the damage they are currently suffering. In brief, the Coase theorem states that private bargaining will tend to reduce the sum of nuisance and prevention costs over time, regardless of assignment of rights. ${ }^{160}$

The Coase theorem does not imply that the policy maker need not be concerned about how rights are assigned. First, as Coase reminds us, ${ }^{161}$ administrative costs in bargaining situations are not zero, and consequently the assignment of rights does affect resource allocation. Second, the policy maker cannot ignore the equities of resource dis-

160 One might think that there would be fewer groceries if they were forced to pay for their external harm, but this is not the case if administrative costs are zero. A change in the law from nonliability for noise to liability would only put out of business those groceries unable to absorb the cost of future damage judgments, but there would be no marginally profitable groceries in business. Their potential operators would prefer to accept payments from neighboring homeowners not to operate and would thus be investing their capital and entrepreneurial skills elsewhere. For a more theoretical explanation of this point, see Nutter, The Coase Theorem on Social Cost: A Footnote, 11 J. LAw \& Econ. 503 (1968). Compare Calabresi, The Decision for Accidents: An Approach to Nonfault Allocation of Costs, supra note 11, at $730 \mathrm{n} .28$, with Calabresi, Transaction Costs, Resource Allocation and Liability Rules-A Comment, supra note 11, at 67-68.

161 Coase, Social Cost, supra note 2, at 15. See also Crocker, supra note 118. 
tribution, as Coase intentionally does, ${ }^{162}$ to focus solely on the efficiency of resource allocation. Any unexpected alteration of the distribution of rights among landowners is almost certain to affect their relative shares of wealth. ${ }^{163}$ Decisions on the distribution of rights in cases of external cost thus must accommodate the complex considerations of administrative costs and fairness.

The following reformulation of nuisance law is an estimate of how rights should be distributed among neighboring landowners when these considerations are taken into account. The analysis follows a rather traditional legal mold: the development of a prima facie case, to be pleaded and proved by the injured neighbor, and the articulation of various defenses. Whether a particular issue should be an element of the prima facie case or a defense is not an easy question, but the suggested allocation should result in a reasonably efficient and fair procedural system. A tolerably burdensome prima facie case is imposed on the plaintiff to help weed out unmerited claims. The defenses are issues on which the defendant is most likely to have the best information or to be able to introduce the most credible evidence.

1. Assigning Rights To Promote Efficiency: A Preliminary General Rule. Efficient resource allocation is accomplished through the minimization of the sum of the nuisance costs, prevention costs, and administrative costs arising from land use conflicts. ${ }^{164} \mathrm{~A}$ party compelled to bear a nuisance cost can be expected to adopt all preventive measures he perceives as efficient. A measure will appear efficient to a party if its prevention cost and the administrative cost of carrying it out are less than the reduction in nuisance costs achieved. Prevention costs cannot be diminished by shifting the assignment of rights; ${ }^{165}$ those costs are only affected by technological innovation. ${ }^{166}$ Legal rules may, however, affect the administrative costs involved in the execution of a specific preventive measure. Rights should therefore be assigned to reduce administrative costs in order to increase the number of preventive measures that parties perceive to be in their self-interest. Four guidelines

162 See note 27 supra. See also Demsetz, When Does the Rule of Liability Matter?, 1 J. Legal Studies 13, 22-25 (1972).

163 See Demsetz, Wealth Distribution and the Ownership of Rights, 1 J. Legal Studies 223, 228 (1972).

164 See text at notes 23-25 supra.

165 Since prevention costs have been defined to exclude administrative factors, this statement is a tautology.

166 New combinations of resources can make available cheaper antinuisance devices. Innovation can also reduce the opportunity costs of refraining from nuisance activity by introducing new substitutes for that activity. 
can help reduce administrative costs; ${ }^{167}$ none is controlling, but each helps in assigning legal rights when other factors are neutral.

The first guideline is knowledge. It will help to assign the risk of loss to the party facing the lowest information costs. Legal rules should focus on the party who has, or can most cheaply acquire, relevant information on the risks of future nuisance costs, and who can most cheaply assess available preventive measures. The object of this guideline is minimizing expenditures of resources on information.

The second guideline is organization. It will help to place the risk of loss on the class of parties likely to have the lowest organization costs, usually the one with the fewest members. ${ }^{168}$ This assignment will reduce the costs of internal organization and policing against freeloaders that arise when many parties must negotiate the division of costs of damage payments or preventive measures.

The third guideline is control. When the risk of loss is assigned to the parties in control of the properties where the most efficient preventive actions can be taken, the administrative costs of executing the preventive measures will be reduced.

The final guideline is simplicity of rules. Other things being equal, simple rules of liability are preferable to more complex ones since they reduce the costs of determining the distribution of rights in specific cases.

These guidelines can now be used to generate rules of liability for nuisance cases. The process can begin with the following general rule of nuisance liability: if a physical change on $B$ 's property results in a diminution of the value of $A$ 's property, $B$ should have to compensate

167 Professor Calabresi's inquiries into systems for allocating the risk of losses from accidents have heavily influenced my guidelines. Calabresi's guidelines, however, are not as explicitly based on the need to reduce administrative costs. G. Calabresi, Cost of AcciDENTs, supra note 11, at 135-61. But see id. at 143-44. See also Demsetz, supra note 162, at 28. More recently, Calabresi and Hirschoff have proposed a rule of liability similar to the guidelines suggested here. They propose that a loss should be borne by the party to an accident "in the best position to make the cost-benefit analysis between accident costs and accident avoidance costs and to act on that decision once it is made." Calabresi \& Hirschoff, supra note 11 , at 1060 .

168 For a detailed analysis of the problems of group organization, see generally $\mathbf{M}$. Olson, Jr., The Logic of Collective Action (1965). There are of course mechanisms for reducing administrative costs in large groups. For example, a laissez faire distribution of rights might create demand for "nuisance insurance" as part of the package of protections offered homeowners by insurance companies. If one company insured most of the houses in a given area, a situation not difficult to achieve in a new subdivision, it could bargain on a one-to-one basis with the party causing damage to modify his course of action, thus greatly reducing the administrative costs of homeowner organization. For a proposal on homeowners' equity insurance, see Yarmolinsky, Reassuring the Small Homeowner, Public INTEREST, Winter, 1971, at 106. 
$A$ for that loss. This rule for liability of landowners is overbroad and will be qualified. As a general rule, however, it is more in accord with the guidelines for efficiency than the laissez faire distribution of property rights discussed earlier.

When a physical change is intentional, as in the construction of a grocery, the party making the change will have better knowledge about possible external costs than outsiders affected by the change. The knowledge guideline thus suggests that the grocer should bear the loss. He is in a position to know that damage is almost certain and, by assuming the neighbors are of normal sensitivity, can estimate their prospective losses reasonably well. His victims, however, may be surprised when the loss occurs. In addition, a party intentionally making changes on his land is likely to be more expert than his neighbors about the particular type of harm involved and thus better able to evaluate potential preventive devices.

The second guideline, organization, also points to liability of the grocer. When one or more parties intentionally carry out an activity, they exhibit some degree of organization. In many land use cases the intentional actor acts alone and diminishes the property values of multiple neighbors who have no preexisting organization. One grocer can usually organize to deal with a risk of loss more cheaply than many homeowners.

The control guideline indicates only that liability should not be shifted to nonlandowners. It is impossible to determine, as a general rule, whether the most efficient preventive measures for reducing nuisance costs may be taken on the land where the damaging activity is occurring or on the injured properties. Neighbors of smoky factories can buy air conditioners, and Santa Monica Mountain homeowners can shutter their windows against grocery stores; on the other hand, it may be more efficient to install air-scrubbers or redesign the store. Information on the optimal prevention device must be available before the control guideline can be employed.

According to the fourth guideline, however, it is desirable to define a rule of general applicability for the allocation of rights. Since the first two guidelines point to assigning liability to the landowner making the intentional change and the third guideline is neutral, a general rule assigning liability to landowners who intentionally host physical changes that injure neighbors provides a good base for a system of nuisance law.

Changes in land use occasionally are accidental rather than intentional; these cases are harder to resolve. A landowner may try to paint his house white, but instead produce a repulsive shade of pink because 
an underlying coat of red paint unpredictably bleeds through. As changes become more accidental it is less likely that the owner of the property on which the change occurs is best assigned the risk. Since accidental losses are less predictable, the landowner may be poorly equipped to calculate the risk of loss accurately and thus be unable to assess intelligently the array of preventive measures available. A nonlandowner, such as the white paint manufacturer, might in fact be the cheapest cost avoider in the accidental pink house example. If the landowner intentionally painted the house pink, however, he should clearly be assigned the loss.

The law has also had much trouble deciding where to place the risk of loss for another class of damage-unintentional changes perceived as arising solely through natural forces. The law of torts generally requires some act as a prerequisite of liability. Nuisance cases absolve landowners from liability for damage caused solely by natural conditions on their property, such as stagnant water, spreading weeds, or ugly foliage. ${ }^{169}$ This reluctance to impose liability for inaction is often attributed to a concern for maintaining individual liberty by limiting the number of affirmative obligations. The act-omission distinction also makes considerable sense on efficiency grounds.

For intentional acts, the first guideline pointed to host landowner liability because he usually was best able to judge the magnitude of possible harm and assess available preventive measures. When a landowner does nothing to contribute to a damaging event, he may be as surprised as anyone when the damage occurs. The generalization about superior landowner information, however, is likely to be valid in two types of situations where he has been passive: where a landowner starts an activity and, by neglecting maintenance, fails to protect against its predictable natural deterioration; and where damage occurs in areas where land is so intensively used that landowners are normally aware of natural conditions on their property. In both these circumstances the risk of loss and the preventive measures available will generally be as apparent to the host landowner as to his neighbors or anyone else; modern nuisance doctrines impose liability in both situations. If a landowner starts an activity and then fails to finish it or fails to maintain the improvement in the normal way, he is liable for

169 See, e.g., Boarts v. Imperial Irr. District, 80 Cal. App. 2d 574, 182 P.2d 246 (1947) (refusing all relief where weeds had blown over from defendant's property); Merriam v. McConnell, 31 Ill. App. 2d 241, 175 N.E.2d 293 (1901) (refusing injunctive relief to plaintiff whose land was invaded by bugs from defendant's trees); RESTATEMENT OF TORTs $\S 840$ (1939); Restatement (Second) of Torts $\$ 840$ (Tent. Draft No. 16, 1970). 
failure to abate the harmful conditions created.170 Similarly, urban landowners are liable for failure to correct purely natural hazardous conditions. ${ }^{171}$ Use of urban parcels is usually sufficiently intensive for owners to be aware of such dangers.

Since this article focuses primarily on land use problems in urban areas, the general liability of a host landowner is proposed both for intentional changes and for damaging events on his property that arise through the workings of nature. In both situations the urban landowner is likely to be the most efficient bearer of liability.

2. Toward a Tripartite System of Internalization: The Unneighborliness Requirement. The general rule of host landowner liability for harmful externalities must be qualified in order to operate yet more efficiently. A landowner can reduce the welfare of his neighbors either by undertaking harmful activities or by terminating beneficial conditions that had previously existed on his property; the analysis thus far has dealt only with the former situation. A layman would regard a smokestack or a billboard as "theft" of neighborhood enjoyment that should be tagged with liability or proscribed. He would perceive quite differently, however, the demolition of an architectural landmark or the construction of a housing development on a beautiful vacant meadow. These latter acts would no doubt diminish neighboring property values, yet a layman would not characterize the acting landowner as a thief of neighborhood enjoyment, but perhaps as a former "Good Samaritan" who has understandably become tired of bestowing "windfalls" on his neighbors. Thieves, the layman would probably say, should be liable for the damage they cause, but lapsed Good Samaritans should not.

The wisdom of attaching any operational significance to this linguistic distinction has been a matter of considerable controversy. Some commentators have criticized the distinction on the ground that it cannot be determined which party is causing harm to the other. ${ }^{172}$ In

170 Restatement (Second) of Torts $\$ 839$ (Tent. Draft No. 16, 1970). Although the Restatement illustrates the duty to maintain artificial land improvements in a nonharmful state with a case involving cesspools, the same reasoning could be used to impose liability for failure to paint a house or clip an ornamental hedge. REsTATEMENT OF TORTs \& 839, Illustration 3 (1939).

171 The Restatement (SECOND) imposes an affirmative obligation on landowners in urban areas to correct harmful natural conditions, such as unstable native trees that threaten to topple over and injure people on the sidewalk or street. RESTATEMENT (SECOND) OF TORTS $\$ 840(2)$ (Tent. Draft No. 16, 1970). W. Prosser, TorTs, supra note 147, \& 57, at 355.

172 Coase, Social Cost, supra note 2, at 34-35. Compare Michelman, Property, supra note 21, at 1196-1201, with id. at 1235-45. But see Dunham, A Legal and Economic Basis for City Planning, 58 Colum. L. Rev. 650, 663-69 (1958). 
the Santa Monica Mountains case they would argue that one cannot determine whether the grocer is harming the homeowners with his commercial operations or, if the grocer must pay damages, the homeowners are harming the grocer through their sensitivities. In ordinary speech, however, people consistently distinguish "harms" from "benefits" and would agree that the grocery is doing the harming there. Evaluative terms like good, bad, beneficial, and harmful are easily used because people have remarkably consistent perceptions of normal conditions and thus can agree in characterizing deviations from normalcy. In any community, observers empirically establish standards of normal conduct for repetitive activities; people largely agree on normal clothes styles or normal behavior in public places. Similarly there is considerable agreement on the identification of normal land uses, a category virtually certain to include characteristics of modestly priced residential developments. ${ }^{173} \mathrm{~A}$ specific land use is characterized in ordinary speech as beneficial when it would have a more positive than usual impact, and harmful when it would have a more negative than usual impact, on the values of normal surrounding properties assuming a laissez faire distribution of property rights. ${ }^{174}$

Systems of compensating plaintiffs are also labeled according to the normalcy of the plaintiff's welfare after compensation has been provided. Generally, a plaintiff in a nuisance case is not "benefited" by being awarded judgment, he is simply "made whole." The defendant is not "harmed" by an adverse judgment, he is merely required to "make good the damage he has done." If liability rules required defendants to compensate plaintiffs for loss from the termination of the defendants' above-normal conduct, the rules would probably be viewed as unjust to defendants and bestowing windfalls on plaintiffs.

Normalcy has become a central concept in law ${ }^{175}$ as well as language, but the reasons for this importance have not yet been adequately explored. This article contends that normalcy is often used as a legal standard because the concept promises substantial efficiencies. In order to promote economically productive behavior that cannot be easily achieved by bargaining and to satisfy community desires to reward virtuous activities, legal rules should seek to transfer wealth from those whose actions have unusually harmful external impacts and to those

173 If streets are included, residential uses occupy the majority of the area of most cities. 174 The laissez faire model is probably incorporated in ordinary language because people recognize that administrative costs may impede legal correction of an immediate wealth transfer effect.

175 For a demonstration that perceptions of normalcy influence the legal language of causation, see H.L.A. Hart \& A. Honore, Causation in the LaW 31-38 (1959). 
whose actions are unusually beneficial to others. That pattern of transfers is now accomplished through a tripartite set of rules incorporating the normalcy standard: meritorious behavior is sometimes rewarded through quasi-contract doctrines and other devices, normal behavior is treated neutrally, and substandard behavior is penalized through liability rules and other sanctions. ${ }^{176}$

Distribution from the substandard and to the meritorious could also be achieved through a unitary approach that would not use the concept of normalcy. For example, a token liability to neighbors could be placed on the most meritorious conduct, with increasing penalties for less meritorious conduct; the standard of conduct toward others would thus be perfection rather than normal behavior. In this system a substandard landowner would suffer net losses since he would pay high penalties and recover lower ones from his normal neighbors. The most meritorious actors would pay small penalties and recover larger ones. The distributional result sought under the tripartite approach can thus also be achieved under a unitary approach. The legal system's adoption of the former must be attributed to a desire to save administrative expenditures. Normal actors in a tripartite system neither pay penalties nor receive rewards; if the range of normal conduct on the land use spectrum is broad, the administrative economies of that system are considerable. ${ }^{177}$

The notion of normalcy is implicit in much of the language of economics as well as law. It it probably no accident that economists use the term "goods" to describe output of producers for which consumers pay positive prices; the benefits that outsiders derive from that production are usually optimally internalized through prices paid in market exchanges. Economists have given less attention to the production of "bads," output that would attract bribes to stop, or negative prices,

176 This analysis demarcates rough boundaries of tort and contract law. The former is designed to deter below-normal behavior and the latter to provide incentives for abovenormal behavior. Tort texts often explore the use of liability rules to encourage unusually meritorious actions like the rescue of accident victims by bystanders. This article's analysis indicates that proper internalization in rescue situations will be most efficiently provided not through liability rules, but through quasi-contract doctrines, public prizes to Good Samaritans, or similar reward systems. For a discussion of the Carnegie Hero Fund, adopting this approach, see Wall Street Journal, October 13, 1972, at 1, col. 4. Cf. Epstein, $A$ Theory of Strict Liability, 2 J. Legal Studies, 151, 189-204 (1972); Franklin, Vermont Requires Rescue: A Comment, 25 Stan. L. Rev. 51 (1972).

177 The concept of normalcy provides administrative savings in areas other than law. For example, a language is a more efficient means of communication if no evaluative terms are needed to describe a broad band of normal conduct. The absence of both positive and negative adjectives implicitly communicates that the unmodified object is normal. Thus, the most common evaluation to be made is communicated by the cheapest means, silence. 
from consumers. Since economists are most comfortable with consensual market mechanisms, they may neglect the problem of bads because market mechanisms are usually less efficient than other means of internalizing bads.

The distinction in economic theory between harmful and beneficial spillovers reflects an underlying notion of normalcy. Modern scholars may be surprised that Pigou thought the proper way to handle air pollution was to give bounties to factories that cleaned up emissions, rather than to tax polluters. In an era when it was normal to pollute with coal-burning fireplaces, Pigou was probably right in recognizing that rewards were the most efficient internalization system and in perceiving the rare nonpolluter as a producer of beneficial externalities. Further, this example shows that the proper tagging of an externality should change as normal conditions change. Automobiles when they first appeared were nuisances to horse travel; as cars began to swamp horse-drawn vehicles in number, horses were properly perceived as the nuisance.

This article assumes that a tripartite legal approach to land use spillovers is more efficient than a unitary one. Proper internalization for the owner of a beautiful meadow or a beautiful building is then best accomplished through some reward system; his termination of those beneficial activities is deterred by concern about losing those rewards. ${ }^{178}$ Since the rules being formulated here are limited to the liability side of a tripartite system, imposition of host landowner liability must be limited to instances in which he undertakes subnormal activity. According to the simplicity of rules guideline, the addition of the element of subnormalcy to the prima facie case for nuisance will raise administrative costs in cases where the element is contested. Indeed, many students of tort law feel the added costs of the analogous fault requirement in negligence cases ${ }^{179}$ has undermined the viability of that system of liability, particularly in automobile accident cases. Fact finding in nuisance cases, however, is generally cheaper than in accident cases because the damaging condition is usually continuing; the administrative costs of a counterpart to the fault requirement should therefore be less.

The following modification in the general rule of host landowner liability is proposed to establish the tripartite system: a change in land

178 Evaluation of various reward schemes is beyond the scope of this article. See note 12 supra.

179 The fault system, relying as it does on the reasonable man standard, generally bars liability for normal conduct. Liability without fault has historically only been imposed on a small class of rare activities, such as those identified as ultrahazardous. 
use should result in liability of the host landowner only if the change is perceived as unneighborly according to contemporary community standards. In cases where only part of a complex land use is unneighborly, only the damage done by its unneighborly aspects should be compensable. For example, if a gas station blocks a scenic view, but a typical residence would also have blocked the view, damages from view blockage should not be included in the gas station's liability.

An unneighborliness test is a democratic and dynamic method of assuring that neighbors of an enterprising landowner do not receive excessive endowments of property rights. The unneighborliness concept is analogous to the emphasis on unreasonableness in current nuisance law, but the latter test is avoided here since it has been used in far too many situations to protect host landowners from liability, often by courts trying to avoid the harshness of injunctive relief.

Since the unneighborliness test is based on community standards, it requires some delineation of community boundaries. Using metropolitan areas as the relevant communities will involve lower administrative costs than a more decentralized definition. In addition, metropolitan areas are large enough to include all significant categories of a regional population; this characteristic tends to prevent nuisance law from being used to exclude groups or activities unpopular only in unusually sensitive neighborhoods of the metropolis. The metropolitan definition is also decentralized enough to take into account diversity from region to region. Mobile homes might be perceived as unneighborly land uses in Minneapolis but not in Duluth.

There is one major difference between the proposed unneighborliness requirement for nuisance liability and its "reasonable man" counterpart in negligence cases. The reasonableness of allegedly negligent conduct is tested under the circumstances in which it occurs. By analogy the neighborliness of gas stations throughout a metropolitan area should then be judged within less than metropolitan boundaries. Existing nuisance law rarely characterizes a land use as a "nuisance per se," assigning liability regardless of location; in most cases the challenged use must be a "nuisance in fact," unreasonable in its actual location. Although judicial acceptance of this approach is sensible when injunctive relief against nuisances is allowed, block-by-block assessment of neighborliness should be rejected if damages is the sole relief in nuisance cases. The purpose of the unneighborliness requirement is to eliminate normal and meritorious activities from the nuisance system to produce a savings in administrative costs; simplifying identification of the cases falling within the nuisance system makes its operation cheaper. Where damages is the remedy, imposition of a metropolitan 
standard will not result in inaccurate internalization of costs. For example, if a gas station is considered unneighborly in most locations, the proposed rule would impose liability even when it is surrounded by industrial properties, but the amount of damages assessed there would be less than usual because the industrial neighbors suffer less than normal losses.

Under the system described above an aggrieved landowner establishes a prima facie case for nuisance when he shows that his neighbor has damaged him by carrying on activities, or harboring natural conditions, perceived as unneighborly under contemporary community standards. To determine whether a prima facie case against a proposed grocery can be made out by homeowners in the Santa Monica Mountains, one would have to investigate perceptions of groceries as neighbors in Los Angeles County. ${ }^{180}$ Groceries are relatively rare land uses, and they must be perceived as unneighborly since they are barred, along with other commercial uses, by most restrictive covenants in modest residential areas in Los Angeles. A grocery should thus be treated as a nuisance in that region. This treatment can be accorded because groceries are not so common that imposing liability on them will result in inefficiently numerous claims, the danger inherent in imposing liability for normal land uses.

3. Compensable Damage: The Problem of Aesthetics. The formulation of the prima facie case discussed above allows recovery without a physical invasion of the damaged property, for example where the sole injury is to a landowner's psychological comfort or sense of aesthetics. This possibility represents a departure from prevailing legal doctrines reflected in decisions like Mathewson $v$. Primeau. ${ }^{181}$ The plaintiff in that case sought equitable relief from two conditions on defendant's property, hogs and an accumulation of junk. The court granted restrictions against the hogs since their odor occasionally travelled to the plaintiff's land. Relief was denied, however, against the pile of junk on the theory that it merely offended the plaintiff's aesthetic senses and thus could not be remedied through a nuisance action. This distinction is perhaps another of the distortions in nuisance law that has resulted from the limitation of remedies to injunctive relief. Since the severity of the aesthetic damage was probably slight, the court's refusal to enjoin the junk pile may well have avoided an in-

180 The sprawl of Southern California makes identifying the relevant metropolitan area more difficult than usual. Los Angeles County has been chosen because the Census Bureau recognizes it as a separate Standard Metropolitan Statistical Area.

18164 Wash. 2d 929, 395 P.2d 183 (1964). 
efficient remedy. There is no reason, however, why damages were not appropriate.

Although most courts accept the distinction made in Mathewson, some commentators have favored relief from aesthetic nuisances. ${ }^{182}$ In addition, a number of exceptions to the requirement of physical invasion have been recognized. Casting light on another's premises, arguably not an invasion, has routinely been held a nuisance. ${ }^{183}$ Relief has also been granted against spite fences, and other construction motivated by malice to neighbors and totally lacking in other utility. ${ }^{184}$ Another curious exception is the relief often provided against the operation of funeral parlors in residential areas, even where no invasion by fumes can be detected; many courts conclude that funeral homes inevitably remind people of death, cause consequent feelings of depression, and thus are sufficiently damaging to constitute a nuisance. ${ }^{185}$

Extensive exceptions to limit a legal rule often betray the conceptual frailty of the rule itself. Although physical invasions are almost always perceived as unneighborly and thus provide a good case for relief, the physical invasion test does not exhaustively identify the occasions for imposing nuisance liability. ${ }^{186}$ When an unneighborly land use decreases surrounding property values, the traditional objections to recovery in the absence of physical invasion are not persuasive. Damage from aesthetic blight may be difficult to measure, but so may damage

182 See, e.g., Noel, Unaesthetic Sights as Nuisances, 25 Cornell L.Q. 1 (1939); Note, Aesthetic Nuisances: An Emerging Cause of Action, 45 N.Y.U.L. REv. 1075 (1970).

183 See Annot., 5 A.L.R.2d 705 (1949). Blocking natural light sources, however, generally does not give rise to liability in this country. See, e.g., Venuto v. Owens-Corning Fiberglas Corp., 22 Cal. App. 3d 116, 127, 99 Cal. Rptr. 350, 357 (1971). The distinction may be based on the difficulties raised by the English doctrine of "ancient lights" that provided injunctive relief to protect natural light sources. For a glimpse of the problems with this doctrine, see Colls v. Home and Colonial Stores, [1904] 73 Ch. 484 (reversing the granting of an injunction against further construction of an addition to a building that would have slightly darkened the plaintiff's ground level offices).

184 See, e.g., Burke v. Smith, 69 Mich. 380, 37 N.W. 838 (1888); Welsh v. Todd, 260 N.C. 527, 133 S.E.2d 171 (1963); Annot., 133 A.L.R. 691 (1941).

185 See, e.g., Brown v. Arbuckle, 88 Cal. App. 2d 258, 198 P.2d 550 (1948); Jack v. Torrant, 136 Conn. 414, 71 A.2d 705 (1950); Rockenbach v. Apostle, 330 Mich. 338, 47 N.W.2d 636 (1951); Rutledge v. National Funeral Home, 203 So. 2d 318 (Miss. 1967). But see, e.g., Dean v. Powell Undertaking Co., 55 Cal. App. 545, 203 P. 1015 (1921); Pearson \& Son v. Bonnie, 209 Ky. 307, 272 S.W. 375 (1925); Westcott v. Middleton, 43 N.J. Eq. 478, 11 A. 490 (1887), aff'd, 44 N.J. Eq. 297, 18 A. 80 (1888). See also sources cited note 153 supra; Comment, Funeral Homes: Their Locations in the Community as Controlled by Zoning Ordinances, Restrictive Covenants, and the Law of Nuisance, 20 SYRACUSE L. REv. 45 (1968).

186 Michelman makes a similar observation about the use of a physical invasion standard to identify compensable "takings" by government. Michelman, Property, supra note 21 , at $1227-29$. 
from noise, smoke, vibration, or other spillovers readily accepted as nuisances. Nor does there seem to be any physiological or psychological reason to distinguish visual harm from other types of sensory discomfort. ${ }^{187}$ Idiosyncratic tastes of the complaining landowner are not more likely to arise in aesthetic cases than in olfactory cases and can be eliminated by measuring damages according to market values ${ }^{188}$ and recognizing a defense of hypersensitivity. ${ }^{189}$ Finally, concern for preservation of individual freedom and self-expression of landowners does not justify refusal to recognize aesthetic nuisances. Playing a musical instrument may be as important to one individual as building in an odd architectural style is to another, yet noise is widely recognized as a nuisance. The category of aesthetics does not precisely delimit the instances for paramount concern for the protection of individual liberty. ${ }^{190}$ The bar against recovery for aesthetic nuisance should be eliminated from the law, and the suggested prima facie case succeeds in eliminating it.

4. Measuring Damage: Bonuses for Consumer Surplus. Where compensation is to be allowed, a system must be designed to measure its proper amount. The golden mean of normalcy would seem to be achieved by requiring the defendant to pay to the plaintiff an amount equal to the drop in the market value of the plaintiff's property that would be caused by the defendant's unneighborly use if there were no right to recovery. If periodic rather than permanent damages were awarded, they would equal the lost rents over the relevant period discounted to present value. The market value of a plaintiff's land would then not vary with changes in expectations about nearby nuisances; the land value would drop only if the plaintiff cashed in on his future rights to damages. This compensation measurement would thus seem to protect the normalcy of the plaintiff's welfare.

Use of market values for measuring damages in nuisance cases, however, may be inappropriate. There is a minimum price at which any person would voluntarily exchange any item of his property. The excess of this subjective value over market value is termed "consumer surplus." ${ }^{191}$ Consumer surplus creates no problems in the law of

187 Although there is less physical effort involved in averting one's eyes than in holding one's nose or muffling one's ears, the opportunity costs of restrictions on sight are apt to be greater than the opportunity costs of restrictions on smelling or hearing.

188 See text at notes 191-96 infra.

189 See text at notes 241-55 infra.

190 See text at notes 231-37 infra.

191 This term is being used to include differences between subjective valuations and market prices that arise after the purchase of an item; economists seem to use the term more narrowly. 
damages when property is fungible; the owner can recover lost surplus by repurchasing the lost item at market prices. If the lost property is not fungible, however, a potential replacement item cannot provide as large a surplus as its predecessor. For example, a longtime owner of a single-family home in a stable residential area might not willingly part with his dwelling except at a substantial premium over the market price. His surplus would be based in part on experience in using this particular house and sentimental memories connected to it. Using market values to measure damages to this homeowner from a nuisance seems unfair because the homeowner is apparently not made whole, and inefficient since the external costs involved seem to be incorrectly calculated. ${ }^{192}$

Market values represent a community consensus on the severity of the harm inflicted, ${ }^{193}$ however, and may in fact not be an unfair or inefficient standard. If a person feels that the market undervalues his damage, he may be unusually sensitive and the best cost avoider of the losses resulting from that hypersensitivity. ${ }^{194}$ The imprecision of market values may also be tolerable because of the resulting savings in administrative costs. Reliable calculation of consumer surplus is inherently expensive because of difficulty in screening out fraudulent claims.

Nevertheless, there are types of nonfungible property to which most owners attach considerable consumer surplus. Possessions such as long-occupied single-family homes in stable residential areas tend to attract increasing subjective valuations as the tenure of ownership increases. The property owner with a common nonfungible surplus is normally sensitive, not hypersensitive, and consequently not likely to be the best avoider of losses of that surplus. A desirable system for dealing with this problem is to award damages for the drop in market value plus a bonus award to compensate for loss of the commonly held irreplaceable consumer surplus. To limit administrative costs such bonuses could be defined through legislated schedules, perhaps as specific percentages of the market value award. Different percentages based on factors such as the longevity of occupancy of the injured neighbor, or

192 The shortcomings of using market values to measure losses also highlight one of the advantages of consensual solutions to problems of external cost. Bargaining permits subjective, idiosyncratic assessments of value; collective valuation systems, explicitly needed in nuisance law, and implicitly required by regulatory systems like zoning, must proceed on more impersonal, objective lines.

193 See Michelman, Toward a Practical Standard of Aesthetic Regulation, 15 Prac. LAw., No. 2, 1969, at 36, 37, 42.

194 Cf. G. Calabresi, Cost of Accidents, supra note 11, at 222-24. See also text at notes 241-55 infra. 
whether the neighbor is an owner-occupant or a renter, would be justified if uneven patterns of subjective value could be verified empirically. ${ }^{195}$ Resort to schedules assumes that individualized valuation is not cost-justified. ${ }^{196}$

5. The Requirement of Substantial Harm. Prevailing nuisance law requires that the plaintiff suffer "substantial harm" to be entitled to relief. ${ }^{197}$ This condition is essential to an efficient prima facie case. If plaintiffs are allowed to bring suits for trivial damages, the administrative costs involved are likely to exceed the efficiency gains of permitting such suits. ${ }^{198} \mathrm{~A}$ rational plaintiff will pursue all claims where his expected costs of pursuing the claim are less than his expected benefits from success discounted by his perceived probability of success. ${ }^{199}$ The plaintiff, however, will not consider the administrative costs his actions impose upon either the defendant or the dispute-resolution system. ${ }^{200}$ The total administrative cost of a rational but trivial claim may thus exceed the reduction in the sum of nuisance and prevention costs achieved by granting the claim. A requirement of substantial harm as an element of the prima facie case thus promotes efficiency by eliminating inefficient cases that survive the unneighborliness requirement.

That an individual case is inefficient under the substantial harm requirement, however, should not create an absolute requirement of its dismissal. The substantial harm requirement should not bar a claim where it can be ascertained that short-term efficiency losses involved in granting relief are less than the efficiency gains of establishing prece-

195 Bonus payments disguised as relocation payments are now granted to condemnces displaced as a result of federal or federally assisted programs. The Uniform Relocation Assistance and Real Property Acquisitions Policies Act of 1970, 42 U.S.C. $\S \S 4601-4655$ (Supp. 1973), provides for awards of up to $\$ 15,000$ over fair market value to homeowners, $i d$. $\S 4623$, and up to $\$ 4,000$ to tenants, id. $\S 4624$. A HUD survey found actual awards averaging nearly $\$ 10,000$ per homeowner and $\$ 2,870$ per tenant. Abramowitz, Uniform Relocation Act Defended, 29 J. of Housing, 279, 280 (1972). The average payment to homeowners displaced by Federal Highway Administration programs in 1971, however, was a less generous $\$ 2,800$. Note, In the Path of Progress: Federal Highway Relocation Assurances, 82 YALE L.J. 373, 379 n.38 (1972).

196 See note 275 infra.

197 W. Prosser, Torts, supra note $147, \S 87$, at 577-78; Restatement (Second) of Torts § 821 F (Tent. Draft No. 16, 1970).

198 Cf. Calabresi, Some Thoughts on Risk Distribution and the Law of Torts, supra note 11 , at 537 .

199 See Posner, An Economic Approach to Legal Procedure and Judicial Administration, 2 J. Legai Studies 399 (1973). In calculating expected benefits and costs the plaintiff will take into account the possibility of settlement or judgment and also the effect of his action on his credibility to others in similar future suits.

200 Such costs might include the defendant's costs, plaintiff's costs assignable to the defendant, or costs of the adjudication machinery not covered by user fees. 
dents that will cause similar harm-inflicters to undertake efficient preventive measures or settle quickly with those they injure. For example, singly inefficient damage suits against slightly offensive gas stations may enhance overall efficiency if their success prompts oil companies to design their future outlets more carefully.

Application of the substantial harm requirement is particularly difficult when a large plaintiff class alleges harm and seeks damages. Total costs of organizing, making strategy, and sharing costs and awards rise with the number of plaintiffs, but economies of scale may be present. Further, as the nuisance becomes more pervasive, the total damage increases and large efficiency gains are more likely to result from the adoption of preventive measures. In these suits the substantial harm test should first be applied to each member of the plaintiff class to eliminate members whose damages are less than the marginal administrative costs their claim imposes on the class. The threshold level of damages required of each of the eligible plaintiffs may be less than that required of a lone plaintiff because of possible efficiencies involved in multiple-plaintiff claims. The requirement of substantial harm, however, will narrow the eligibility for damages from a pervasive nuisance to the few, if any, parties suffering relatively acute injury.

6. Remedies: The Plaintiff's Choice between Damages and Purchasing an Injunction. In a recent and stimulating article Calabresi and Melamed observed that there are four possible rules on remedies in nuisance cases. ${ }^{201}$ Under the first rule the plaintiff is entitled to enjoin the defendant's nuisance. Second, the plaintiff is entitled to damages from the defendant but not to injunctive relief. The third rule is that the plaintiff may neither enjoin the defendant's conduct nor collect damages. The fourth rule, generally ignored by legal commentators, permits the plaintiff to enjoin the defendant's conduct, but only if he compensates the defendant for the defendant's losses caused by the injunction. ${ }^{202}$ When a nuisance exists, present principles always allow the plaintiff to invoke rule two (damages) and in a great many situations to invoke rule one (injunction).

Nuisance law would function better if, in general, a plaintiff in a nuisance case were limited to choosing between the remedies of rule two (damages) and rule four (compensated injunction). Adoption of this recommendation would obviously constitute a major reformation

201 Calabresi \& Melamed, supra note 11, at 1115-23.

202 The fourth remedy will be referred to as a "compensated injunction" to distinguish it from the first remedy, termed simply an injunction or injunctive relief. 
of prevailing nuisance doctrine. ${ }^{203}$ The following discussion examines the usual justification for injunctions in nuisance cases and demonstrates the advantages of the second and fourth rules. Rules one and three are recognized as appropriate, however, in certain unusual nuisance situations where they are essential to protect the fundamental rights of one of the parties.

The major danger of injunctive relief is that the cost to the defendant of an injunction might exceed its benefits to the plaintiff, and that, because of high administrative costs, the parties will be unable to bargain for a modification of the overly strict decree. Courts generally recognize this danger and try to balance the utility of the defendant's activity against the amount of damage it does, before granting injunctive relief. These balancing exercises are expensive and introduce considerable uncertainty into the conflict resolution process. The courts are often forced into this balancing chore in nuisance litigation because there is nothing to deter a plaintiff from seeking an inefficient injunction.

Rule two and rule four, however, are less likely to be inefficient remedies. Rule two internalizes the nuisance and permits the defendant to make his own cost-benefit analysis of preventive measures. By shifting the costs of an injunction back to the plaintiff, rule four discourages plaintiffs from seeking inefficient injunctive restraints, and thus saves some of the administrative costs of rule one. Although rule one injunctions may be warranted in certain situations, the usual justifications for injunctions are unpersuasive; this article proposes that the courts adopt a rebuttable presumption against the availability of that relief in nuisance cases.

a. Commentators have traditionally offered four primary rationales for injunctions. ${ }^{204}$ First, since market values do not reflect the subjective losses a plaintiff suffers and since those losses are hard to monetize by any other means, the remedy of damages is said to be inadequate..$^{205}$ As has been pointed out, however, this shortcoming of the damage remedy can be overcome for common subjective values through bonus

203 This change actually increases the remedies avaliable to plaintiffs. If the external costs of an activity exceed its internal benefits to the defendant, the balancing test currently entitles the plaintiff to an injunction. Rule four would continue to entitle him to a "free" injunction in this situation. See note 222 infra. Where the balancing test operates in favor of the defendant, the plaintiff is currently denied an injunction and often damages as well. Rule four and rule two, however, provide him remedies when balancing works against him.

204 See Developments in the Law: Injunctions, 78 HARv. L. REv. 994, 1002-04 (1965).

205 See, e.g., G. Calabresi, Cost of Accidents, supra note 11, at 97-100, 203-04. 
payments calculated from legislated schedules. ${ }^{206}$ If he holds unusual subjective values, the landowner is hypersensitive ${ }^{20 \tau}$ and, except in cases involving personal safety or fundamental freedoms, has no persuasive claim to injunctive relief.

b. A second justification for rule one is the moral assertion that a landowner should not be able in effect to exercise a private power of eminent domain and force others to exchange basic property rights for damages. ${ }^{208}$ By adopting rule two, however, our legal system has long tolerated such forced exchanges where they would promote efficient land use. For example, a landowner's remedy against a trespasser is limited to damages if the trespass was justified by some incomplete privilege like private necessity. If the invader can meet the requirements for an easement by necessity, rule three is applied, and the servient landowner is not even compensated for the exchange.

Forced exchanges, or nonconsensual interferences with an individual's living arrangements, are most disturbing when they threaten fundamental liberties. Murderers and slave-traders obviously should be enjoined even if they could somehow compensate their victims. Similarly, if one function of property is to provide a shield behind which an individual can nurture his eccentricities, in some situations he should be entitled to stop disturbances of his domain without making a rule four payment. If courts rarely grant injunctions against nuisances, however, society may benefit from increased landowner choice among affirmative activities within their own boundaries. The problem is to identify the disturbances so threatening to individual liberty that they justify use of injunctive relief. A trade-off must be made between the value of individual autonomy and the possible efficiency and liberty gains from fewer restrictions on interactions.

To accommodate these conflicting goals, the proposed presumption against injunctive relief in a nuisance case should be open to being rebutted by a showing that the plaintiff's personal safety or fundamental freedom of action within his boundaries has been or will be critically curtailed by the defendant's activity. The plaintiff will then generally be entitled to enjoin encroachments that oust him from part of his property. ${ }^{209}$ Rule one injunctions should in addition be available against

206 See text at notes 191-96 supra.

207 See text at notes 241-55 infra.

208 See, e.g., G. Calabresi, Cost of Accidents, supra note 11, at 100-02; Calabresi, Some Thoughts on Risk Distribution and the Law of Torts, supra note 11, at 536; cf. Ross, Book Review, 84 Harv. L. Rev. 1322, 1323-24 (1971).

209 This principle is not without exception. For example, if a downstream landowner dams a watercourse and floods the lands of his upstream neighbor, Mill Acts in many 
invading fumes or other substances likely to kill or critically injure normally sensitive people. Unprivileged continuing trespasses by people should also be subject to injunctive relief; those invasions of privacy are likely to restrict the landowner's choice of lifestyles. ${ }^{210}$ The proposed rule for identifying situations appropriate for injunctions is admittedly vague, and ambiguous cases are certain to arise. The majority of nuisance activities, however, involve only what might be termed inconveniences; injunctions are rarely essential for libertarian reasons and should usually be withheld because of the disadvantages of injunctive relief.211 For example, the external costs of spite fences, as outrageous an activity as one is likely to find in a nuisance case, can be best internalized by allowing the plaintiff to choose between rule two and rule four relief. ${ }^{212}$

c. The third rationale used for injunctions is that damages are inadequate when the defendant is judgment-proof. This argument is self-limiting; it holds only if the plaintiff can show that he could not collect a monetary award. In addition, this justification is not convincing in a nuisance case even when the defendant is destitute. A lien based on a judgment or a settlement arising from misuse of a property could be given priority over all mortgages on that property; this treatment would induce mortgagees to discourage a mortgagor's inefficient nuisance activities. ${ }^{213}$ Even if this priority rule were not adopted, a plaintiff in a nuisance case need not worry about judgment-proof defendants as much as plaintiffs in other cases. By definition landowners have assets on which a plaintiff could levy to receive cash, or at least the termination of the defendant's ownership. Short-term tenants responsible for nuisances, however, may not possess a lienable interest. This threat to the adequacy of the damage remedy could be eliminated

states adopt rule two and limit the upstream owner to damages. Constitutional attacks on these acts have been unavailing. Head v. Amoskeag Mfg. Co., 113 U.S. 9 (1885). See generally Note, The Public Use Limitation on Eminent Domain: An Advance Requiem, 58 YaLe L.J. 599, 604-05 (1949).

210 Occasional trespass by nonvicious animals, however, would neither threaten personal injury nor chill any of the landowner's activities. Thus, it should not be enjoined.

211 John Rawls has proposed a set of "basic liberties" that would prevail in a just society; he would forbid even consensual exchanges of these liberties for social and economic benefits. J. RAwLs, supra note 30, at 60-61, 243-48, 541-48. He would not count freedom from unpleasant neighboring conditions as a basic liberty.

212 The price for purchasing a rule four injunction against a spite fence will usually be zero because these structures by definition have no positive market value. The price will be greater than zero only if the cost of removing the fence exceeds the damages it does. See note 222 infra.

213 This priority rule assumes that the allocative gains from such private policing exceed the added administrative costs of the rule. 
by holding a landlord liable for the nuisances of his short-term tenants and granting him the right of indemnification against the tenants.

d. A fourth justification for rule one injunctions is that administrative factors can make granting an injunction more efficient than awarding damages. The merits of each of the four rules on remedies vary according to the number of parties involved in a land use controversy. Where many plaintiffs are harmed by a single defendant's activity, rule one injunctions are likely to have major allocative costs. If a court imposes preventive measures that are too harsh under a costbenefit analysis, the defendant will have great difficulty negotiating removal of the injunction. He must obtain a release from every member of the plaintiff class since each can enforce the injunction, and each plaintiff would wait to be the last to release his rights since his bargaining power increases as others sell their releases. Aware of this holdout problem, the defendant may not care to begin to negotiate the release of the strict decree. Thus, the judiciary should be cautious when considering equitable relief in pervasive nuisance cases since the market cannot be relied upon to correct the inefficient aspects of the injunction. ${ }^{214}$

The second and fourth rules involving payments may be even less desirable in these cases. Although damage actions and compensated injunctions are less likely than imprecise injunctions to cause major uncorrected misallocations, they may be less efficient if their allocative advantage is outweighed by added administrative costs; increased costs could result from the need to calculate and distribute damage awards to or collect purchase contributions from a large plaintiff class. Rule three also seems unattractive since it leaves the harmful externalities uninternalized. Among the four rules, rule one may be the most efficient for pervasive nuisance cases. Nevertheless, Calabresi and Melamed are right to be chary of injunctions against widespread environmental nuisances. All four rules are apt to be inferior in these cases to options outside the arena of private civil litigation, notably publicly assessed fines and mandatory legislative regulations. ${ }^{215}$ Most commentators

214 See Calabresi \& Melamed, supra note 11, at 1106-07, 1119.

215 See text at notes 269-318 infra. The preferability of legislative regulations to judicial injunctions is not obvious. If mandatory regulations are appropriate for handling certain pervasive nuisances, it is not clear why a court cannot frame such regulations via injunctions as well as or better than a legislative body. In some situations ad hoc judicial injunctions might involve lower administrative costs than legislative enactment and enforcement of mandatory standards and prohibitions. In addition, legislatures are prone to enact particularly inefficient regulations when some of the costs of those regulations are borne by those outside that legislative process. The legislative process is also likely to be inefficient in resolving conflicts between two interest groups when those groups face vastly different costs of organizing for political action.

Nevertheless, except when these legislative shortcomings are overwhelming, the legisla- 
thus agree that rule one is rarely the optimal remedy for pervasive nuisances.

The relative efficiency of injunctions and damages in more localized nuisance cases raises different considerations because of the lower administrative costs involved in dispute resolution. Calabresi and Melamed assert that injunctive relief may be more efficient when administrative costs are sufficiently small; they analyze a hypothetical conflict between two individuals, Marshall and Taney, to support their proposition. ${ }^{216}$ They suggest that if Marshall is entitled to a rule one injunction that directs Taney to take inefficient preventive actions, Taney will not be deterred by the possibility of high transaction costs from bargaining for at least a partial release of the strict decree. Calabresi and Melamed imply that the allocative crudeness of injunctions is thus readily corrected by the market in one-on-one cases and that rule one is preferable to rule two in such cases because it avoids two costs of damage actions: the administrative costs of judicially or legislatively valuing damages and the costs of coercing plaintiffs who are forced to exchange their rights at prices to which they might not voluntarily consent. ${ }^{217}$ The concern about coercion is curious since the problem is reciprocal; plaintiffs are coerced by forced exchanges, but defendants are coerced by injunctions. There is no apparent reason why either form of coercion should be more costly than the other. The observation about administrative costs has considerable surface appeal since collective rules on damages are expensive to administer. On further analysis, however, it appears that Calabresi and Melamed failed to note that a combination of rule two and rule four may involve lower

ture is likely to be a less dangerous branch of government than the judiciary from an efficiency standpoint. Legislatures are institutionally urged toward favorable cost-benefit decisions, while courts are more insulated from such pressure. If some legislative action, or inaction, is clearly inefficient, there are crude pressures working within the political process to eliminate the inefficiency. For example, overly strict preventive measures will be strongly opposed by the regulated group, but weakly defended by the intended beneficiaries of the regulation since they gain only a small reduction in nuisance costs from the measures. There are basic similarities between the legislative and bargaining processes. In the legislative process, participants try to purchase collective bargains, or laws, with the currency of politics-votes, campaign contributions, volunteer work, and bribes. Although it is less reliable than private bargaining, the legislative process does have an institutional tendency to move in the same direction as bargaining, toward minimizing the sum of nuisance and prevention costs. Assuming it is not corrupt, the judicial system contains less effective checks against inefficiency. Land developers aggrieved by overly strict zoning may be able to vote out, or buy out, the offending zoning officials, but they are comparatively helpless in the face of an overly strict injunctive decree. Thus, in the few instances where the establishment of mandatory standards and prohibitions is appropriate, those standards should be established by the most politically sensitive government institution.

216 See Calabresi \& Melamed, supra note 11, at 1118.

217 Id. at 1118-19. 
administrative costs than rule one in the settlement process of even one-on-one controversies. This team of remedies can accomplish at least three types of administrative savings.

First, the "valuation costs" incurred by the parties before they agree on a price for settlement are likely to be higher in a case where the plaintiff is entitled to injunctive relief than where the plaintiff must choose between damages and a compensated injunction. ${ }^{218} \mathrm{~A}$ party involved in negotiations over the release of an injunction would become involved in the search for clues to the subjective values held by his adversary. For instance, a plaintiff entitled to an injunction would seek to determine the defendant's subjective valuation of his nuisance project since that value represents the plaintiff's ideal settlement figure. Conversely, the defendant would try to discover his own ideal settlement figure by seeking the plaintiff's subjective valuation of the plaintiff's losses from the project. This search process would involve strategems such as exploratory offers, false signals, and threats; these same tactics are also used in settlement negotiations over damage claims. The critical difference between rules one and three and rules two and four is that under rules one and three the parties have no collective valuation rules to refer to when estimating an appropriate settlement figure. If a plaintiff were restricted, however, to a choice between collecting damages and purchasing an injunction, collective rules on damages would establish targets for appropriate settlements and would considerably narrow the range of disagreements to be negotiated. If the collective rules were comprehensible, the parties could calculate the damages the plaintiff would collect in litigation from the defendant and the price the plaintiff would have to pay for an injunction. A hypothesis of this article is that valuation costs, and thus administrative costs, tend to be higher when there are no such external guidelines to constrain the settlement figure under negotiation. Calabresi and Melamed have noted the difficulty of ascertaining subjective values ${ }^{219}$ and show evidence at times that they would agree with this hypothesis. ${ }^{220}$

Rule four remedies, although historically not available in nuisance cases, may thus be an efficient addition to the array of remedies available to the plaintiff. Granting the plaintiff the option of purchasing an injunction should expedite the private settlement of cases where the plaintiff perceives rule two damages as inadequate. A recent case, Spur

218 If the collective rules for measuring damages are vague, this advantage may of course be lost.

219 Id. at 1095 n.13, 1109 n.38.

220 " $[\mathbf{W}]$ here negotiations after an accident do occur-for instance pretrial settlements -it is largely because the alternative is the collective valuation of damages." Id. at 1109. 
Industries, Inc. v. Del E. Webb Development Co., ${ }^{221}$ involved such a situation, and the court in fact imposed a rule four remedy. Spur Industries operated a cattle feedlot outside Phoenix, Arizona, that held 30,000 cattle in peak seasons. A herd that size produces over a million pounds of wet manure a day, attracting flies and emitting annoying odors. After the feedlot had been established, the plaintiff began development nearby of a major retirement community called Sun City and sought to enjoin the operation of the feedlot. The Supreme Court of Arizona granted the injunction, but conditioned this remedy on the plaintiff paying the defendant its costs "of moving or shutting down" because Sun City had come to the nuisance. ${ }^{222}$

Availability of a compensated injunction probably reduces the valuation costs involved in voluntary settlement of a controversy like Spur Industries. If the developer invoked the rule two remedy, he should not be entitled to his full damages, because, as suggested below, ${ }^{223}$ he indeed came to the nuisance. Thus, even if the feedlot is inefficiently located, a damage award would not necessarily result in its closing since that award would be less than the full burden of the feedlot on Sun City. If the development company were limited to a rule two recovery, it might therefore try to negotiate with Spur for termination of the feedlot. The cost of these negotiations would likely be lower if the developer were entitled to purchase an injunction; collective rules would set a target for settlement, and the defendant would realize that the plaintiff could ultimately force an injunction on him at that price. ${ }^{224}$

The main role of rule four is to facilitate the termination of a nuisance whose harm a plaintiff subjectively values at an amount greater than the damages he can recover under rule two. ${ }^{225}$ This situation is

221108 Ariz. 178, 494 P.2d 700 (1972).

222 The measure of damages under rule four should be the diminution, if any, in the market value of defendant's land, structures, and equipment resulting from his future inability to devote his property to the enjoined nuisance activity. This formula automatically takes into account the lesser of the defendant's relocation and shutdown costs. The defendant's compensation for a rule four injunction is zero unless the internal benefits to him of the nuisance exceed its total external costs, as those costs are valued collectively. If his neighbors' losses exceed his benefits, the curtailment of his nuisance activity would raise his property values by reducing his liabilities.

223 See text at notes 256-68 infra.

224 Rule four remedies are less likely to be useful where there are multiple plaintiffs and thus freeloader problems.

225 Where the plaintiff obtains a preliminary injunction, and the defendant's use is at least temporarily discontinued, both parties have an incentive to obtain a private settlement that would provide a rapid final solution and avoid the expense of litigation. Even where the plaintiff does not obtain a preliminary injunction, the rule four injunction remedy provides a target for settlement, indicating the maximum the defendant can demand from the plaintiff for termination, and thus will facilitate private settlement. 
most common when the plaintiff has unusual subjective values, his activities are hypersensitive to injury, or he has come to the nuisance. Availability of compensated injunctions is also useful in assuring the immediate termination of nuisances where collective valuation systems indicate that the activity generates greater external costs than internal benefits, but the defendant's subjective values lead him to conclude otherwise and thus a judgment for damages would not shut him down. In that situation the defendant is not entitled to compensation under rule four; an appropriate restriction on his activities would, if anything, increase the value of his land by reducing his nuisance liabilities. Rule four thus gives priority to the subjective values of normal landowners over the perverse subjective benefit a defendant receives from his nuisance activity, the preferred result from a distributional standpoint. ${ }^{226}$

A second advantage of the combination of the rule two and rule four remedies that Calabresi and Melamed may have overlooked is that under those rules nuisance activities that are prospectively worthwhile will be subject to less delay in starting than if they are vulnerable to rule one injunctions. If rule one is available in a one-on-one situation, a landowner planning some nuisance activity will usually delay its start until he settles with the sole plaintiff who could enjoin it. Starting earlier would greatly weaken his bargaining strength by enabling the plaintiff to hold him up at critical junctures. The defendant might of course try to force a quick settlement by threatening to abandon his plans or move the activity to another location. Even if the defendant made those threats, however, the plaintiff would still be

226 Allowing successful plaintiffs to choose between damages and a compensated injunction raises some procedural questions. Upon making the proper showing, a plaintiff invoking rule four should be entitled to secure a preliminary injunction against further expansion of the defendant's activity to minimize the required payment to the defendant. A preliminary injunction, however, is obviously harsh on the defendant. Consequently, if a plaintiff obtains an injunction under rule four, he should not be permitted to abandon that route; otherwise he could use the preliminary injunction as a tactical maneuver in bargaining. The tribunal issuing the preliminary injunction must also assure the defendant adequate security for the payment the plaintiff will owe him. The plaintiff should thus be required to post an adequate bond.

Plaintiffs lacking security for rule four payments are a more serious concern than defendants lacking security for rule two payments. Nuisance cases commonly involve multiple plaintiffs, but rarely multiple defendants. Multiple plaintiffs might conspire to have one member of the class bring an action that would bankrupt him individually, after which the entire plaintiff class would secretly chip in for his support. These same plaintiffs might have spurned the rule four remedy if required to compensate the defendant fully. In contrast, when the defendant's security for rule two payments is inadequate, the plaintiffs will be able to foreclose their judgment lien and terminate his ownership of the offending property. 
likely to take time before settling to gather clues about the defendant's relocation costs and the defendant's subjective valuation of his proposed activity. In any case, the defendant will be strongly inclined to delay his project until a settlement has been drafted, signed, and possibly recorded in public records to bind the plaintiff's successors in ownership. If the plaintiff's choice is between damages and a compensated injunction, however, the defendant will have little reason to delay his activity once he has estimated the collective assessments of the appropriate awards under each rule. To the extent that the collective rules are clear, delay will be slight; the defendant's strategic reason for delaying activity, fear of loss of bargaining power, evaporates when uncompensated injunctive relief is no longer available. ${ }^{227}$

Finally, the availability of injunctive relief in localized nuisance cases would complicate legal rules on remedies. If injunctions are denied in pervasive nuisance cases because they threaten uncorrectable misallocations of resources, yet are available in localized cases due to reduced administrative costs of bargained corrections, the legal system will be required to develop rules for estimating the level of administrative costs in each dispute. ${ }^{228}$ Those rules themselves would create, however, considerable administrative costs since uncertainty about entitlements to rule one remedies would seriously complicate settlement negotiations. ${ }^{229}$

Administrative cost questions are ultimately empirical, and it may be that the remedy used in one-on-one situations does not significantly affect efficiency. The conclusion apparently reached by Calabresi and Melamed, that rule one remedies are preferable in one-on-one nuisance cases, is not clearly wrong; this article suggests, however, that injunctions may create at least three administrative problems in that simplest of settings: the cost of difficult searches for subjective values, delays in initiation of cost-justified nuisance activities, and added administrative costs in determining what remedies are available in a specific case.

In sum, the justifications generally offered for rule one injunctions are

227 There may be an advantage to the entire system in encouraging the defendant to start early. Disputes over an executed settlement agreement are less likely when the agreement is made after the defendant begins his nuisance activity. A plaintiff can attack a preactivity settlement on the ground that the defendant misrepresented the nature of his prospective activity.

228 A rule that uncompensated injunctions are available only in one-on-one situations would not eliminate any ambiguities, but merely shift the defendant's attention to the legal rules governing the standing of plaintiffs.

229 To estimate the magnitude of this problem, one might investigate the extent to which the doctrines now limiting rule one relief, such as laches, unclean hands, estoppel, and balancing of hardships, create uncertainties that impede private settlement negotiations. 
certainly not compelling in most instances; the plaintiff normally should be forced to choose between collecting damages and purchasing an injunction. ${ }^{230} \mathrm{~A}$ rebuttable presumption against rule one injunctions should exist in nuisance cases, and be overcome only when the plaintiff can show that his personal safety or fundamental freedoms are vitally threatened by the defendant's activity. Rule one relief is justified to protect essential liberties, but few modern urban nuisances threaten invasions of that type.

The prima facie nuisance case can now be summarized as follows:

A landowner who intentionally carries out activities, or permits natural conditions to develop, that are perceived as unneighborly under contemporary community standards shall be liable for all damages (measured by the diminution in the market value of plaintiff's land plus bonuses for diminutions in widely held subjective values) to all parties who are thereby substantially injured, and continuation of the activity may be enjoined by any party willing to compensate the landowner for any losses he suffers from that injunction.

\section{Nuisance Law: Defenses}

Plaintiffs who succeed in making out a prima facie case in nuisance should not be entitled to remedies that would violate the defendant's fundamental liberties or conflict with the four guidelines for the effcient assignment of rights. Affirmative defenses involve additional administrative costs. Nonetheless, four defenses to the prima facie case are now proposed: the first two to protect the defendant's liberty and the last two to promote efficiency. These defenses will often be incomplete, and in such cases the parties in conflict will ultimately be required to split the contested cost between them.

1. The Defense of Freedom of Expression. This article has already suggested that a landowner should be entitled to enjoin nuisance invasions that curtail his fundamental liberties.231 Libertarian concerns also indicate that every landowner should possess rule three entitle-

230 In some situations the plaintiff may be restricted to the damage remedy alone. See text at notes 231-40 infra.

231 See text at notes 208-12 supra. There is widespread agreement that it is useful to single out liberties other than the right to be protected from unfair wealth redistributions. See J. Rawls, supra note 30, at 60-61, 244-48, 541-48; Calabresi \& Melamed, supra note 11, at 1102-05. There is little agreement, however, concerning which liberties are to be protected, though many scholars include basic bodily integrity, basic political rights, and basic rights of self-expression and self-determination. On the difficulty of identifying basic liberties and providing for the resolution of conflicts when liberties are incompatible, see Grey, Book Review, 25 Stan. L. Rev. 286, 308-16 (1973). 
ments that protect him from liability for exercising certain freedoms ${ }^{232}$ and immunize him from the risk that a neighbor will stop these activities by purchasing the right to their termination through rule four. A landowner's basic rule three entitlement should be that his activities may not be disturbed unless a neighbor can make out a prima facie case in nuisance against him. ${ }^{233}$ In addition, rule three protection is warranted even when activities are unneighborly, to the extent that those activities constitute exercises of fundamental rights of free expression. Bizarre architecture or landscaping may be as significant a mode of self-expression as unusual clothing or hairstyles, activities lately protected by rule three. ${ }^{234}$ In the famous case of People $v$. Stover, ${ }^{235}$ for example, a landowner argued that he strung offensive clotheslines of rags to express disapproval of local tax policy. Activities such as noise from political meetings, playing musical instruments, or burning incense in religious rituals might conceivably warrant rule three protection.

When the plaintiff makes out a prima facie case in nuisance, how-

232 Cf. New York Times v. Sullivan, 376 U.S. 254 (1964) (imposition of liability for alleged defamatory statements may abridge constitutional rights to free expression).

233 For example, a doctor whose examining room is unusually sensitive to noise should not be allowed to invoke rule four to purchase involuntary promises of silence from his normal neighbors. This allocation of rights favors people who create nuisances over those who are hypersensitive. Except where the plaintiff is entitled to a rule one injunction or wants to purchase a rule four injunction, an unneighborly landowner can force a nuisance on his normal neighbors, but a hypersensitive landowner cannot compel neighbors to terminate normal activities that are incompatible with his hypersensitivities. The only apparent justification for this asymmetry is that easements protecting hypersensitivities are perceived as interfering more with the servient landowner's rights than easements legitimizing unpleasant neighboring conditions. This perception is reflected in First Amendment cases that treat loss of the right to speak, the impact of an easement of silence, as a more disturbing deprivation of freedom than interferences with a person's preference not to hear, the effect of an easement of noise. But see the argument for the primacy of "the right to be left alone" in Olmstead v. United States, 277 U.S. 438, 478 (1928) (Brandeis, J., dissenting).

234 Government bodies have had considerable difficulty winning rule one entitlements against eccentric appearances. See, e.g., Cohen v. California, 403 U.S. 15 (1971) (wearing jacket bearing the words "Fuck the Draft" in corridor of courthouse constitutionally protected from collective sanctions); Tinker v. Community School Dist., 393 U.S. 503 (1969) (wearing of black armbands in public school constitutionally protected from collective sanctions). On the issue of the regulation of hairstyles in public school systems, compare Breen v. Kahl, 296 F. Supp. 702 (W.D. Wisc. 1969) with Ferrell v. School District, 392 F.2d 697 (5th Cir.), cert. denied, 393 U.S. 856 (1968). The Supreme Court has denied rule two remedies in externality cases on constitutional grounds. New York Times v. Sullivan, 376 U.S. 254 (1964). I know of no First Amendment case in which the government agreed to compensate a constrained individual for his losses and the individual challenged its right to do so; in most cases such government condemnation of First Amendment and privacy rights would probably not survive constitutional scrutiny.

23512 N.Y.2d 462, 191 N.E.2d 272 (1963). 
ever, most courts readily deny defenses based on constitutional rights of freedom of expression. ${ }^{236}$ This disdain for freedom of expression defenses in nuisance cases is doubtlessly attributable to the easy availability of other means of expression to landowners. Restrictions on land use activities do not curtail individual liberties as sharply as restrictions on hairstyles, for example, because the unneighborly activity can be carried out in a more isolated location. For similar reasons the Supreme Court has tolerated imposition of reasonable restrictions on the time and place of even political expression. ${ }^{237} \mathrm{Al}-$ though it will rarely be recognized in land use cases, the defense of freedom of expression serves as a useful reminder that maximization of wealth and the assurance of its fair distribution are not the sole social goals.

2. The Defense of Equality of Opportunity. Unavoidable physical characteristics of a landowner may be perceived as unneighborly and thus cause an unusual decline in his neighbors' property values. In a society valuing equality of opportunity, however, rule three should be used to protect people with unpopular racial, ethnic, or morphological characteristics from liability and coerced disruptions. Rawls, who would permit social and economic inequalities only if they are attached to positions open to all, ${ }^{238}$ would clearly regard the assessment of liability against unalterable personal attributes as unjust.

The issue of external costs resulting from low social status is considerably more complex. In a society in which high status positions may be achieved by anyone within a short time, nuisance liability for low social status might be accepted as fair. In reality, however, in even the most mobile societies major shifts in social class are exceptional even over a span of several generations; in most cases a person in a low social class can do little to escape that position. In light of this fact, the Rawls test indicates that low social status should not be treated as a nuisance, and the case law concurs. ${ }^{239}$ Plaintiffs seeking damages in a

236 Courts have even upheld the dictation of architectural styles in historic districts. Michelman, supra note 193, at 39-40.

237 "The rights of free speech and assembly, while fundamental in our democratic society, still do not mean that everyone with opinions or beliefs to express may address a group at any place and at any time." Cox v. Louisiana, 379 U.S. 536, 554 (1965). See also Adderley v. Florida, 385 U.S. 39 (1966) (affirming convictions arising from demonstration at jailhouse).

238 J. RAwls, supra note 30 , at 60 .

239 See Falloon v. Schilling, 29 Kan. 292 (1883) (asserting as dictum that injunctive relief should not be available against a person who brings a different social class of people into a neighborhood, even if he is motivated by spite); cf. Cawley v. Housing Authority, 146 Conn. 543, 152 A.2d 923 (1959) (holding on different grounds that a state public housing project did not constitute a nuisance). 
nuisance suit should be denied compensation for losses caused by unavoidable characteristics of an unneighborly landowner or his invitees. Similarly, a plaintiff seeking a compensated injunction should not be entitled to coerce the removal of people whose status or physical characteristics he finds objectionable.

The impact of the defense of equality of opportunity can be seen by imagining the installation by hillbillies of a mobile home in an exclusive residential area of Beverly Hills not protected by covenants. Although mobile homes are certainly unneighborly uses in Los Angeles County, the offended neighbors could only either recover compensation for the damage caused by the physical appearance of the mobile home ${ }^{240}$ or purchase an injunction compelling the amelioration of its noxious aesthetic features. Forced removal of the hillbillies through rule four would be barred by the equality of opportunity defense.

The distinction between damage inflicted by unavoidable personal characteristics and damage inflicted by land use activities is not always clear. A mobile home or tarpaper shack may not be inherently unaesthetic. Uses of this type are probably considered ugly, thereby reducing surrounding property values, because they are associated with people of low social status. If this hypothesis were built into the law, owners of all types of residential structures would be entitled to rule three protection to prevent aesthetic damages from fostering class exclusion. The distinction between people and structures, however, has its advantages. Although no one exercises significant control over his social class, poor people have considerable flexibility in the appearance of their dwelling. The exemption of all residential structures from nuisance liability could create serious allocational inefficiencies since most landowners are generally the best avoiders of costs caused by changes in physical conditions within their boundaries. Even though the wealth redistribution to poor people effected by a residence exemption is desirable, such a redistribution would be best accomplished through direct transfer payments under a general welfare system. A given wealth distribution almost certainly can be achieved much more efficiently through direct transfers than through contortions in liability rules.

3. The Defense of Hypersensitivity. As now stated the prima facie case for nuisance generally imposes liability on a host landowner for external losses caused by intentional or natural changes on his property. This rule was prompted by consideration of the four guidelines

240 These damages would be valued as if the mobile home were occupied by people of normal social status. 
for the efficient assignment of rights. The first three of these guidelines suggested that the risk of loss was better borne by the party with greater knowledge of the risk, better organization for dealing with the risk, and better control over implementing the most efficient preventive measures. The general rule placing liability on the landowner must now be modified to deal with those types of cases where the affected neighbor, not the landowner, typically has better knowledge, organization, and/or control over at least part of the potential loss. This relationship occurs primarily where the neighbor is hypersensitive to harm or where he fails to mitigate damages after a change on the landowner's property. In hypersensitivity cases the neighbor generally has better knowledge of the risk; in mitigation cases he is at least equally aware of the risk of further damage and controls the property on which the most efficient preventive steps can be taken. Efficiency defenses based on these two situations, unlike the liberty defenses discussed above, should not entitle the defendant to rule three protection, but should rather benefit him by shifting more in his favor the assessment of payments due under rules two and four.

Instances of damage from market competition can illustrate that a party injured by another's action is often best able to avoid that loss. Redistributions of wealth caused by market competition are generally not treated as occasions for compensation. ${ }^{241}$ If a large supermarket opens next to a mom-and-pop grocery, destroying the value of the latter's goodwill and diminishing the market value of its building, mom and pop usually bear those losses. One reason they receive little sympathy is that they were probably the best avoiders of the losses they suffered. They probably had the best knowledge of their precarious competitive position and were in the best position to adopt preventive measures, in this case technological advances in their industry.

This laissez faire attitude results from the impact of efficiency considerations on collective assessments of the fairness of private wealth redistributions. Successful competitors are usually not viewed as wrongdoers since free competition is perceived as promoting optimal allocation of resources through the market mechanism; further, losses from competition are so common that the administrative costs of arranging settlements would be excessive. Economists advise that losses from competition will add to efficiency in the long run, since the resources of the injured party will eventually be more optimally employed than

241 When compensation is paid to those injured by market competition, it usually comes exclusively from the public treasury, as in cases of unemployment insurance or subsidies to impacted industries. 
before. ${ }^{242}$ Michelman would consider the general rule denying compensation to be equitable ${ }^{243}$ since mom and pop should be able to judge that they, or people like them, will be better off in the long run if liability is not imposed for damages from market competition. For this class of losses a laissez faire distribution of rights appears to be efficient and fair.

Similarly, for some land use conflicts it will be both efficient and fair to assign at least part of the risk of loss to the neighbor to encourage him to take precautions that limit his potential damages. In accident law the doctrine of contributory negligence is used to induce the victim to take precautions; the counterpart to contributory negligence in nuisance cases is the denial of relief where the plaintiff's land use activity is damaged due to its hypersensitivity to injury. ${ }^{244}$ The hypersensitivity doctrine was decisive in Amphitheaters, Inc. v. Portland Meadows. ${ }^{245} \mathrm{~A}$ racetrack and a drive-in movie theater were built virtually simultaneously on adjacent plots of land. The track's lights shone directly on the drive-in's screen, causing a serious deterioration in the quality of the picture and thereby prompting the owner of the drive-in to seek damages. The Oregon Supreme Court held that light is not inherently harmful and denied the claim for damages on the ground that the injury was caused by the unusual sensitivity of the plaintiff's land use. ${ }^{246}$

242 Demsetz, The Exchange and Enforcement of Property Rights, 7 J. Law \& Econ. 11, 25-26 (1964).

243 For a summary of Michelman's fairness test, see note 30 supra; cf. text and note at note 69 supra. See also J.S. Mill, On Liberty, in UTILITARIANism, LiberTy, and REPREsentaTive Government 202 (Everyman's ed. 1951): "Whoever succeeds in an overcrowded profession, or in a competitive examination; whoever is preferred to another in any contest for an object which both desire, reaps benefit from the loss of others, from their wasted exertion and their disappointment. But it is, by common admission, better for the general interest of mankind, that persons should pursue their objects undeterred by this sort of consequences." But see 3 W. Blackstone, Commentaries *218-19 (establishment of a competing fair, market, or ferry is an actionable nuisance). The English approach, as reflected in Blackstone, did not sit well across the Atlantic. See Proprietors of the Charles River Bridge v. Proprietors of Warren Bridge, 36 U.S. (11 Pet.) 420, 551-53, 562-63 (1837).

244 The REstatement (SECOND) OF TORTs will apparently allow both contributory negligence and the hypersensitivity of the plaintiff's land use as defenses. Compare $\S 840 \mathrm{~B}$ with $\S 821 \mathrm{~F}$, comment $d$ (Tent. Draft No. 16, 1970). See also W. Prosser, TorTs, supra note $147, \S 87$, at 579 . The hypersensitivity issue was involved in most of the old cases discussed in Coase's landmark article. Coase, Social Cost, supra note 2; see, e.g., Sturges v. Bridgman, 11 Ch. D. 852 (1879) (sensitivity of doctor's consulting room to noise); Cooke v. Forbes, L.R. 5 Eq. 166 (1867) (sensitivity of bleach involved in manufacturing process to fumes); Bryant v. Lefever, 4 C.P.D. 172 (1879) (sensitivity of chimney location to blockage of drafts); Webb v. Bird, 10 C.B. (N.S.) 268, 142 Eng. Rep. 455 (1861), aff'd, Exch. 13 C.B. (N.S.) 841, 143 Eng. Rep. 332 (1863) (sensitivity of windmill to blockage of wind).

245184 Ore. 336, 198 P.2d 847 (1948).

246 The court's total denial of damages in Amphitheaters may have been justified since 
The four guidelines for efficient assignment of rights also call for denial of relief in cases like Amphitheaters. A particularly delicate neighbor is more likely than the surrounding landowners to be aware of the risks inherent in his hypersensitivity. The neighbor should also have greater knowledge about the nature of his special condition and be better equipped to assess available preventive measures. The guideline on superior knowledge thus suggests that the neighbor bear the risk of loss for that part of the damage attributable to his hypersensitive condition. That assignment of rights will conserve the resources that would otherwise be spent on conveying information about hypersensitivities. The rarity of the neighbor's vulnerability also reduces fear about difficulties in organizing the injured class for bargaining purposes. ${ }^{247}$ Thus the second guideline does not support the liability of a host landowner to a hypersensitive neighbor. The third guideline, favoring liability on the party having superior control, is neutral in this context. The simplicity guideline indicates that recognition of the hypersensitivity defense will result in added administrative costs; nevertheless, the efficiency gained from denying damages attributable to unusually sensitive aspects of a plaintiff's activities will probably exceed these added administrative costs, thus justifying the departure from guideline four. The defense of hypersensitivity should also be perceived as fair by people able to see the long-term advantages to them of an efficient set of liability rules.

The defense of hypersensitivity requires a method for identifying hypersensitive land conditions or uses. ${ }^{248}$ This method necessarily in-

many landowners consider additional light at night beneficial. If the racetrack's light is perceived as unneighborly under Portland standards, however, the defendant should have been required to compensate the plaintiff for the losses he would have suffered if his land use had been normally sensitive to light, provided that damages met the substantial harm requirement. When the hypersensitivity defense has been recognized, however, it has usually operated as a complete defense.

247 The drive-in involved in Amphitheaters actually succeeded in persuading the track to place hoods over its light stanchions.

248 If the plaintiff, and not his activity, is hypersensitive, he should not be able to recover for any perceived subjective damage to his property. Damages should be measured by the drop in market values, reflecting the tastes of people of general sensitivity. If the plaintiff suffers personal injury because of his special sensitivities, he should also not be able to recover special damages in a nuisance action. See Restatement (SECOND) of TorTs § 821F, comment $d$ (Tent. Draft No. 16, 1970).

The hypersensitivity of a plaintiff's activities should also be distinguished from the hypersensitivity of topographic features of his parcel. When a landowner is unable practicably to alter natural topographic conditions, he is rarely the most efficient avoider of losses in the value of his land. For example, if a normally constructed hillside residence has its view blocked in an unneighborly way, that residence should recover for the lost view. If the house had been unusually designed to take advantage of the view, however, some of its loss could be attributed to its hypersensitivity. 
volves empirical examination of the relative vulnerability to harm of prevailing land uses in the relevant community. To hold down the administrative costs of determining hypersensitivity, a wide band of activities should not be susceptible to the classification. For example, normal residences and predominant construction and dimension patterns should not be characterized as hypersensitive. The defense might be employed, however, by a grocery located among the luxury homes of the Santa Monica Mountains. If the damage caused by a grocery to its neighbors would be only minor in most residential areas, but there is additional damage to the luxury homes in the Mountains, the grocer should be able to raise the defense of hypersensitivity against this incremental component of the damage. In this example the very rich are hypersensitive and must bear some of the risk of not finding a haven for their homes.

The geographic flexibility of this defense can be illustrated by the fact situation in Miller $v$. Schoene. ${ }^{249}$ The defendant's ornamental cedar trees were host plants for a disease that was highly infectious to his neighbor's apple trees. If the case had arisen in Nevada, where apple trees are rare, the apple grower would bear the risk of loss since his land use would be regarded as unusually sensitive under the standards of that state. Miller arose in Virginia, however, where apple growing is a major industry and clearly not hypersensitive. If cultivation of apple trees is so widespread in Virginia that most landowners know about the danger of cedar trees, growing cedar trees would be perceived as unneighborly and their owners should bear the risk of infecting apple trees. ${ }^{250}$

The common law doctrine of lateral support is another example of legal recognition of hypersensitivity. An excavator was held strictly liable at common law for the external damage that his excavation would have caused had the neighboring land been in its natural state; he was liable only in negligence if part of the damage was caused by the weight of structures on the neighboring land. ${ }^{251}$ This distinction was

249276 U.S. 272 (1928). This case has been the focus of a spirited exchange. Samuels, Interrelations Between Legal and Economic Processes, 14 J. LAw \& Econ. 435 (1971); Buchanan, Politics, Property, and the Law: An Alternative Interpretation of Miller et al. v. Schoene, 15 J. Law \& Econ. 439 (1972); Samuels, In Defense of a Positive Approach to Government as an Economic Variable, 15 J. LAw \& EcoN. 453 (1972).

250 Miller is a troublesome case in part because the damage may have been accidental; landowners who planted cedar trees may not have known of the potential injury their trees could inflict on apple orchards. This problem is not present in the usual nuisance cases where the harm can be characterized as intentional. In addition, cedar trees may be wild, not artificial, and the law has been hesitant to impose liability for unneighborly natural conditions in rural areas. See text at notes 169-71 supra.

251 J. Cribbet, Principles of the Law of Property 293-94 (1962). 
developed in rural English society where lot sizes were rather large. Where land parcels are ample, neighbors who unnecessarily build near their lot lines and expose themselves to loss of lateral support are hypersensitive and deserve less favored legal treatment. ${ }^{252}$

The most difficult cases are those in which the plaintiff has made his land use hypersensitive to injury and the defendant is aware of the plaintiff's unusual state but nevertheless proceeds to damage him. A basic reason for the hypersensitivity defense, superiority of the plaintiff's knowledge of the risk, is negated when the defendant is aware of the plaintiff's condition. In negligence law the doctrine of last clear chance places the risk of loss on the defendant even though the plaintiff is contributorily negligent, where the defendant is better informed about the possibility of injury (the inattentive plaintiff) or is in a better position to prevent harm (the helpless plaintiff). Although analogous fact situations are common in land use conflicts, nuisance law has no analogous doctrine.

The possible utility of such a doctrine is illustrated by Fontainebleau Hotel Corp. v. Forty-Five Twenty-Five, Inc., ${ }^{253}$ a conflict between neighboring Miami Beach hotels. The Eden Roc Hotel had located its swimming pool area at the southern edge of its parcel, where the sunlight could be easily blocked by buildings constructed at the northern end of the adjacent Fontainebleau parcel. When Fontainebleau began building a fourteen-story addition only twenty feet from its northern lot line, the Eden Roc sought to enjoin further construction because its swimming pool area would be in the shade after two o'clock in the afternoon during the prime winter season. The appellate court denied relief because the right to protect preexisting natural light sources is not recognized in the United States.

The judicial approach to Fontainebleau suggested by this article would be considerably different. The Eden Roc could make out a prima facie case in nuisance if the height of the Fontainebleau addition would be considered unneighborly in the Miami area. The Eden Roc had made itself hypersensitive to injury, however, by placing its swimming pool at the southern end of its parcel; this location had been freely chosen, probably to avoid the shadow cast by its own hotel. The defense of hypersensitivity would limit the damages recoverable by the Eden Roc to the loss in land value caused by the Fontainebleau's unneighborly shadow plus the loss in value that a normal use would have

252 The common law would have been more precise if, rather than shifting the basis of liability from strict liability to negligence, it had kept strict liability but honored the defense of hypersensitivity.

253114 So. 2d 357 (Fla. Ct. App. 1959). 
suffered had it been located on the Eden Roc parcel. The Eden Roc thus would not be compensated for that part of the loss that resulted from the unusual sensitivity of its land use.

A last clear chance doctrine might seem appropriate in this case since the Fontainebleau was certainly aware of the vulnerability of the Eden Roc's swimming pool. The analogy to accidents, however, is not clearly compelling. Unlike accidents, nuisances are intentional and usually evolve gradually enough to permit the parties to negotiate changes in conduct. Helpless plaintiffs thus are not a problem in nuisance cases, but inattentive plaintiffs are a problem, and the Eden Roc may have been inattentive. Assume the total property value of Miami Beach would be increased if the Fontainebleau redesigned its addition to be less disruptive. An optimal set of liability rules would then assure that the Fontainebleau would sell an easement of light and air to the Eden Roc at a price targeted by rule four. Since the Fontainebleau should be aware that the Eden Roc might compel the termination of its project later, the Fontainebleau has nothing to gain by not informing the Eden Roc of the prospective project at an early stage. Informing the Eden Roc, however, does not benefit the Fontainebleau since it can be compensated for the expenditures on the nuisance project up to the time that the Eden Roc gets a rule four injunction. The problem then is to induce the Fontainebleau to broadcast its plans before the project is far along. An incentive to inform could be created by imposing an enforceable legal duty ${ }^{254}$ on a defendant planning a prospective nuisance to give early warning to neighbors who he should know will be hypersensitive to it. This rule would tend to assure early bargaining in conflicts between hypersensitive plaintiffs and nuisance defendants. The magnitude of the rule's administrative costs, for example determining the defendant's knowledge of the plaintiff's condition, will determine whether such a rule is efficient. The courts that have faced these fact situations, however, have not yet considered imposing a duty to warn..$^{255}$

254 For example, a breach of the duty to inform could subject the defendant to liability for the full drop in the market value of the plaintiff's land caused by his nuisance.

255 In Levy v. Brothers, 4 Misc. 48, 23 N.Y.S. 825 (1893), the defendant to protect his privacy, blocked off plaintiff's windows situated at their common lot line. The court denied relief, stating: "It will not do for a man to build at the extreme end of his lot, and then complain because his rear neighbor, in exercising the same privilege, has cut off the light, air, or prospects he formerly enjoyed. He should not rely upon the generosity of his neighbor, and must depend upon himself, by reserving space enough on his own land for all his requirements-light, air, and vision included." Id. at 50, 23 N.Y.S. at 826; cf. Scharlack v. Gulf Oil Corp., 368 S.W.2d 705 (Tex. Civ. App. 1963), denying relief although defendant's billboard virtually covered plaintiff's. In another case the defendant erected a service plaza with lights that damaged the picture quality at the plaintiff's 
4. The Defense of Failure to Mitigate Damages. A major flaw in existing nuisance law is its disregard for the sequence of actions of the parties to a conflict and its consequent failure to induce a plaintiff to minimize damages by adopting measures uniquely within his control. ${ }^{256}$ Although the duty to mitigate damages is imposed in many areas of the law to provide such incentives, it is rarely recognized in nuisance cases. The efficiency considerations that lead courts to impose a duty to mitigate in tort and contract cases, however, also hold in nuisance cases. The lack of such a doctrine for land use conflicts is particularly unfortunate since the cases generally involve continuing harms to plaintiffs and thus present many opportunities for mitigation. A neighbor who is aware of a nuisance often has special knowledge about possible preventive actions he can take on his property and is always in the best position to execute such measures. If sulphur is blowing from a landowner's pile and corroding steel beams stored in his neighbor's yard, the neighbor should have some incentive to apply tarpaulins or oil coatings to protect the steel from further damage;257 arranging for such action is more expensive for the owner of the sulphur pile.

The need to deter landowners from aggravating injuries by initiating incompatible uses in the face of known dangers is even clearer. In negligence cases a plaintiff who voluntarily confronts a known risk may be vulnerable to the defense of assumption of risk. ${ }^{258}$ In the classic land use analogy the defendant builds a brick factory, and the plaintiffs subsequently construct their houses around it. ${ }^{259}$ In a majority of jurisdictions the plaintiffs may recover full damages or obtain injunctive relief on these facts, even though they came to the nuisance. ${ }^{260}$ This

preexisting drive-in theater. The court held for the defendant even though it should have known about the plaintiff's vulnerable condition. Belmar Drive-In Theatre Co. v. Illinois State Toll Highway Comm'n., 34 Ill. 2d 544, 216 N.E.2d 788 (1966).

256 The Restatement of Torts (1939) completely ignored the sequence of the plaintiff's and defendant's activities in nuisance cases; recent drafts of the RESTATEMENT (SECOND) of ToRTs indicate that it will be at best a small improvement. See note 260 infra. Prosser observes that "once the nuisance is established and the interference with [plaintiff's] rights has begun, he may be required to take reasonable steps to guard against further harm." W. Prosser, Torts, supra note $147, \& 91$, at 610 .

257 Cf. Associated Metals \& Min. Corp. v. Dixon Chem. \& Research, 82 N.J. Super. 281, 197 A.2d 569 (1963).

258 See W. Prosser, Torts, supra note 147,868 , at 440, 445-52.

259 Cf. Hadachek v. Sebastian, 239 U.S. 394 (1915), discussed at length in Michelman, Property, supra note 21, at 1237-45.

260 See, e.g., North American Cement Corp. v. Price, 164 Md. 234, 164 A. 545 (1933); Ensign v. Walls, 323 Mich. 49, 34 N.W.2d 549 (1948); Brede v. Minnesota Crushed Stone Co., 143 Minn. 374, 172 N.W. 805 (1919); Mahone v. Autry, 55 N.M. 111, 227 P.2d 623 (1951); Riblet v. Spokane-Portland Cement Co., 41 Wash. 2d 249, 248 P.2d 380 (1952), 45 Wash. 2d 346, 274 P.2d 574 (1954); W. Prosser, Torts, supra note 147, \& 91, at 611. But see, e.g., Oetjen v. Goff Kirby Co., 49 N.E.2d 95 (Ohio App. 1942); Powell v. Superior Portland 
article suggests that such a result is inefficient and inequitable. ${ }^{261}$ The landowners surrounding the factory, if they invoke rule two, should be limited to damages ${ }^{262}$ measured by the diminution in the value of their property as it existed when the factory was first built. ${ }^{263}$ The neighbors who persisted in building residences on vacant lots in the face of the factory have failed to mitigate damages. To allow them recovery for any diminution in the value of subsequent improvements caused by the fac-

Cement Co., Inc., 15 Wash. 2d 14, 129 P.2d 536-(1942); Rex v. Cross, Car. \& P. 483, 172 Eng. Rep. 219 (1826). See also Annot., 42 A.L.R.3d 344 (1972).

The most recent draft of the Restatement (SECond) of TorTs (Tent. Draft No. 16, 1970) illustrates the current confusion surrounding this issue. Section $840 \mathrm{C}$ asserts that assumption of risk is to be a defense in nuisance cases to the same extent as in other tort actions, but section 840D, entitled "Coming to the Nuisance," then hopelessly clouds the issue: "The fact that the plaintiff has acquired or improved his land after a nuisance interfering with it has come into existence is not in itself sufficient to bar his action, but is a factor to be considered in determining whether the nuisance is actionable." This section invites unprincipled decisions based on an undefined balancing process and fails to distinguish cases where the plaintiff has improved his property subsequent to initiation of the nuisance from those where he has simply subsequently acquired it. This error probably arose because judicial opinions employ the phrase "coming to the nuisance" to cover both situations; the distinction, however, is important. Denying recovery to a plaintiff because he purchased an improvement that preexisted the nuisance is clearly erroneous, unless his predecessor in title had recovered permanent damages. If subsequent purchasers are denied recovery, landowners near existing nuisances will suffer diminutions in the value of their assets; prospective buyers will be willing to pay less for the land due to inability to recover future damages. Externalization of part of the cost of the nuisance must result. The "coming to the nuisance" defense has merit, however, as a device to keep the plaintiff from aggravating his damage by installing incompatible improvements in the face of a preexisting nuisance.

261 Accord, Baxter \& Altree, supra note 2, at 3-5.

262 Permanent damages are appropriate if the activity level of the brick factory is seen as relatively fixed for the indefinite future. If the factory is likely to expand its activities over the years, the plaintiff might prefer to sue periodically for time-to-time damages. If the plaintiff also expands his own incompatible land use incrementally, the sequence of the parties' acts may become quite complex and make the measuring of the appropriate damage award an heroic task. When these problems exist, a simpler rule on sequencing could be preferable.

263 The best starting point for the duty to mitigate is not necessarily the time the harmful spillovers first appear. The homeowners would have failed to mitigate damages if they built their houses after the prospective construction of the brick factory was publicized, even if that publicity occurred before construction was completed. Imposing the duty at the time of first publicity, however, would encourage publicity of many projects that are unlikely to be completed. To solve the dilemma for airports, which often take a decade to build, Baxter and Altree would require the airport authority to file a declaration of intent to build and make the authority liable on abandoning the project for prevention expenditures incurred in reliance by homeowners. Baxter \& Altree, supra note 2, at 5-11. This system seems a bit cumbersome for more common nuisance activity. An alternative system, with obvious ambiguities in some situations, would be to impose a duty to mitigate on the plaintiff when defendant's harmful project had progressed far enough to be virtually certain of completion, provided the plaintiff knew or should have known the unpleasant characteristics it would have. 
tory would increase the incidence of factory-homeowner conflicts since the factory cannot cheaply purchase from them the promise not to build.

Imposition of the duty to mitigate damages may be opposed because it may enable the first land developer of a neighborhood to set the land use pattern for the community at the price of paying for the diminution in the value of the land surrounding his use. If the injured neighbors attach some subjective value to their land, however, and organization costs are low, they will exercise their rule four entitlement and terminate the preexisting nuisance at the price of compensating its sponsor. ${ }^{264}$ If organization costs are high they could still attempt to persuade an appropriate government to purchase the termination of the factory.

Requiring mitigation of damages should help resolve the most frequently discussed hypothetical in the literature of external costPigou's example of a locomotive producing sparks that threaten to ignite farmers' crops along its tracks. ${ }^{265}$ Coase criticized Pigou for assigning the risk of loss to the railroad; he feared that farmers would disregard the high risks and continue to plant inflammable crops since they could recover damages for their losses indefinitely. ${ }^{266}$ Coase is correct in believing that Pigou had oversimplified the solution. As a general proposition it is efficient to make the railroad bear the risk of loss since it has the best information about the risk of sparks and about anti-spark devices. In some cases, however, the railroad should be able to raise the farmer's failure to mitigate damages as a defense. A farmer who is aware of the risk of sparks and nevertheless plants a flammable crop adjacent to the tracks and loses it to fire should not recover the crop's value; compensation should be limited to the diminution in the value of his land resulting from inability to devote it to uses endangered by sparks. ${ }^{267}$

Nuisance law has generally failed to recognize the wisdom of dividing the damage in these situations. An example of this refusal to split losses is found in Le Roy Fibre Co. v. Chicago, Milwaukee, o St. Paul $R y$. Co., ${ }^{268}$ a case remarkably similar in its facts to Pigou's hypothetical.

264 See Spur Industries, Inc. v. Del E. Webb Dev. Co., 108 Ariz. 178, 494 P.2d 700 (1972); text and notes at notes 221-25 supra. In those cases where rule two damages would exceed the collective valuation of the benefits of the nuisance to the defendant, the price of a rule four injunction is zero. See text at note 226 supra.

265 A. Pigou, Economics of Welfare 134 (4th ed. 1932).

266 Coase, Social Cost, supra note 2, at 28-34.

267 Accord, Posner, Killing or Wounding to Protect a Property Interest, 14 J. LAw \& Econ. 201, 211-12 (1971); Posner, Strict Liability: A Comment, 2 J. Legal Studies 205-07 (1973). As to whether the damages should be permanent, see note 262 supra.

268232 U.S. 340 (1914). 
The plaintiff in that case established a factory along a preexisting railroad track and stored highly inflammable flax in an open yard seventyfive feet from the track. Sparks from the defendant railroad's locomotive started a fire that consumed the flax. Plaintiff was awarded full compensation for his loss, the Court rejecting a plea of contributory negligence. The factory, however, had apparently failed to minimize the damages likely to be caused by the sparks since it probably could have readily prevented such losses. Cases like Le Roy Fibre give substance to Coase's concerns. The duty to mitigate damages would reduce the administrative costs involved in assuring that the flax would be placed in a less dangerous position in the future.

\section{Vi. A Tentative Sketch of a More Privatized System of Land USE Regulation}

The analysis thus far has suggested rules for identifying harmful externalities and measuring their severity. There remains the problem of selecting appropriate devices for correcting these imperfections in market operations. This article proposes that private nuisance remedies become the exclusive remedy for "localized" spillovers-that is, those that concern no more than several dozen parties. ${ }^{269}$ Private nuisance remedies, however, are not the optimal internalization system for all types of harmful spillovers from land use activity; in particular private remedies are likely to be an inefficient means of handling insubstantial injuries from "pervasive" nuisances that affect many outsiders. ${ }^{270}$ More centralized systems for internalizing pervasive harms may be capable of achieving savings in administrative costs that outweigh the inevitable allocative inefficiencies of collective regulation. This article will suggest that fines be assessed by a public authority to internalize insubstantial injuries from those pervasive nuisances that present a reasonably objective index of noxiousness. These fines would complement the nuisance remedies that would remain available to persons able to show substantial injury from the pervasive problem. Lack

269 Three factors determine the number of persons injured by a harmful activity: the area of the affected land, the density of landowners and occupants in that area, and the frequency with which outsiders enter that area. The last two factors rise sharply with population density. Highly urbanized areas thus require, and generally have, more sweeping collective regulatory schemes than less densely populated areas.

270 See text and notes at notes 214-15 supra. Courts are generally aware of the limitations of nuisance law. In a class action on behalf of the seven million residents of Los Angeles County, the plaintiff sought billions of dollars in damages and injunctive relief against 300 alleged polluters. The trial court's conclusion that any grant of relief would be beyond its effective capability was affirmed on appeal. Diamond v. General Motors Corp., 20 Cal. App. 3d 374, 97 Cal. Rptr. 639 (1971). 
of an objective index of noxiousness may justify imposition of mandatory standards on pervasive nuisance activity, but such an approach is usually justified only when the public authority is willing to impose standards retroactively. To develop and administer these systems, this article proposes creation of a specialized metropolitan body.

\section{A. The Superiority of Nuisance Law for Localized Harms}

Many land use activities now constrained by zoning ordinances raise only localized threats that would be better handled through private nuisance remedies supplemented by covenants and good manners. The system of private nuisance law outlined above avoids the allocative inefficiencies threatened by mandatory regulations or injunctions. It relies upon a decentralized policing system that is triggered more efficiently than a centralized system, and it can easily be used to internalize existing nuisances, not merely future ones. It also assures the availability of compensation to parties substantially injured by nuisances.

The major drawback of the nuisance approach is potentially excessive administrative costs. Even in localized conflicts, the costs of assessing and distributing payments under rule two or rule four might be so high as to make the nuisance approach inferior to one of its alternatives. ${ }^{271}$ Some economies should be possible, however, through proper structuring of the public administrative apparatus used for handling nuisance disputes. Land use conflicts arise frequently in urban areas and present specialized and repetitive issues. A single adjudicative authority with exclusive jurisdiction over these cases could resolve them with greater facility and consistency than courts of general jurisdiction.

1. Nuisance Boards. The following administrative structure would be a good start. First, the state would enact the nuisance rules suggested above. The state would then establish metropolitan Nuisance Boards and grant them primary jurisdiction over nuisance cases and exclusive rule making power over land use problems in their metro-

271 These costs are largely dependent on the clarity of the nuisance rules and the ease of gathering the determinative facts. The fault system for handling accident losses, not appreciably more complex than the proposed reformulation of nuisance law, has been heavily criticized for its high administrative costs. Calabresi states that the operating costs of the fault system exceed the net awards received by accident victims. G. CALABresi, Cost of Accidents, supra note 11, at 286 n.l. Fact finding in land use conflicts, however, is simpler than in accident cases and often requires little more than taking a few photographs and obtaining subdivision maps from public records. Prior judgments and settlements in nuisance cases must also be easily available to purchasers of affected land to prevent information costs from becoming excessive. Where recordation of judgments or settlements is the predominant method of binding subsequent purchasers, information costs depend heavily on the efficiency of the indexing methods used in the recording system. 
politan area. ${ }^{272}$ Each Nuisance Board would then use this power principally (a) to publish regulations stating with considerable specificity which land use activities are considered unneighborly by that metropolitan population at that time, (b) to identify hypersensitive uses with similar specificity, (c) to establish threshold levels of "substantial harm," and (d) to promulgate schedules of bonus payments for losses of common nonfungible consumer surplus. By thus clarifying entitlements, the Board would assist the private settlement of disputes and thus lower administrative costs. ${ }^{273}$

In adjudicating cases the Board would be authorized to award compensated injunctions and either periodic or permanent damages. ${ }^{274}$ To reduce administrative costs, the Board could assign hearing officers to find facts and determine appropriate awards. These decisions would be reviewable first by the Board and then by courts of general jurisdiction, a pattern of appeals characteristic of many administrative agencies. Where they would simplify Board decisions and encourage private settlements, the Board could promulgate schedules of damages for typical harms. ${ }^{275}$ User fees imposed on litigating parties could also be structured to encourage private settlements.

Whatever the Board's inducements for settlement, several independent factors will tend to reduce administrative costs by limiting the number of cases actually litigated. First, empirical evidence indicates that a mingling of diverse land uses has surprisingly little effect on land values. ${ }^{276}$ If that is the case, the substantial harm requirement will quickly dispose of many conflicts in favor of the defendant. In addition, when the injury is not trivial, the initiator of a harmful use has a strong incentive to undertake it on a parcel large enough to buffer its harms from surrounding neighbors. By internalizing the external costs

272 Since land use control has traditionally been considered a local issue, these boards might be challenged as invading the home rule powers of chartered cities in home rule states. This challenge could be answered by a demonstration of the statewide interests affected by land use regulation.

273 The Board could also administer more collective regulatory systems. See text at notes 297-318 infra.

274 For examples of the use of permanent damages, see Harrisonville v. W.S. Dickey Clay Mfg. Co., 289 U.S. 334 (1933); Spaulding v. Cameron, 38 Cal. 2d 265, 239 P.2d 625 (1952); Boomer v. Atlantic Cement Co., 26 N.Y.2d 219, 257 N.E.2d 870 (1970).

275 Cf. G. Calabresi, Cost of Accidents, supra note 11, at 202-03.

276 One study found that the presence of mixed uses on interior blocks in several Pittsburgh neighborhoods seemed to have little effect on the value of single-family homes. Crecine, Davis \& Jackson, supra note 2. See also Nourse, The Effect of Public Housing on Property Values in St. Louis, 39 LAND Econ. 433 (1963), finding that the replacement of slum properties with public housing had no demonstrable effect on surrounding property values. These studies did not consider the effect that mixtures may have on an owner's subjective valuation of his land. 
through merger, the landowner saves the administrative costs he would otherwise incur in settling with those he injures. Existing harmful land uses not currently held to be nuisances but considered nuisances under the proposed reformulation-for example, service stations-might also be spontaneously redesigned once their owners recognized their potential liability. Finally, good manners will continue to limit the incidence of nuisances and thus the amount of litigation.

One unavoidable administrative cost of the proposed reforms would be the burden on land use practitioners of learning a new system. In the long run, however, the rules in the nuisance system would probably be more stable than zoning provisions, and thereby reduce the burden of keeping up with the latest legal requirements. In addition, nuisance rules demand less detailed understanding than do zoning rules. In most situations a misconstruction of a mandatory zoning regulation has far more serious consequences than a misestimate of the damages recoverable in nuisance litigation.

Nuisance remedies, whatever their structure, will undoubtedly involve substantial administrative costs, but so do the alternative land use control systems. The nuisance approach will be desirable in situations where its allocative and administrative inefficiencies are less serious than those of alternative systems.

The proposed Nuisance Boards would not be wholly immune from the evils of ineptness, corruption, and discrimination often characteristic of zoning administration. The nuisance approach, however, does correct the three major flaws of zoning identified earlier. ${ }^{277}$ In Professor Calabresi's terminology, private nuisance actions for damages are a system of general deterrence and avoid the high prevention costs of specific deterrence systems like zoning. Second, largely because the standards of conduct are not mandatory, nuisance law can be more effciently applied to preexisting land uses than any system of mandatory regulation. In addition, the suggested nuisance approach is a system of uniform regulation that avoids variation of standards from zone to zone, thus eliminating a primary source of the discrimination and corruption typically found in zoning systems. Although Nuisance Boards will probably not be models of honest government, nuisance cases, unlike zoning changes, present readily reviewable legal issues and thus are more amenable to effective judicial scrutiny.

2. Nuisance Boards in Action. Some examples will illustrate how the nuisance system might apply to localized problems now regulated by zoning.

277 See text and notes at notes 101-17 supra. 
a. Side and rear yards. Construction of a building by a landowner close to his side or rear lot line will generally affect the property values of only one of his neighbors, and never more than three or four, assuming the usual configuration of urban lots. Nearly all localities regulate such construction through mandatory minimum side and rear yard requirements. When enforced, ${ }^{278}$ these restrictions impose massive prevention costs by making a large fraction of urban land unimprovable. Private civil remedies would permit the bargaining out of more individualized solutions, an eminently feasible process in such localized disputes. ${ }^{279}$ Moreover, in a new subdivision the nuisance approach would allow the developer, initially the landowner on both sides of the lot line, great flexibility in determining the side and rear setbacks best suited to consumer demands.

A Nuisance Board would handle conflicts over side yard uses in the following manner. ${ }^{280}$ First, to assist parties in understanding their entitlements, the Nuisance Board would promulgate general rules establishing threshold distances for unneighborly side yard construction in its metropolitan area. If a landowner were violating the threshold, the adjacent neighbor would be entitled to choose between collecting damages under the reformulated nuisance rules and purchasing injunctive relief against the side yard incursion. In negotiating a resolution of the conflict the parties would find targets for settlement in prior decisions

278 Enforcement of these provisions often seems ridiculously strict. A homeowner in San Diego was recently sentenced to a jail term of six months for building a carport four feet too close to his neighbor's property. The sentence was suspended on condition that the defendant remove the carport within thirty days and submit to imprisonment for one weekend. L.A. Times, Aug. 8, 1971, § 1, at B, col. 4. See also Kuchta v. Allied Builders Corp., 21 Cal. App. 3d 541, 98 Cal. Rptr. 588 (1971), where the plaintiff recovered $\$ 5,585$ from a home improvement company that had built a patio roof in violation of side yard restrictions. The Orange County Building and Safety Department had ordered removal of the roof; the regulatory scheme apparently did not permit transfer payments from the homeowner to his neighbors to compensate them for their injuries. An incredible example of the high prevention costs caused by such provisions arose in Washington, D.C., where the rear yard requirements applicable to subway stations were found to be "causing costly, time-consuming delays" in the construction of a multibillion dollar transportation system. Washington Post, Mar. 17, 1972, at C2, col. 2.

279 Conflicts over front yard setbacks and heights are, however, less localized. See text at notes 311-12, infra.

280 There are a number of decentralized approaches to side yard conflicts. A simple change within the zoning framework would be to entitle landowners to a waiver of side yard restrictions whenever the adjacent neighbor agreed to the waiver. Developers of subdivisions could thus always eliminate side yard restrictions within their development. The same change could be accomplished by eliminating side yard restrictions in zoning, and granting all landowners a transferable easement of light and air over the strips of land surrounding their parcels. The nuisance solution is preferable, however, because the proposed nuisance entitlements establish collective targets for appropriate settlement amounts and should thus expedite bargaining. See text and notes at notes 214-30 supra. 
of the Board and in any schedule of damages the Board might issue. Settlements or judgments would be recorded in order to bind transferees of the current owners. Similarly, a developer of a subdivision would record the side yard rules he wished to apply to the internal lot lines in his subdivision.

b. Intermixtures of different land uses. The paramount purpose of zoning is the segregation of land uses into different districts; as discussed earlier, this segregation causes allocative inefficiencies, requires frequent and expensive amendments, and makes equitable administration impossible. ${ }^{281}$ Since more privatized alternatives than use zoning are available, use zoning should be discontinued. The nuisance system, however, despite its general advantages, is unlikely to be the best method of handling pervasive land use conflicts. Harmful spillovers from heavy uses like steel mills may be so widespread that the administrative costs of private nuisance remedies renders inefficient and impracticable use of that system as an internalization device. ${ }^{282}$

Use zoning, however, is not the only available response to the problem of pervasive nuisances. Rather than rely on use zoning, municipalities should deal with uninternalized pervasive harms through fines, varying in magnitude from zone to zone, ${ }^{283}$ and selected uniform man. datory standards. ${ }^{284}$ The effect of this change would not be radical. The threat of suboptimal location of heavy uses was greatly exaggerated in the early zoning literature; market transactions naturally segregate land use to a remarkable extent. Heavy uses in Houston, where there is neither zoning nor a fine system, appear to be as spatially segregated as in most zoned cities. ${ }^{285}$

In addition, use zoning is not primarily concerned with pervasive conflicts. For example, most zoning ordinances try to segregate multiacre estates from modest subdivisions, single-family residences from multifamily developments, and all residential units from light commercial and industrial uses. The nuisance system, buttressed by private covenants, is likely to be superior to zoning for handling conflicts in-

281 See text at notes 31-117 supra.

282 The location of heavy uses that cause pervasive harm-like steel mills, airports, and power plants-is not likely to be efficiently determined by private nuisance suits. Although nearby neighbors who were substantially harmed would collect damages from the sponsors of heavy uses, many insubstantial injuries to landowners farther away would be uninternalized.

283 Cf. Baxter \& Altree, supra note 2; Calabresi \& Melamed, supra note 11, at 1123; Michelman, Book Review, supra note 11, at 685-86.

284 See text and notes at notes 297-318 infra.

285 Siegan concluded that industrial zoning was not needed in Houston. Siegan, NonZoning, supra note 2, at 111-15. 
volving these kinds of uses. First, use zoning is an overreaction to the need to control micro-neighborhood conditions. Although homeowners may believe that construction of a nearby apartment building will depress property values, there is little evidence to support such fears. ${ }^{286}$ Even where intermixture of uses does result in substantial external losses, those losses are usually localized. ${ }^{287}$ In addition, proximity to certain uses may entail benefits that offset external costs; for example, commercial and industrial uses provide opportunities for shopping and employment.

The familiar example of a grocery in the Santa Monica Mountains can be used to demonstrate how a Nuisance Board could handle conflicts between residential and commercial uses. After examining metropolitan sentiment, the Board would probably classify groceries as an unneighborly land use. Nevertheless, because of the benefits of proximity to groceries, it is unlikely that more than a score or so of the grocery's neighbors could prove substantial harm from its operation. If the parties could not reach a private settlement, the uncompensated neighbors could take their case to the Nuisance Board either to collect damages or to purchase the closing of the grocery. ${ }^{288}$ This approach

286 See note 276 supra. Siegan reports that the F.H.A. office in Houston does not lower the valuations of modest single-family homes whose mortgages it insures because of nearby garden apartments, although it often lowers valuations if gas stations or supermarkets are immediately adjacent. Siegan, Non-Zoning, supra note 2, at 103, 106.

287 The probability of the participation of neighboring landowners in Skokie, Illinois, zoning hearings declined by 50 percent for every additional seventy-nine feet that separated the landowner from the site in controversy. T. Tideman, Three Approaches to Improving Urban Land Use, 1969 (unpublished Ph.D. dissertation, Univ. of Chicago, Dep't of Economics). The probability of a landowner participating in such a hearing is no doubt highly correlated with his perception of potential damage to his property values.

288 Measurement of damage in this case would be affected by a number of nuisance doctrines. Los Angeles Board rules would likely specify the value levels (e.g., $\$ 50,000$ ) at which residences (exclusive of their site value) become hypersensitive to damage. Damage attributable to house value over that threshold would not be compensable. Since the Santa Monica Mountains contain many luxurious homes, the grocer could probably successfully raise as a partial defense the hypersensitivity of some of his neighbors. The homeowners, on the other hand, should be awarded bonuses for the losses in subjective value they are likely to have suffered, especially if they are long-time residents. Board rules would, again, provide guidelines for these bonuses.

If the offending use in the Santa Monica Mountains were a federally subsidized garden apartment project for lower income families, the defendant developer would raise as a partial defense not only the hypersensitivity of Mountain homeowners but also the equality of opportunity of his tenants. Any damage attributable to the race or class of the persons who occupy the project would then be excluded from the award. The homeowners could recover their remaining damages from the developer only if the bulk, appearance, noise, or other characteristics of that kind of project were generally viewed as unneighborly in Los Angeles. Again, if those characteristics would have only a slight adverse effect on the value of neighboring property devoted to normally sensitive uses, the residual damage might not be sufficient to meet the substantial harm requirement. 
would be much more likely than the present system to assure the optimal number of groceries, as well as uses like multifamily dwellings, in the Mountains. Undoubtedly the nuisance system will permit groceries to externalize some insubstantial pervasive costs, but allocative perfection-the adoption of all efficient preventive measures-is too administratively burdensome to be desirable.

c. Unneighborly population densities. Zoning regulations may control population densities in many ways. Maximum dwelling unit densities per acre can be explicitly stated for each residential zone; population density per unit can be controlled through limitations on the number of bedrooms per unit and housing codes that limit the number of people who can inhabit a room. Minimum lot sizes, or minimum unit sizes coupled with severe bulk restrictions, may also be used to limit population. These types of mandatory controls are presently considered essential ingredients of community planning efforts. ${ }^{289}$ They are designed to serve two distinct functions: (i) to limit overall future population growth in a wide area and (ii) to prevent unwanted localized concentrations of population. Again, there are better alternatives. "Growth controls" should generally not be exercised except where the restricted landowners are compensated, and concentration problems should be handled primarily through the proposed nuisance system.

"Growth controls" may be defined as governmental measures that restrict the prospective development of land parcels to a population density less than that generally prevailing in developed areas of the relevant metropolitan area. Mandatory growth controls unfairly prohibit owners of undeveloped property from duplicating the developments of earlier landowners; although a new development with a population density identical to the prevailing densities may add to existing pollution problems and increase the congestion of public facilities, it cannot be said that it differs in kind from the developments that preceded it. Growth controls also usually increase the price of entry for people moving into an area. ${ }^{290}$ Residents of a metropolitan area are

289 See, e.g., Lamm \& Davison, The Legal Control of Population Growth and Distribution in a Quality Environment: The Land Use Alternatives, 49 Denver L.J. 1 (1972); cf. Comment, Toward a National Policy on Population Distribution, 47 WASH. L. REv. 287 (1972).

290 Where density controls operate as pure taxes on land rents they have no effect on entry costs. Under those circumstances the entire cost of the restriction is shifted to landowners, and prices of residential units are unaffected; such controls, however, are unlikely to have that effect. Consumers apparently prefer large lots to small ones, and this preference will be reflected in lot prices. In addition, growth controls can raise the price of building sites by limiting their supply. Finally, a house is a complementary good to a lot. As localities mandate increased lot sizes, builders respond by upgrading house designs, effectively increasing entry prices. 
overtly discriminating against outsiders when they apply prospective population density controls that prohibit new development that would be less dense than their existing neighborhoods.

In addition to the possible inequities of growth controls, such controls are usually undesirable on efficiency grounds. ${ }^{291}$ It is doubtful whether a planning agency can make intelligent decisions about the optimum gross spatial distribution of a population. An optimal distribution is more likely to be achieved through private migration decisions than through public regulation. 292 Employers and individuals faced with location decisions naturally weigh the overall advantages of their alternative environments. If a particular area becomes too dense, its residents will perceive the disadvantages of this high density and tend to leave; growth controls are thus not needed to protect people from "un-

291 Although many urban experts consider regulation of population densities essential for rational planning of sewers, highways, schools, and other public works, this justification for density regulation is rather weak. First, as stated in the text, urban growth tends naturally toward equilibrium. If public facilities are not provided, growth will slow because of their absence. When the new town of Reston, Virginia, first opened, the roads between it and Washington, D.C., were grossly inadequate. The result was not continued growth and hopelessly clogged roads, but rather, largely because of poor access, a very modest initial growth rate in Reston. Second, planners of public facilities should not need density controls to obtain useful population projections. The private entrepreneurs who are responsible for most urban growth empirically examine trends in supply and demand to determine when and where they should make incremental expansions in their brand of land improvement. Since converting raw land into a developed area takes many years, it is not hard to detect where growth is occurring and provide new facilities accordingly.

In practice, even where density controls exist, public works planners can rarely rely on them. Installation of huge sewers or wide roads in an area publicly planned for high density development risks being highly wasteful unless there is strong evidence that the area will actually be developed in that way. Thus, public works planners must themselves resort to empirical studies of trends in determining future projects and cannot rely on governmental controls that may be amended at any time. The future densities in any given area may be sharply affected by local economic factors, changes in housing preferences, breakthroughs in housing or land development technologies, national migration trends, national fertility rates, and other developments that cannot be anticipated by any public works planner. His best strategy may be to muddle through by building facilities adequate for the foreseeable future, preserving the possibility of installing larger pipes, additional lanes, or new classrooms at a later date. A final practical problem in using density controls to forecast public works is that the zoning ordinances of most large cities would permit their populations to double or triple. Since most large central cities have also been losing population, these zoning provisions obviously cannot be relied upon for public planning.

Operating a local government without mandatory density controls is not inconceivable. Houston has developed rapidly without them, yet Siegan reports that traffic flows well in Houston. Siegan, Non-Zoning, supra note 2, at 73. Siegan does observe that Houston has had a difficult time predicting demand for sewers, but this problem is also common in localities that try to control density.

292 Cf. Mills, Welfare Aspects of National Policy toward City Sizes, 9 Urban Studies, Feb., 1972, at 117 . 
livable" conditions. ${ }^{293}$ When conditions are unlivable for many residents, emigration will reduce population densities and tend to establish equilibrium. If California's attractiveness as a place to live were to diminish because of rapid population growth and the resulting additions to traffic congestion and air pollution, private forces would end net migration to California; population planning is not necessary to accomplish this result. ${ }^{294}$

When the residents of an area perceive a rapid population influx as "overcrowding," from a national perspective they are hypersensitive in their reaction. Even with the population influx the area must have

293 Commentators do not unanimously agree with this assertion:

Finally, development rights transfer is a pernicious device in today's congested cities. Whether from landmarks, midblock brownstones, or municipal buildings, unused rights will always flow to those areas where the commercial advantages of concentration make transfer economically attractive. If this existing concentration is attended by its usual effects-if the subways and buses are overloaded; the streets, clogged; the air, polluted; and the few remaining open spaces, in the perpetual shadow of surrounding office or apartment towers-then development rights transfer can only make life more miserable.

Note, supra note 32 , at 371 (emphasis in original). It is highly doubtful, however, that developers actually tend to build in locations where life is generally perceived as miserable. For an excellent review of the literature concerning the effects of crowding on the incidence of social pathologies, see Stokols, A Social-Psychological Model of Human Crowding Phenomena, $38 \mathrm{~J}$. AM. Inst. of Planners 72 (1972). If social status factors are controlled for, there is little evidence that pathologies increase with crowding.

294 Pigou thought the need for density controls self-evident:

It should be added that sometimes, when the interrelationships of the various private persons affected are highly complex, the Government may find it necessary to exercise some means of authoritative control in addition to providing a bounty. Thus it is coming to be recognized as an axiom of government that, in every town, power must be held by some authority to limit the quantity of building permitted to a given area, to restrict the height to which homes may be carried,- for the erection of barrack dwellings may cause great overcrowding of an area even though there is no overcrowding of rooms, - and generally to control the building activities of individuals. It is as idle to expect a well-planned town to result from the independent activities of isolated speculators as it would be to expect a satisfactory picture to result if each separate square inch were painted by an independent artist.

A. Pigou, Economics of Welfare 194-95 (4th ed. 1962). The analogy to the painting of a picture suggests that Pigou's main criticism of decentralized density controls is the difficulty in producing communities with desirable aesthetic features on a large scale. Centralized regulation of urban growth is undoubtedly the best method for obtaining highly ordered landscapes, but large scale aesthetics is not the sole consideration in city planning. Centralized direction has serious drawbacks in other regards: it will probably introduce major inefficiencies in the location of land uses, raise serious problems of equity, and threaten the liberties of existing residents. Pigou's analogy is inappropriate. First, its scale is wrong; a person can fully comprehend the problems of painting a picture, but not of planning a city. It is doubtful that Pigou would prefer that all of French painting be made the exclusive business of a National Art Agency, rather than allowing that great tradition to continue to grow through incremental contributions of unorganized private painters. Second, figures on a painting are inanimate objects, but real people and their activities are the media of city planning and not as lightly played with as a set of oil paints. 
above-average national appeal, because immigrants outnumber departing residents. In this situation growth controls are likely to be efficient only when the residents benefiting from the growth controls internalize the prevention costs by compensating the restricted landowners for lost development rights. If, as at present, compensation is not generally provided, the cost of growth controls falls on owners of vacant land and future entrants, two groups with little voting strength. In light of the political weakness of this opposition, the dynamics of local governmental processes systematically generate inefficiently strict regulations on population growth. ${ }^{295}$

The reluctance of most state and local governments to spend large sums for parks and scenic easements is a clue that growth controls are usually inefficient and will remain politically appealing only so long as the cost is generally borne by others than typical taxpayers. A reliable method of preventing the present system's inefficiencies and assuring equal treatment of landowners and outsiders is to avoid growth controls that fail to provide for compensation. ${ }^{296}$

The problem of harmful spillovers from localized objectionable population concentrations, however, raises different issues. One approach would be to limit landowners concerned about such concentrations in their immediate surroundings to self-help protections like buffer parcels and restrictive covenants. Unusually dense real estate developments, however, may create situations not properly dealt with through strictly laissez faire entitlements. Dense residential developments are likely to be considerably noisier and more offensive in appearance than normal neighboring land uses. These unneighborly aspects of a development are proper targets for an internalization system. Localized costs such as noise can be best internalized through private nuisance actions. The unneighborly effects of an unusual population concentration, however, may also involve pervasive, but individually insubstantial, losses such as overburdened street parking. These problems are likely to be best handled through systems of fines and uniform mandatory public standards.

295 Residents receiving benefits from exclusionary ordinances can vote in local elections and are able to identify each other to organize cooperative lobbying efforts. In contrast, outsiders threatened by an exclusionary measure have neither the franchise nor the ability to identify each other. Opposition to exclusionary ordinances is thus left mainly to homebuilders and land speculators.

296 This article does not reach the questions of whether state legislatures, state judiciaries, or other institutions should be more active in policing growth controls and the legal doctrines on which intervention could be based. Its scope is limited to the substantive weaknesses of growth control measures. 
B. The Necessity of More Collective Internalization Systems for Pervasive Harm

A pervasive nuisance may inflict substantial harm on nearby neighbors and also cause legally insubstantial injuries to a large number of more distant parties. Entitlement to nuisance remedies assures those suffering large injuries compensation for their losses. ${ }^{297}$ Use of nuisance remedies to internalize the insubstantial pervasive harms, however, would pose an intolerable administrative burden. One of the more collective internalization systems-fines, regulatory taxes, mandatory standards, mandatory prohibitions ${ }^{298}$ - may prove to be a more efficient intervention by eliminating the task of assessing and distributing many small awards. It might be suggested that insubstantial, pervasive harms should be left uninternalized. Although these injuries are individually insubstantial, however, the total harm may be significant; thus, major allocative efficiencies should be possible if an appropriate internalization device can be found. In addition, when a nuisance is pervasive, the administrative costs of forcing internalization are likely to be justified because of efficiencies of scale of policing; centrally enforced internalization of localized insubstantial injuries, however, is less likely to be efficient.

An informed choice among the more collective systems for internalization would be primarily based on empirical examination of each system's relative administrative costs, and potential for allocative damage. Since many of the options have not been tried, policy prescriptions at this point are necessarily tentative. This analysis suggests, however, that in many instances fines should be tried in the place of mandatory standards and prohibitions as a means of regulating pervasive nuisances.

1. Uniform Standards Enforced Solely through Fines. Welfare economists have historically favored fines as solutions to problems of external cost. Unlike mandatory standards and prohibitions, fines can be applied retrospectively to existing nuisances without imposing the drastic prevention costs that deter many zoning administrators from eliminating nonconforming uses. Fines are also more flexible than mandatory regulations since a landowner is free to buy, in effect, the right to violate an inefficient standard. A system of fines requires establishment of standards for imposition of the fines, rules for calculating their amounts, and an administrative structure for assessment and collection.

Standards can take either of two forms: performance standards, setting

297 Under the Michelman fairness test those insubstantially injured should be able to understand why it is in their long-term self-interest not to be compensated. See note 30 supra.

298 See text at notes 19-20 supra. 
performance levels to be achieved, or specification standards, detailing exact technologies that are, and are not, acceptable. For example, performance standards on light stanchions in gas stations might consist of limits on the lumens detectable at a specified distance; specification standards would list approved or disapproved types of poles, hoods, and bulbs. These approaches can also be used in combination. Performance standards are often praised in the literature, ${ }^{299}$ but are useful only when the allocative flexibility they permit justifies the additional administrative costs, to both the regulator and the regulated, of measuring compliance with the standards. A desirable combination is thus the establishment of a general performance standard and, in addition, the articulation of examples of complying and noncomplying technologies.

The unneighborliness requirement is a general performance standard and may function well as a general standard for identifying conduct to be fined. Fines on activities meeting an unneighborliness test will discourage below normal conduct; as discussed earlier, the fining of normal conduct is rarely efficient because of the frequency of these offenses, and the efficient way to induce above-normal behavior is usually through rewards. Just as administrative costs in nuisance cases can be reduced by regulations identifying unneighborly activities in a jurisdiction, the Nuisance Board should be authorized to write standards for fines and should recognize the advantages of a high degree of specificity in its regulations.

Administrative simplicity is a paramount consideration in structuring the calculation of fines. ${ }^{300}$ For distributional reasons, substantially injured landowners should be permitted to pursue their nuisance remedies. To avoid "overinternalization" the fines must then be calculated to cover only the insubstantial, and thus incompensable, losses inflicted by the pervasive unneighborly activity. ${ }^{301}$ Those losses can be estimated by using the nuisance system, minus the substantial harm requirement, to identify and measure harmful externalities. Certainly the defenses protecting civil liberties and equality of opportunity should be recognized to prevent fining constitutionally privileged un-

299 See, e.g., Hirsch, Measuring the Good Neighbor: A New Look at Performance Standards in Zoning, LAND UsE Controls, No. 2, 1968 at 5; Note, Industrial Zoning and Beyond: Compatibility through Performance Standards, 46 J. URBaN LAw 723 (1969).

300 Localized nuisances could be ruled exempt from fines on the grounds that the pervasive injuries they inflict are de minimis.

301 Cf. Michelman, Book Review, supra note 11, at 675-76. An alternative is for the Nuisance Board to levy fines that internalize all losses, to compensate those substantially injured in the amounts that would otherwise be due them under the nuisance system, and to bar private damage actions against pervasive nuisances. This alternative, however, creates needless complications about the availability of private nuisance remedies and hinders private bargaining over levels of compensation. 
neighborly activities. To simplify administration, however, the Board might decide to disregard the duty to mitigate damages in calculating fines, thus avoiding expensive investigations into the sequence of activities. ${ }^{302} \mathrm{~A}$ brick factory later surrounded by homes would thus be fined for pervasive harm just like the average brick factory. ${ }^{303}$

Monetary penalties could be individually calculated to internalize the precise damage inflicted on the actual neighbors of the offensive activity, the "regulatory taxes" approach, or they could be "fines" based solely on the nature of the offending landowner's conduct, with the mix of surrounding uses assumed to be normal. Fines are simpler, and thus often will be the preferable approach; for example, pollution charges cannot feasibly be calculated to equal the actual external damage of each polluter ${ }^{304} \mathrm{~A}$ middle ground solution may be the best. A regulatory agency might obtain greater allocative efficiency, at additional administrative cost, by combining the two approaches and varying assessments for violations of standards according to the geographic zone in which the offending activity occurs. The amount of the fine would be an estimate of the pervasive damage a violation would normally cause in that mapped zone. ${ }^{305}$ Fines against unusually tall buildings, for example, would be greater in hilly areas or along coast lines than elsewhere, but would be uniformly assessed within each zone. Varying fines among zones would reintroduce some of the arbitrariness and discrimination typical of current zoning systems. The distributional effects of determining the boundaries of zones for fines, however, would not be nearly as dramatic as under current zoning decisions. Present restrictions on heights determine whether or not a skyscraper can be built;

302 Cf. Baumol, On Taxation and the Control of Externalities, 62 AM. Econ. Rev. 307, 312-13 (1972).

303 This approach assumes that the reduction in administrative costs achieved would exceed allocative losses resulting from the absence of any incentive to mitigate. The rationale for imposing a duty to mitigate on homeowners pursuing nuisance remedies is that the costs of investigating sequencing there are lower because fewer parcels are involved.

304 Effluent charges are now used by several cities and the state of Vermont to combat water pollution. Vt. Stat. AnN. tit. 10, § 1265e (1973); Wall Street Journal, July 12, 1971, at 24. They are also often proposed as a method of attack on air pollution. See, e.g., Ruff, The Economic Common Sense of Pollution, Pub. INTERest, Spring, 1970, at 69, 78-85. For a theoretical discussion of problems with this approach, see Dolbear, On the Theory of Optimum Externality, 57 AM. Econ. Rev. 90, 97-103 (1967). Although he continues to view them as the preferred internalization device, Professor Baumol foresees great diffculty in the calculation of fines. See Baumol, supra note 302, at 316-20. Some recent empirical studies of the effects of air pollution on property values, however, provide hope that fines could be rationally estimated. J. Hite, H. Macaulay, J. STEPp \& B. Yandall, THE ECONOMics OF ENVIRONMENTAL QUALITY 46-47 (1972).

$305 \mathrm{~A}$ balancing of administrative costs and allocative consequences would determine the optimal number of zones. 
zones for fines would affect only the developer's cost of construction, not his right to build..$^{306}$

The metropolitan Nuisance Boards would be the logical authority to administer the fine system since those boards would already be involved with the nuisance rules. For flexibility, the Boards could be authorized to levy either periodic fines or permanent fines. ${ }^{307}$ The fines should be lienable and given priority over most other creditors. Actual collection of fines might be handled through the property tax assessor's office.

Although fines are an attractive land use control, they are not necessarily the best system for all types of pervasive nuisances. Fines work best as an internalization device when the harmful activity presents a simple and objective index of noxiousness; the amount of the fine is then easily keyed to that index. If no such index exists, the administrative costs of calculation will be higher, and the amount of individual fines are likely to be so arbitrary that courts will have a difficult time preventing graft and discrimination..$^{308}$ Even where a simple, objective index can be applied, rapid changes in index variables may make fines unworkable by requiring maintenance of expensive monitoring devices. $^{309}$

There are, however, several pervasively harmful land use activities now regulated by mandatory governmental controls that are well suited to being controlled with fines. These activities all present a reasonably objective index of noxiousness that is negligibly volatile over time.

a. Inadequate provision of internal parking. Street parking in crowded urban areas, because it is generally offered at a low price level, is not sufficient to meet the demand for storage space for automobiles. The failure of a landowner to provide a normal amount of internal parking can consequently be perceived as unneighborly. The nuisance remedy, however, may be inefficient where hundreds of landowners who compete for street parking are affected by another's disproportionate claim on that commodity. Local governments now deal with this

306 A sufficiently high fine could have the same allocative consequences as a prohibition. The thirst of government officials for revenues, however, would dampen the inclination to levy fines intended as prohibitions. In addition, the calculation of fines can be made subject to judicial review.

307 Fines on prospective buildings could be estimated at the time of application for a building permit. This early assessment would assist builders in getting commitments for construction and permanent loans. Where permanent fines are assessed, the Board might devise a system of partial rebates for landowners who pay fines and later correct the offensive condition.

308 Fear of these abuses is probably largely responsible for the notable lack of reliance on fines as land use controls in the United States.

309 Fining erratic patterns of air pollution, noise, or other evanescent harm obviously might involve great administrative costs. 
problem by drafting minimum standards for internal parking keyed to housing units, bedrooms, employees, or square feet of floor space..$^{310}$ These mandatory standards are usually prospective only and thus primarily enforced through preconstruction design reviews. If a Nuisance Board were to handle parking problems with fines, it would issue uniform specification standards, based on the same variables as present standards, that specifically identify unneighborly shortages of parking space. Fines for violating these standards would apply to both future and existing uses and would vary among mapped parking zones. Fines might thus run several thousand dollars a space in areas where street parking is scarce, yet be waived completely elsewhere. Administrative costs could be reduced through use of permanent fines, with rebates available to landowners who later corrected, or partly corrected, violations.

b. Overhead utility lines. Utility wires and poles visible to many residents cause pervasive aesthetic damage. Whether the proper internalization device is a system of rewards for underground wires or a system of fines for overhead wires depends on prevailing perceptions of normalcy. High-tension lines are rare enough today to be treated as nuisances; as undergrounding becomes more common, ordinary telephone and electric poles may also come to be viewed as unneighborly. A simple index for calculating fines on utility lines would be the number of poles located in areas above some threshold population density. More sophisticated indexes based on the height of the poles or their proximity to major arteries could be developed at somewhat greater cost. Administration of periodic fines would be relatively inexpensive since there are few utilities and changes in utility networks are incremental and easily monitored by the utility itself.

c. Front yard setbacks. Front yards affect more people than side or rear yards because they determine the light, air, and views available to passing pedestrians and motorists and the ability of those travellers to avoid cross-traffic at intersections. Mandatory front yard setbacks are now imposed prospectively and enforced through preconstruction design reviews. ${ }^{311}$ This problem might be more flexibly handled through a system of fines triggered by violations of specification standards issued by Nuisance Boards. The index for calculating fines might include such

310 See generally D. Witheford, Zoning, Parking and Traffic (1972).

311 Cf. Goreib v. Fox, 274 U.S. 603 (1927), upholding the constitutionality of an ordinance requiring structures to be set back at least as far as 60 percent of the existing buildings fronting the street on the same block. See also Comment, Zoning: Setback Lines: A Reappraisal, 10 Wm. \& MARY L. Rev. 739 (1969); Comment, Building Size, Shape, and Placement Regulations: Bulk Control Zoning Reexamined, 60 YALE L.J. 506 (1951). 
variables as distance from the street, street width, and proximity to intersections.

d. Building heights. Mandatory height restrictions are becoming popular in many coastal cities where skyscrapers are perceived as threatening pervasive harm. ${ }^{312}$ Fines are again a possible alternative; they are easily indexed to height and area of silhouettes. Where a low skyline is strongly valued by the local populace, these fines might be quite large. Since the damage caused by tall buildings on hillsides and coastlines may be greater than on flat lands, it would be efficient to vary the fines among geographic zones. Since the fines would be retrospective, they would provide incentives for the destruction of existing skyscrapers perceived as offensive by a metropolitan population.

2. Mandatory Enforcement of Uniform Standards and Prohibitions. When an activity that causes pervasive harm presents no reasonably objective indexes of noxiousness a system of fines is likely to be both administratively costly and arbitrary. In these instances mandatory enforcement of minimum standards may be the best method for limiting damage caused by pervasive nuisances. Mandatory standards involve great risks, however, and such a system should be compared to the laissez faire approach that is preferable when there is no cost-justified mechanism for internalizing pervasive nuisance injuries. In addition, mandatory standards raise difficult equity issues when they are nonuniform, either among zones or over time due to prospective application. To be fair, standards should generally apply across a given metropolitan area $^{313}$ and, except where obviously inefficient, ${ }^{314}$ should be retro-

312 Shortly after San Francisco voters had defeated two initiative measures that would have imposed strict height limits, the San Francisco Board of Supervisors unanimously approved an ordinance limiting heights in most residential areas to forty feet. House \& Номе, Sept., 1972, at 28. Laguna Beach, California, approved a thirty-six foot height limit by initiative, but the procedures were later held to violate landowners' rights to due process. Taschner v. City Council, - Cal. App. 3d -, 107 Cal. Rptr. 214 (1973). La Jolla, California, has enacted a temporary height limit of fifty feet. L.A. Times, Aug. 4, 1971, at 1, 10. An anti-highrise initiative applicable to coastal areas was approved with 63 percent of the votes in a November, 1972, election in the City of San Diego; the procedures used in the initiative are now under constitutional attack. L.A. Times, Mar. 9, 1973, Pt. II, p. 4.

313 Several zoning critics have advocated the abolition of zones and suggested that uniform standards on site planning and building design apply to uses in all locations. See Pratter \& Ward, A New Concept in Residential Zoning, 1971 Urban Law Annual 133; cf. Davis \& Winston, The Economics of Complex Systems: The Case of Municipal Zoning, supra note 2 , at 444 .

314 Since, for example, the cost of widening streets in existing neighborhoods is much greater than the cost of building wide streets in new subdivisions, street width standards that are prospective only may be more efficient than standards that also apply retroactively. 
spective as well as prospective. Since mandatory restraints on normal behavior are politically unpopular, retrospective mandatory standards are rarely aimed at activities that are not perceived as unneighborly. Where the standards are prospective only, the regulatory agency should usually refrain from forcing above-normal behavior. The Nuisance Board, metropolitan in scope and expert at identifying unneighborliness, could properly be delegated the basic authority to enact and enforce mandatory standards for land use. If an activity complies with the Board's mandatory standards governing it, but is also a nuisance under the nuisance rules, its neighbors should still be permitted to seek damages in a private nuisance action. This entitlement provides internalization where the Board's specification standards are easier to meet than the general performance standard against unneighborly land use activities. ${ }^{315}$

Mandatory standards may be the best land use control system for regulating activities like subdivision design. Subdivision activity may pervasively disrupt the community road, utility, and drainage networks. There is no apparent simple index for assessing fines against violations of normal standards on subdivision design, and regulatory taxes that equal the actual damage inflicted would be both expensive to calculate and difficult for courts to scrutinize. The current system of mandatory subdivision standards is often discriminatory in that new

315 Most cases hold that permissive zoning is not a defense in a private nuisance action. See, e.g., Commerce Oil Ref. Corp. v. Miner, 281 F.2d 465 (lst Cir. 1960); Sweet v. Campbell, 282 N.Y. 146, 25 N.E.2d 963 (1940); Reid v. Brodsky, 397 Pa. 463, 156 A.2d 334 (1959). But cf. Bove v. Donner-Hanna Coke Corp., 236 App. Div. 37, 258 N.Y.S. 229 (1932). See generally Linden, Strict Liability, Nuisance, and Legislative Authorization, 4 Osgoode Hall L.J. 196 (1966); Note, Zoning Ordinances and Common Law Nuisance, 16 SYracuSE L. Rev. 860 (1965); Annot., 166 A.L.R. 659 (1947); Michelman, Book Review, supra note 11 at $676-79$. The cases often fail to consider the kind of relief being sought. Permissive legislation, if silent about preemption of preexisting nuisance law, should be a defense against a private suit for injunctive relief, but not against an action for damages. See Note, Nuisance and Legislative Authorization, 52 Colum. L. REv. 781 (1952).

Many jurisdictions have enacted statutes that expressly restrict liability for damages when a noxious activity is carried out in compliance with statutory standards. For some British examples, see Coase, Social Cost, supra note 2, at 24. Cal. Civ. Proc. Code § 731(a) (West 1954), originally enacted in 1935, provides that if a zoning ordinance expressly permits a manufacturing, commercial, or airport use, that use cannot be privately enjoined "from the reasonable and necessary operation ... nor shall such use be deemed a nuisance without evidence of the employment of unnecessary and injurious methods of operation." This statute properly bars injunctive relief, but might also be construed to bar recovery of damages by neighbors of uses that do not employ "unnecessary and injurious methods of operation." The California courts have fortunately not considered this statute much of a constraint. See Kornoff v. Kingsburg Cotton Oil Co., 45 Cal. 2d 265, 288 P.2d 507 (1955) (damages granted despite permissive zoning, statute not mentioned); Christopher v. Jones, 231 Cal. App. 2d 408, 41 Cal. Rptr. 828 (1964) (limited injunctive relief granted despite permissive zoning). 
subdivisions are commonly required to be above-normal in quality. This discrimination could be avoided by making uniform subdivision standards, where efficient, applicable to both new and existing subdivisions, ${ }^{316}$ and by refraining from prospective controls mandating abovenormal conduct.

Pervasive aesthetic blight might also be an appropriate target for mandatory regulation. Damage from unneighborly signs, for example, is typically pervasive since signs are intentionally placed where many people see them. Assessment of fines might be administratively possible, ${ }^{317}$ but it seems crude since good barometers for ugliness are lacking. Assuming mandatory controls are better than a laissez faire approach, specification standards for signs are needed to simplify administration. ${ }^{318}$ These standards should apply uniformly and usually also retrospectively in light of the low cost of removing or modifying existing signs.

\section{Conclusion}

The most prevalent systems of land use control in the United States are neither as efficient nor as equitable as available alternatives. Detailed mandatory zoning standards inevitably impair efficient urban growth and discriminate against migrants, lower classes, and landowners with little political influence. The elimination of all mandatory zoning controls on population densities, land use locations, and building bulks is therefore probably desirable. The alternative proposed in this article relies primarily on a variety of less centralized devices to internalize the external costs of unneighborly land use activities; a brief summary of the proposal will highlight its content.

Consensual systems of internalization - the merger of adjoining land parcels and covenants between their owners-are good mechanisms for handling external costs, particularly in areas where much of the land is still undeveloped. In all locations the wish of landowners to show good manners to their neighbors, essentially a consensual system, operates to limit the incidence of nuisances. Although these voluntary

\footnotetext{
316 In established subdivisions special assessments can raise the revenues needed for compliance with the standards.

317 The index for fines on signs could be based on variables like brightness, area, height, or movement. California State Senator Beilenson has proposed an annual tax of fifty cents per square foot of display area on outdoor signs more than 100 feet away from the premises to which they relate. This tax would be uniform throughout California and independent of the height, brightness, or movement of the sign. See Calif. S.B. 708 (1972).

318 Keying standards to street width and speed limits seems appropriate. For model standards of this sort, see W. Ewald, JR., \& D. Mandelker, Street Graphics 70-79, 85-105 (1971).
} 
mechanisms should be strengthened, more coercive devices to discourage unneighborly behavior are also needed. ${ }^{319}$ Since current nuisance law is in disarray, a large part of the analysis was devoted to developing an efficient and fair set of nuisance rules. It was suggested that substantial injuries from nuisances be internalized through private lawsuits by the injured neighbors; a plaintiff entitled to a remedy would be able to choose between collecting damages and purchasing the termination of the nuisance at the objective cost of that termination to the nuisance maker.

Pervasive but individually trivial harms caused by noxious land uses cannot be efficiently internalized through nuisance suits. These external costs can best be deterred through: (1) fines, often graduated by geographic area, levied against the pervasive damage of nuisances that offer a reasonably stable objective index of noxiousness and (2) selected uniform mandatory standards applicable to the pervasive nuisances that do not present such an index. These fines and mandatory standards should generally apply to both existing and prospective land uses to assure equal treatment of landowners and to create political pressures against excessively strict fines or standards. These internalization devices could be administered by metropolitan Nuisance Boards that would perform rule making, administrative, and adjudicatory functions within the guidelines of state law.

The proposed approach is superior to zoning in achieving the fundamental goals of a land use control system-efficiency and equity. Greater reliance on decentralized internalization devices reduces the potential for high prevention costs inherent in centralized approaches. Although the administrative costs of the proposed combination of remedies might be greater than in a system relying heavily on zoning controls, that difference is likely to be more than compensated for by allocative efficiencies. To assure equity, arbitrary geographic zones for standards that are too elusive for effective judicial review should be avoided; extensive use of zones has resulted in the serious amounts of graft and discrimination that now plague zoning. Finally, elimination of mandatory population density controls can correct the regressive distributional effects of existing zoning controls.

The recommendations in this article may seem drastic. Houston, however, has prospered even though it provides considerably fewer internalization devices than suggested here. ${ }^{320}$ In that city restrictive

319 Siegan would perhaps disagree. See generally B. SIEgAN, LaND UsE Wrthout Zoning (1972).

320 Neither nuisance law nor fines are important in Houston. 
covenants have adequately protected many fine residential areas. ${ }^{321}$ Certain aspects of Houston's landscape, however, suggest that a completely laissez faire distribution of property rights is not the best approach; people in some metropolitan areas would strongly disapprove of the number of billboards in Houston.

Finally, a word of caution. Most of the proposals in this article have been based on intuitive estimates of the allocative and distributional impacts of alternative internalization systems. Empirical knowledge about these phenomena is limited, in large part because few major variants of land use control systems have been attempted in the United States. The Department of Housing and Urban Development has recently had available for the first time substantial funds for urban research; $; 22$ some of these funds could be used to finance state and local experimentation with new varieties of land use controls. Without more experimentation future governmental interventions in land use markets will continue to be potentially destructive. Unfortunately, the current trend seems to be toward stricter mandatory controls. Zoning is today out of control and must be severely curtailed, if not entirely replaced.

321 Houston has no use controls and no significant density restrictions. The subdivision ordinance requires that new buildings have twenty-five foot front yard setbacks. A parking ordinance requires that new residential projects provide one or more parking spaces per dwelling unit, depending on the number of bedrooms. The Houston building code also contains some provisions regulating the distance between buildings. Siegan, NonZoning, supra note 2, at 75-76. For a mixture of views on the appearance of Houston, see 136 Architectural Forum, April, 1972, at 24-39.

322 In the early seventies HUD has been awarded annual appropriations of about $\$ 50$ million for research and technology, three or four times the level of appropriations in the late sixties. 